\title{
ESTUDO DA EVOLUÇÃO CARIOTÍPICA DO GÊNERO CROTALARIA L. (LEGUMINOSAE-PAPILIONOIDEAE) COM O EMPREGO DE TÉCNICAS DE BANDAMENTO CROMOSSÔMICO E HIBRIDAÇÃO IN SITU FLUORESCENTE (FISH)
}

\author{
MATEUS MONDIN \\ Engenheiro Agrônomo \\ Orientadora: Profa. Dra. MARGARIDA L.R. DE AGUIAR-PERECIN \\ Tese apresentada à Escola Superior de Agricultura \\ "Luiz de Queiroz", Universidade de São Paulo, \\ para obtenção do título de Doutor em Agronomia, \\ Área de Concentração: Genética e Melhoramento \\ de Plantas
}

\author{
PIR A C I C A B A \\ Estado de São Paulo - Brasil \\ Agosto - 2003
}




\section{Dados Internacionais de Catalogação na Publicação (CIP) DIVISÃO DE BIBLIOTECA E DOCUMENTAÇÃO - ESALQ/USP}

Mondin, Mateus

Estudo da evolução cariotipica do gênero Crotalaria L. (Leguminosae-

Papilionoideae) com o emprego de técnicas de bandamento cromossômico e hibridação in situ fluorescente (Fish) / Mateus Mondin. - - Piracicaba, 2003.

115 p. : il.

Tese (doutorado) - Escola Superior de Agricultura Luiz de Queiroz, 2003. Bibliografia.

1. Bandamento cromossômico 2. Cariótipo 3. Crotalária 4. Citogenética molecular 5. Citogenética vegetal I. Titulo

CDD 633.562

"Permitida a cópia total ou parcial deste documento, desde que citada a fonte - O autor" 
Em homenagem ao:

\section{Prof. Paulo Guilherme Victório Valeri, Biólogo}

Dedicado à minha família:

Magda Elizabeth, esposa amada e paciente

Gabriel, filho querido e paciente

Giovanni, filho renovador

Sebastiano, meu pai

Isterlina, minha mãe

Marcos, Samuel e Raquel Mondin, meus irmãos

Maria Julia, minha sobrinha

Talita, minha cunhadinha

"Graças te dou, ó Pai, Senhor do céu e da terra, que ocultaste estas coisas aos sábios e entendidos, e revelaste aos pequeninos." Mateus 11:25 


\section{AGRADECIMENTOS}

A Profa. Dra. Margarida Lopes Rodrigues de Aguiar-Perecin, que praticamente me adotou com apenas 17 anos para fazer parte de sua equipe, guiando me pelo conhecimento e passando sua experiência de mestre para discípulo durante esses 10 anos que passei em seu laboratório.

A FAPESP pela bolsa de estudos concedida para realização deste estudo e pelo seu patrocínio ao projeto Temático do qual este estudo fez parte.

Ao Departamento de Genética pela estrutura que me permitiu crescer como homem e profissional.

Aos professores por todo ensinamento e paciência que tiveram comigo.

Aos alicerces de minha carreira, "os quatro de Ithaca", Profs. Drs. Mônica Rosa Bertão - UNESP/Assis, Janay Almeida dos Santos-Serejo - EMBRAPA/Fruticultura, José Raulindo Gardingo - Universidade Estadual de Ponta Grossa/PR e Angélica Martinho Ferreira - Univesidade Estadual do Mato Grosso do Sul/MS.

Aos técnicos Silvia Cristina Menuzo Molina e Carlos Alberto Veríssimo, verdadeiros heróis.

A Profa. Dra. Maria Lúcia Cameiro Vieira, pela confiança, amizade e ensinamentos e ainda por estar disposta a me ouvir quando mais precisei.

Aos Profs. Drs. Paulo Maurício Ruas e Claudete de Fátima Ruas da Universidade Estadual de Londrina - PR, pela amizade, pelos conselhos e pelas discussões ao longo deste projeto.

Ao Prof. Dr. Giancarlo Xavier de Oliveira, por estar sempre aberto as discussões e desabafos.

Ao meu querido irmão, filho e amigo Prof. Dr. Marco Aurélio Neves da Silva, pelo convívio, confiança, amizade nestes longos anos de ESALQ. 
A um dos maiores incentivadores da minha carreira Prof. Dr. Mauro Mondin Universidade Federal do Mato Grosso, não preciso dizer muito apenas que o amo.

Aos Profs. Reginaldo, Maurides, Nil, Márcio, Jorge e Digo, doutores em vida e amizade.

Ao meu grande amigo e companheiro Eng. Agr. Gustavo Franco Rosa Vieria.

A todo o pessoal da $\mathrm{ABU}$, pela força que deram ao longo destes 10 anos de ESALQ.

Em especial a família de Donald W. Caulkins e Chandler (Xed) seu filho por tudo que fizeram por mim e minha família.

Ao Dr. Joaquim Antonio Machado - Syngenta, pela amizade, conselhos, apoio, conversas e projetos.

Aos profissionais e funcionários de campo por manterem os plantios de Crotalaria sempre perfeitos

Aos seguintes colegas pela direta contribuição no trabalho: Prof. Dr. Eduardo Leonardecz - UCB, Dra. Alessandra Pereira Fávero - EMBRAPA/Cernagem, Prof. Dr. Rodrigo Rodrigues Matiello - UEPG, Dra. Caroline Moor Wagner - EMBAPA/RS, Dr. Lafayete Luiz da Silva - Sakata Seed Sudamerica, Dr. Vanoli Fronza - EPAMIG, M.Sc. Heiko Hossman - Naural Soluções Setoriais, Profa. Dra. Monalisa Sampaio Cameiro UFG, M.Sc. Marisa, Dr. Renato Rodrigues Ferreira, Dr. Ricardo Francisco Fornazier, Dr. Guilherme José Gonçalves Pereira, M.Sc. Glauce Cristina Rumin, Karina Martins e Carolina Vianna Morgante.

A todos os colegas do curso de pós-graduação em Genética e Melhoramento de Plantas do período de 1994 a 2003, meus sinceros agradecimentos pelo convívio e paciência em especial ao pessoal do PFC na pessoa do seu presidente Francisco J. C. Farias e pelo colega Vanderlei S. Santos.

A escola de inglês Communication Academy of Language (atual Centro Cultural Americano) na pessoa da sua diretora Virginia pela vitória que vocês tiveram em me ensinarem algumas coisa desta língua e também por terem tolerado meus atrasos nos pagamentos das mensalidades. 
Aos funcionários do Departamento de Genética, a todos meus sinceros agradecimentos, muitos amigos, mas todos tornam a nossa passagem mais fácil e agradável pelo curso.

Aos membros desta banca, desde já pela disposição em ler este estudo e pelas críticas que contribuirão muito nas publicações 


\section{SUMÁRIO}

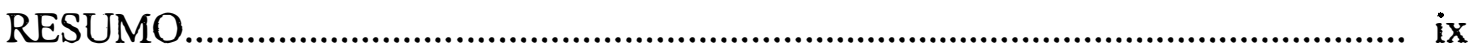

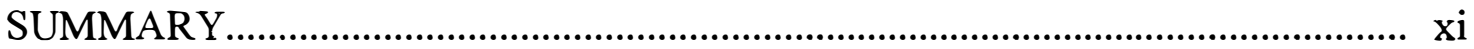

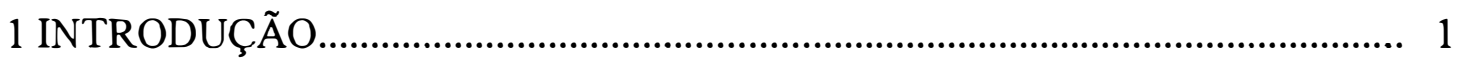

2 REVISÃO DE LITERATURA........................................................................ 4

2.10 gênero Crotalaria ........................................................................................ 4

2.2 Citogenética do gênero Crotalaria..................................................................... 7

2.3 Estrutura dos cromossomos de espécies da família Leguminosae-

Papilionoideae..................................................................................................... 20

2.3.1 Bandamento-C em espécies da família Leguminosae..................................... 20

2.3.2 Coloração com fluorocromos e natureza dos blocos heterocromáticos............... 22

2.3.3 Hibridação molecular in situ e o mapeamento físico de seqüências

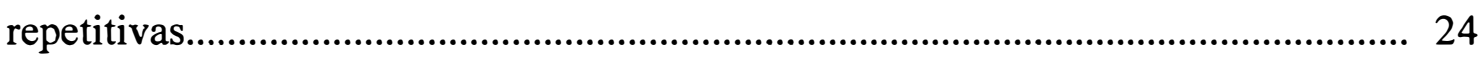

3 MATERIAL E MÉTODOS...................................................................... 31

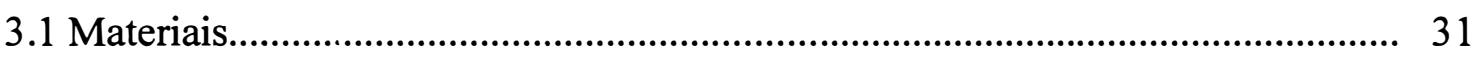

3.2 Germinação

3.3 Pré-tratamento com inibidores do fuso mitótico................................................ 32

3.4 Preparação de lâminas......................................................................................... 33

3.5 Coloração pelo método de Feulgen.............................................................. 34

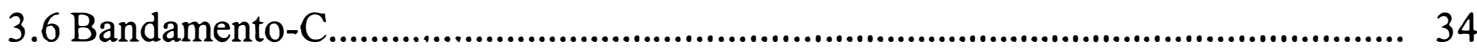

3.7 Coloração com fluorocromos........................................................................... 35

3.7.1 Coloração com DAPI (4'-6'-diamidino-2-fenilindol)........................................ 35

3.7.2 Coloraçãocom DAPI/AMD (4'-6'-diamidino-2-fenilindol/Actinomicina D)... 35

3.7.3 Coloração com CMA (Cromomicina $A_{3}$ ).......................................................... 36

3.7.4 Coloração com CMA/DA (Cromomicina $\mathrm{A}_{3}$ /Distamicina)................................ 36

3.7.5 Coloração seqüencial....................................................................................... 36 
3.7.5.1 Coloração sequüencial com CMA - CMA/DA..................................... 36

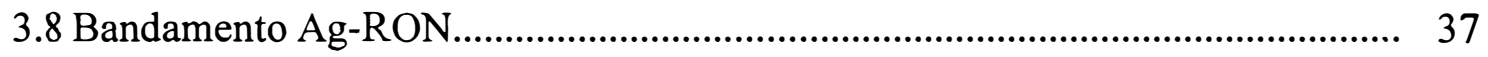

3.9 Hibridação in situ fluorescente (FISH) ...................................................... 38

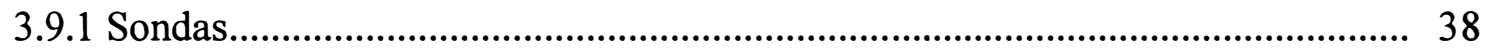

3.9.1.1 Extração de DNA genômico total de espécies de Crotalaria pelo método do CTAB 38

3.9.1.2 Amplificação do gene de RNA ribossômico de 5S...................................... 39

3.9.2 Hibridação molecular in situ de sondas de DNA ribossomais de 45S e 5S..... 41

3.12 Microscopia e análise de imagens................................................................ 42

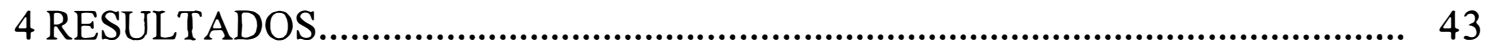

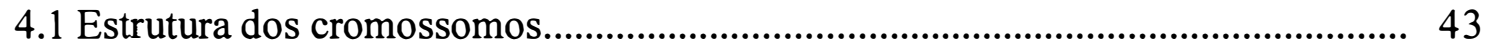

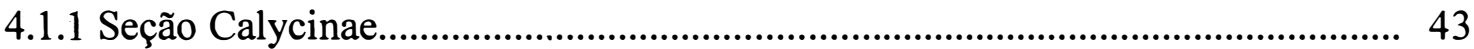

4.1.1.1 Crotalaria juncea................................................................................. 43

4.1.1.2 Crotalaria stipularia............................................................................. 45

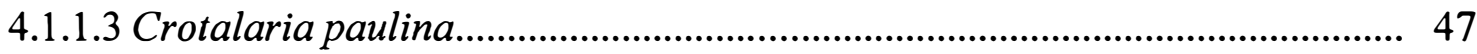

4.1.2 Seção Crotalaria, Sub-seção Crotalaria.......................................................... 48

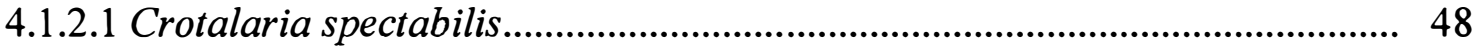

4.1.3 Seção Chrysocalycinae, Sub-seção Incanae................................................. 50

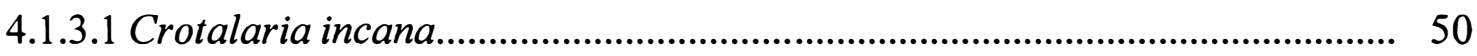

4.2 Marcadores cromossômicos e a subdivisão do gênero Crotalaria em seções....... 53

5 DISCUSS ÃO

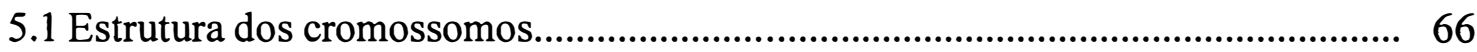

5.2 Evolução dos cariótipos e sua concordância com a taximetria do gênero

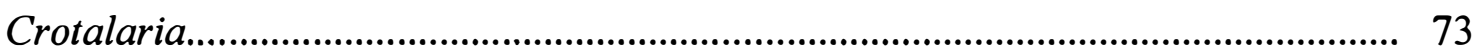

5.3 Origem e evolução de espécies alopoliplóides................................................. 77

6 CONCLUSÃO............................................................................................. 83

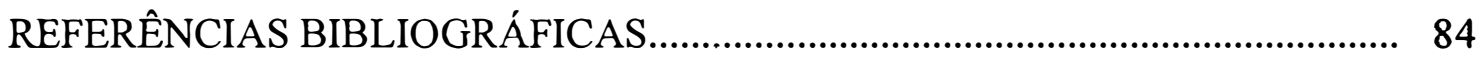

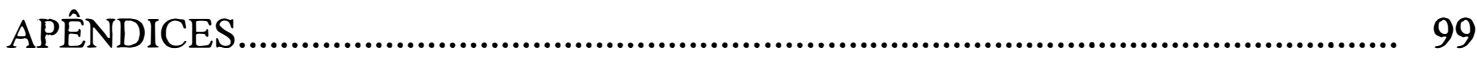




\title{
ESTUDO DA EVOLUÇÃO CARIOTÍPICA DO GÊNERO CROTALARIA L. (LEGUMINOSAE-PAPILIONOIDEAE) COM O EMPREGO DE TÉCNICAS DE BANDAMENTO CROMOSSÔMICO E HIBRIDAÇÃO IN SITU FLUORESCENTE (FISH)
}

\author{
Autor: MATEUS MONDIN \\ Orientadora: Profa. Dra. MARGARIDA L.R. DE AGUIAR-PERECIN
}

\section{RESUMO}

O gênero Crotalaria é um dos maiores da familia Leguminosae, com mais de 550 espécies descritas. $\mathrm{O}$ gênero está dividido em 8 segões botânicas de acordo com caracteristicas morfológicas, especialmente da flor. Algumas espécies de Crotalaria são de importância agrícola, sendo as mais importantes, $C$. juncea, $C$. paulina, $C$. stipularia e $C$. spectabilis, respectivamente. Estas espécies são utilizadas principalmente na adubação verde, produção de papel fino e condal A maioria das espécies descritas possuem $2 n=16$, com poucas espécies com $2 n=14$ e os poliplóides são múltiplos destes números. Com base nestas observações, dois números básicos têm sido propostos para o grupo, $x=8$ e $x=7$. Além disso, um número muito restrito de espécies possui cariótipos precisamente descritos e nenhuma técnica moderna de citogenética que permita uma diferenciafão linear dos cromossomos foi aplicada em espécies do gênero Crotalaria. Foram analisadas cinco espécies: Crotalaria juncea $(2 \mathrm{n}=16)$, . . stipularia $(2 \mathrm{n}=32)$, C. paulina $(2 \mathrm{n}=32)$ da seção Calycinae, $C$. spectabilis $(2 \mathrm{n}=16)$ da seção Crotalania e $C$. incana $(2 \mathrm{n}=14)$ da seção Chrysocalycinae. A aplicacão de metodologias de bandamento-C, coloração com os fluorocromos cromomicina $\mathrm{A}_{3}$ (CMA) e 2'-4'-diamidino-2-fenilindol (DAPI) e hibridação in situ fluorescente (FISH) permitiu a caracterização de importantes marcadores cromossômicos para estudos da evolução dos cariótipos. As espécies que pertencem às seçōes Calycinae e Crotalaria possuem 
bandas- $\mathrm{C}$ pericentroméricas, $\mathrm{CMA}$ positivas e portanto ricas em $\mathrm{GC}$, e bandas- $\mathrm{C}$ correspondentes às heterocromatinas adjacentes à constrição secundária, que fluorescem mais intensamente com a combinação CMA e distamicina (DA), revelando-se altamente ricas em GC. Na espécie $C$. incana, não foram identificadas bandas-C pela metodologia utilizada, entretanto bandas DAPI positivas muito tênues foram identificadas, bem como quatro bandas ricas em GC, sendo uma destas relacionada ao rDNA $45 \mathrm{~S}$ e outra ao $5 \mathrm{~S}$ e as duas restantes sem relações com rDNAs. $\mathrm{O}$ emprego da FISH com a utilizaçåo de sondas de rRNAs 18S-5.8S-26S e 5S, mostrou sinais que correspondem às regiões muito ricas em GC. Foi detectado apenas um sinal de FISH comespondente ao rDNA 5S no cromossomo 1 de $C$. juncea e $C$. spectabilis, e no cromossomo 3 de $C$. incana. Sinais de rDNA 45S foram identificados na constrição secundária e regiões heterocromáticas adjacentes, localizadas no cromossomo 1, em todas as espécies analisadas. Adicionalmente em $C$. juncea da seção Calycinae, foi observado um sítio de rDNA 45S em um cromossomo identificado como par 4. Nas espécies poliplóides não se identificou um número múltiplo de sinais de rDNA 45S, além do sítio de rDNA conespondente à constrição secundária foram detectados mais dois sítios em $C$. paulina e em $C$. stipularia mais um sítio. Em $C$. incana observou-se um loco maior de rDNA no cromossomo 1 e dois menores nos cromossomos 4 e 5 , sendo que estes dois últimos, pelo seu tarnanho diminuto não puderam ser identificados pela coloração CMA/DA. Somente C. spectabilis apresentou um único sinal do rDNA de 45S, correspondendo à região organizadora do nucléolo (RON) e heterocromatinas adjacentes. Estes resultados sugerem que as espécies poliplóides perderam locos de rDNA de $45 \mathrm{~S}$ em um dos cromossomos homeólogos do cromossomo 4 em C. paulina e dois cromossomos homeólogos em C. stipularia, sendo um correpondente ao cromossomo 1 e outro ao 4 de $C$. juncea. Além disso, os dados indicam uma tendência geral de evolução dos genomas destas espécies. Sugere-se que durante a evolução houve ganho e/ou perda de seqüências ricas em AT e GC. Se considerarmos $\mathrm{x}=7$ como número básico derivado de $\mathrm{x}=8$, além de ocorrência de rearranjos cromossômicos, teria ocorrido ganho de seqüências repetitivas ricas em AT. Alterações de seqüências ricas em GC são evidentes principalmente nos poliplóides, onde ocorreu perda de sítios de rDNA 45S, bem como outros tipos de seqüências não estudadas no presente trabalho, mas que se pode inferir pelo tamanho menor dos cromossomos dos poliplóides. 


\title{
KARYOTYPIC EVOLUTION STUDY OF THE GENUS CROTALARIA L. BY CHROMOSOMAL BANDING PROCEDURES AND FLUORESCENT IN SITU HYBRIDIZATION (FISH)
}

\author{
Author: MATEUS MONDIN \\ Adviser: Prof. Dr. MARGARIDA L.R. DE AGUIAR-PERECIN
}

\section{SUMMARY}

Crotalaria is one of the largest genus in the family Leguminosae, with more than 550 species described. The genus comprises eigth botanic sections based on morphological characters, specially flower features. The genus Crotalaria includes some crops, such as $C$. juncea, $C$. paulina, $C \cdot$ stiplularia and $C$. spectabilis. The main crop is $C$. juncea, sunnhemp, used for fine paper and cordage production, and green manure. Most of the species described have $2 n=16$, and few species have $2 n=14$ or are polyploids with somatic numbers which are multiples of these numbers. Based on these observations about chromosome numbers there are two basic numbers proposed to the group, $x=8$ and $x=7$. Moreover, a restricted number of species have their karyotypes precisely described and no modern cytogenetic techniques have been applied to Crotalaria, then, features of linear differentiation of the chromosomes are unknown.

Five species were investigated: $C$. juncea $(2 \mathrm{n}=16), C$. stipularia $(2 \mathrm{n}=32)$ and $C$. paulina $(2 \mathrm{n}=32)$ of the section Calycinae, C. spectabilis $(2 \mathrm{n}=16)$ of the section Crotalaria and $C$. incana $(2 \mathrm{n}=14)$ of the section Chrysocalycinae. The application of Cbanding, fluorochrome banding with chromomycin $A_{3}$ and 2'-4'-diamidino-2phenylindole (DAPI) and fluorescent in situ hybridization (FISH) procedures allowed the characterization chromosomal markers, very important for karyotype evolution 
studies. The species belonging to sections Calycinae and Crotalaria - subsection Crotalaria have pericentromeric C-bands, CMA positive and thus GC-rich, and C-bands corresponding to secondary constriction adjacent heterochromatins, highly GC-rich by the combination $\mathrm{CMA} /$ distamycin (DA). In the $C$. incana no $\mathrm{C}$-bands could not be differentiated by the procedure used, however many thin DAPI bands were identified, as well as four GC-rich regions, being one corresponding to secondary constriction adjacent heterochromatin, another with 5S rDNA and two not related to rDNAs. FISH of probes $45 \mathrm{~S}$ and $5 \mathrm{~S}$ rDNAs showed signals corresponding to highly GC-rich regions. Only one signal of FISH using 5S rDNA probes was detected in chromosome 1 of $C$. juncea and $C$. spectabilis, and chromosome 3 of $C$. incana. A FISH signal correspondent to $45 \mathrm{~S}$ rDNA loci were identified at the secondary constriction and adjacent heterochromatic blocks in the chromosome 1 of all the species analysed. Additionally a $45 \mathrm{~S}$ rDNA site was observed in a chromosome identified as pair 4 in $C$. juncea. In the polyploid species a multiple number of $45 \mathrm{~S}$ rDNA signal were not identified. Additionally to the signal on chromosome 1, two sites were observed in C. paulina and one in C. stipularia. In $C$. incana the major 45S rDNA locus in chromosome 1 and two minor ones in chromosomes 4 and 5 were revealed. Only $C$. spectabilis presented one $45 \mathrm{~S}$ rDNA locus. These results suggest that the polyploid species lose $45 \mathrm{~S}$ rDNA loci in one of the homeologues of chromosome 4 of the ancestral species similar to $C$. juncea in C. paulina, and in two chromosomes corresponding to pairs 1 and 4 of such ancestral. The results suggest some trends during genome evolution of these species, such as gain and/or loss of AT and GC-rich sequences. If one considers $\mathrm{x}=7$ as a basic numberderived from $x=8$, chromosome rearrangements and gain of At-rich repetitive sequences could have occurred. Changes in GC-rich sequences are evident in polyploids, in which $45 \mathrm{~S}$ rDNA loci were lost, as well as other classes of sequences not studied in the present work, but that the smaller size of the chromosomes of the polyploids seem to evidence. 


\section{INTRODUÇÃO}

O gênero Crotalaria pertence à família Leguminosae, subfamília Papilionoideae, sendo hoje incluído na tribo Crotalarieae. Dentro da família Leguminosae, Crotalaria é o maior gênero e foi relatada a existência de mais de 550 espécies (Polhill, 1982; Lewis, 1987).

(Este gênero possui grande importância na agricultura, sendo utilizado na alimentação humana e animal, para uso médico, ornamental e suas duas maiores aplicações são a fixação do nitrogênio atmosférico, característica da família Leguminosae e a qualidade das suas fibras (Medina, 1959; Polhill, 1982). No Brasil tem-se conduzido vários ensaios com espécies de Crotalaria para uso na produção de fibra e papel. (Medina, 1959; Polhill, 1982).

Apesar da grande importância deste gênero de plantas, poucos estudos citogenéticos têm sido realizados. Assim, a maioria dos trabalhos se restringiram à contagem do número de cromossomos e alguns poucos trabalhos descreveram o cariótipo de algumas espécies (Gupta \& Gupta, 1978a; Raina \& Verma, 1979; Verma et al., 1984; Palomino \& Vázquez, 1991; Oliveira \& Aguiar-Perecin, 1999). Destes estudos ficou estabelecido que o grupo possui um número básico de cromossomos $\mathrm{x}=8(2 \mathrm{n}=16)$. O número básico $\mathrm{x}=7$ também tem sido reportado, baseado na observação de espécies com $2 \mathrm{n}=14$, como em $C$. incana. Há discussões na literatura sugerindo que $x=7$ poderia ter derivado de $x=8$ através de aneuploidia, ou outros rearranjos estruturais envolvendo a perda de centrômeros (veja Palomino e Vázquez, 1991).

Foi realizado no Laboratório de Citologia do Departamento de Genética (ESALQ) uma análise morfométrica do cariótipo de onze espécies com ocorrência no Brasil pertencentes a 4 seções botânicas, utilizando-se coloração convencional 
(Oliveira \& Aguiar-Perecin, 1999). Constatou-se que as espécies diplóides têm $2 \mathrm{n}=16$, com exceção de $C$. incana $(2 \mathrm{n}=14)$, e duas espécies poliplóides têm $2 \mathrm{n}=32$ (C. paulina e C. stipularia). Alguns aspectos foram observados nas espécies investigadas, tais como: a ocorrênica de uma constrição secundária no braço menor do cromossomo 1; a maior parte dos cromossomos são metacêntricos e ocorrem claras diferenças no tamanho dos mesmos entre algumas espécies. Observou-se também nos cariótipos de espécies do gênero Crotalaria, uma variação gradativa do tamanho dos cromossomos, sendo a diferença entre o maior e o menor par ao redor de 1,5-1,7 vezes (Oliveira, 1992; Oliveira \& Aguiar-Perecin, 1999). Nas espécies diplóides, o valor estimado para o tamanho total do lote haplóide (soma do comprimento dos cromossomos) variou de $11,10 \mu \mathrm{m}$ em $C$. virgulata grantiana $(2 n=16)$ a $19,25 \mu \mathrm{m}$ em $C$. incana $(2 n=14)$. Na seção Calycinae, os valores estimados do lote haplóide foram de $19,56 \mu \mathrm{m}$ em $C$. juncea $(2 \mathrm{n}=16)$, enquanto que em $C$. paulina foi de $31,15 \mu \mathrm{m}$ e em C. stipularia $29,04 \mu \mathrm{m}$, ambas com $2 \mathrm{n}=32$ (Oliveira, 1992). Nas espécies tetraplóides os cromossomos são, portanto, menores em relação às espécies diplóides. Estas diferenças de medidas de comprimento cromossômico podem refletir diferenças no conteúdo de DNA. Na família Leguminosae tem sido constatada enorme variabilidade do valor-C de DNA, por exemplo cerca de $27 \mathrm{pg}$ em Vicia faba e 0,9 pg em Vigna lancifolia. Esta variabilidade é devida em grande parte a diferenças no conteúdo de seqüências repetitivas (revisão em Bennett \& Leitch, 1995; Bennett \& Leitch, 1997).

Muitas são as metodologias para se estudar as seqüências repetitivas, entre as quais destacam-se aquelas que localizam tais seqüências em determinadas regiões dos cromossomos, sendo úteis para estudos de evolução e na identificação de cromossomos individuais (Galasso et al., 1995). Entre as metodologias utilizadas destacam-se o bandamento- $\mathrm{C}$, que localiza regiões heterocromáticas constitutivas e a coloração com fluorocromos específicos para regiões ricas em GC ou AT, ou seja, que qualificam o tipo de seqüência que compõem uma determinada região heterocromática, técnicas estas muito utilizadas durante as décadas de 1970 e 1980 (para revisão veja Friebe et al., 1996). A partir do desenvolvimento de sondas frias, 
ou seja, não-radioativas, a hibridação fluorescente in situ (FISH) tem se destacado no estudo da evolução de cariótipos através do mapeamento físico de seqüências repetitivas, principalmente dos genes ribossomais $45 \mathrm{~S}$ e $5 \mathrm{~S}$, e também no estudo da organização molecular dos cromossomos utilizando-se como sondas outras seqüências repetitivas em tandem ou dispersas, assim como sondas específicas de telômero e centrômeros (Heslop-Harrison, 2000).

Dentro deste contexto, em cinco espécies do gênero Crotalaria, pertencentes a três seções botânicas distintas, que tiveram seus cariótipos estudados previamente por Oliveira \& Aguiar-Perecin (1999), foram caracterizados os padrões de bandamento- $\mathrm{C}$, e de bandas reveladas por fluorocromos, bem como foi feito o mapeamento dos genes ribossomais (rDNAs) $45 \mathrm{~S}$ e $5 \mathrm{~S}$ através de hibridação molecular fluorescente in situ (FISH). Os resultados obtidos através destas técnicas permitiram um estudo detalhado sobre a estrutura dos cromossomos das espécies do gênero Crotalaria, bem como serviram como marcadores para o entendimento da evolução cariotípica do gênero. 


\section{REVISÃO DE LITERATURA}

\subsection{O gênero Crotalaria}

A família Leguminosae compreende cerca de 650 gêneros, com 18000 espécies, o que a torna a terceira família em número de espécies após Asteraceae e Orchidaceae. Destas 18000 espécies, um terço estão contidas em seis gêneros: Acácia, Astragalus, Cássia, Crotalaria, Indigofera e Mimosa (Polhill et al., 1981).

Portanto o gênero Crotalaria aparece em posição de destaque dentro da família. Entretanto, para um melhor entendimento da posição do gênero dentro da família, é interessante rever a taxonomia das leguminosas. A família Leguminosae está subdividida em três subfamílias: Mimosoideae, Cesalpineoideae e Papilionoideae, sendo que nesta última encontra-se o gênero Crotalaria, juntamente com outras espécies mais conhecidas tal como os feijões (Phaseolus, Vicia e Vigna), lentilha (Lens), grão-de-bico (Cicer), soja (Glycine) e ervilha (Pisum), embora pertençam a tribos diferentes (Polhill \& Raven, 1981). Leguminosae/Papilionaceae, Papilionoideae são os nomes tradicionamenlte utilizados pelas publicações do Kew Royal Botanic Garden - UK, e estão de acordo com a classificação proposta para as leguminosas. Alternativamente, os nomes Fabaceae e Faboidae são também amplamente utilizados (Polhill \& Raven, 1981).

O uso de Papilionoideae é entendido como legítimo pelo Artigo 18 do código de classificação de plantas leguminosas, o qual especificamente sanciona Papilionaceae, mas no prefácio está previsto que onde o uso de Papilionaceae torna duvidosa uma determinada classificação taxonômica, pode-se utilizar Papilionoideae, desde que as dúvidas de classificação estejam expressas (Polhill \& Raven, 1981). Entretanto, Isaly e Polhill (1980, citados por Polhill \& Raven, 1981) submeteram para o código o pedido de 
sancionamento da continuidade do uso de Papilionoideae e desde então esta designação tem sido aceita.

O gênero Crotalaria e espécies aparentadas estão incluídas na tribo Crotalarieae. Esta tribo foi criada após uma revisão em toda a subfamília Papilionoideae, e concluiu-se que apesar de algumas sobreposições com as espécies da tribo Genisteae, as afinidades eram incertas (Polhill, 1976; Polhill, 1981).

Tem-se considerado que o principal centro de diversificação está no centro sul e leste da África, mas com extensões através do oceano Atlântico, bem como para a Ásia e Austrália, com considerável diversificação fora da África (Polhill, 1981). A maior diversidade de espécies é encontrada no leste e sul da África, do mesmo modo que as espécies filogenéticamente mais relacionadas (Polhill, 1982). Algumas características de Crotalaria são encontradas em Lebeckia, um gênero com aproximadamente 40 espécies concentradas no sul da África (Polhill, 1982). As espécies Aspalathus, Rafnia e Wiborgia, também ocorrem nesta mesma região, pertencem à mesma tribo, entretanto são mais aparentadas com Lebeckia (Polhill, 1982). A classificação das espécies de Crotalaria tem se baseado principalmente em caracteres florais e difere destes gêneros pelo estilete conter pêlos em duas fileiras em espiral e por anteras claramente diferenciadas em cinco dorso fixas curtas e cinco base fixas longas. Segundo (Polhill, 1982), outras características mais obvias, como a quilha rostrada e o legume inflado são úteis para o reconhecimento, mas não para uma classificação precisa, sendo estas características as maiores responsáveis por classificações errôneas de um grande número de espécies.

Milne-Redhead (1961) e Polhill (1968) trabalharam na taxonomia de espécies de Crotalaria da África. Destes trabalhos foram delimitadas 432 espécies, divididas em onze seções botânicas. Esta divisão foi toda baseada em características florais. A base atual de classificação é o resultado de estudos taximétricos realizados por Bisby (1970), Bisby (1973) e Bisby \& Polhill (1973). Os estudos taximétricos reduziram o número de seções para apenas oito. Além disso o gênero pode ser dividido em duas partes dependendo da complexidade floral relativa da espécie (Bisby \& Polhill, 1973). 
Aproximadamente metade do gênero possui flores não especializadas, o restante, incluindo parcialmente duas seções de transição, possuem flores especializadas, nas quais o cálice é prolongado na face ventral e bilabiado, os apêndices padrões, estruturas que dão suporte ao cálice, são mais piramidais ou lameliformes e restritos ao limbo, o rostro da quilha é usualmente torcido e o estilete tem pêlos em uma linha espiral, ou em ambos os lados (Polhill, 1982). Estas características parecem estar relacionadas com a transferência mais eficiente do grão de pólen, o qual é derrubado dentro da quilha antes da abertura completa da flor e é expulso no cabelo do estilete por uma ação de pistão, quando a quilha é pressionada pelo polinizador, que procura o néctar da base do cálice (Bisby \& Polhil, 1973; Polhill, 1982). Entretanto as características não especializadas não deixam de existir como um todo nas diferentes seções, as características especializadas em nenhum grau de combinação são únicas (Polhill, 1982). A combinação de caracteres são usualmente constantes nas espécies e são freqüentemente correlacionados, existindo as vezes variação independente e estados intermediários ocorrem (Bisby \& Polhill, 1973).

Muito disto é o resultado de uma evolução convergente, com um número de estado de caracteres tendo evoluído muitas vezes (Bisby \& Polhill, 1973). A dificuldade de se classificar Crotalaria, vem do grande número de espécies e da natureza reticulada da variação interespecífica: muitos caracteres variam, mas os diferentes estados estão combinados de muitos modos que dificulta definir o tamanho natural dos grupos (Bisby, 1970; Bisby \& Polhill, 1973; Polhill, 1982).

A mistura de flores especializadas e não especializadas criam ligações entre as subseções. Segundo Bisby \& Polhill (1973) o grupo poderia ser subdividido em dois subgêneros: o primeiro contendo as seções Grandiflorae, Chrysocalycinae, Hedriocarpae, e Geniculatae; e o segundo contendo Calycinae, Crotalaria e Dispermae (Bisby \& Polhill, 1973), entretanto, o gênero não é subdividido por existirem muitos grupos intermediários de espécies fora da África, principlamente entre a seção Calycinae e Crotalaria, da Índia. As espécies menos especializadas têm uma distribuição anfiatlântica, a maioria na América do Sul, partindo do sul da África. A grande diversidade ocorreu na África e Madagascar, mas existem centros secundários na Índia 
com flores mais especializadas, de onde muitos grupos podem ter seguido para Austrália e para o oeste do Novo Mundo (Bisby \& Polhill, 1973).

\subsection{Citogenética do gênero Crotalaria}

$\mathrm{O}$ número básico $\mathrm{x}=9$ tem sido proposto para a tribo Crotalarieae e foi encontrado nos gêneros Lebeckia, Wiborgia, Aspalathus, Bolusia, Lotononis, Melolobium e Aspalathus, ainda são descritos os número x=8 e 7 (Goldblatt, 1981). O número básico $\mathrm{x}=7$, tem sido descrito para Pearsonia e Rothia, $\mathrm{x}=12$ para Anathrophyllum e $\mathrm{x}=8$ tem sido considerado número básico de Rafnia e Crotalaria (Goldblatt, 1981).

Todos os trabalhos sobre contagem do número de cromossomos e descrição de cariótipos dentro do gênero Crotalaria, foram realizados utilizando-se coloração convencional de microsporócitos ou de pontas de raízes tratadas ou não com inibidores do fuso mitótico.

Um dos primeiros estudos sobre o número de cromossomos no gênero Crotalaria, foi realizado por Senn (1938, citado por Atchinson, 1950). O principal objetivo deste autor era entender a origem e o número básico de cromossomos de toda a família Leguminosae. Entretando, Senn fez observações significantes para o gênero Crotalaria. A primeira de que a maioria das espécies possuía número básico de cromossomos de $\mathrm{x}=8$, em que somente algumas espécies possuíam $\mathrm{x}=7$. Atchinson (1950) relata que Senn sugere, que o número básico $x=7$ teria se originado ou por aneuploidia, ou por translocações envolvendo a perda de um centrômero, mecanismo este claramente detalhado por Stebbins (1971).

Desde o trabalho de Senn (1938), poucos foram os trabalhos que contribuíram de modo significativo para o entendimento da citogenética do gênero Crotalaria. Atchinson (1950) sugere os mesmos mecanismos descritos por Senn para explicar o número de cromossomos de $C$. incana $(2 \mathrm{n}=14)$. Este mesmo mecanismo será descrito várias vezes por outros autores para explicar a mesma espécies, como veremos a seguir.

Atchinson (1950), entretanto, contribuiu de modo significativo com duas informações não abordadas por Senn (1938). A primeira é de que os cromossomos de $C$. 
incana são um pouco maiores do que a maioria das espécies com $2 \mathrm{n}=16$ cromossomos, enquanto espécies com $2 \mathrm{n}=32$, como $C$. pilosa e C. pumila, apresentam cromossomos relativamente menores. A segunda observação foi a de que os padrões morfológicos e citológicos entre espécies de Crotalaria, indicavam que o gênero é ancestralmente tropical com número diplóide $2 \mathrm{n}=16$. Esta observação suportava as hipóteses botânicas de que o gênero teria sua origem em uma região muito limitada no sul do continente africano (Polhill, 1981; Polhill, 1982).

A década de 1960 pode ser considerada uma fase estacionária para a citogenética do gênero Crotalaria. Os trabalhos deste período observaram um número muito restrito de espécies e utilizaram-se de discussões sobre a citogenética de outras espécies para justificar observações questionáveis.

Datta \& Biswas (1963), Datta \& Ganguly (1967) e Datta \& Ghoshal (1969) descrevem que o número básico de cromossomos é $\mathrm{x}=8$ e que $C$. incana teria número básico de cromossomos $\mathrm{x}=7$ devido a um evento de aneuploidia, tal como foi descrito por Senn (1938). Como tais autores puderam chegar à conclusão de aneuploidia valendo-se da observação e contagem de número somático de cromossomos? Senn valeu-se em muitos casos da observação de cromossomos meióticos, o que poderia lhe dar subsídios para a suposição de aneuploidia.

Datta \& Choudhury (1966) descreveram algumas espécies com cariótipos simétricos e concluíram que estas espécies eram pouco evoluídas. Isto é confirmado posteriormente pelo trabalho de Datta \& Ghoshal (1969) que citam o trabalho de Lewtsky (1931) onde o autor postula que existem duas categorias principais de cariótipos: os simétricos, onde os cromossomos são na sua maioria metacêntricos ou ligeiramente submetacêntricos, e este tipo de cariótipo seria considerado primitivo na natureza; e os assimétricos seriam aqueles cariótipos que não possuem uma uniformidade de tamanho e o centrômero ocuparia posições de submetacêntrico, subtelocêntrico e telocêntrico, sendo estes mais derivados na natureza. Datta \& Ghoshal (1969) aproveitam-se desta discussão para postular que os cromossomos ficaram assimétricos por perdas de material genético em apenas um dos braços cromossômicos e que isto traria vantagens evolutivas, assim algumas espécies de Crotalaria que perderam 
até $50 \%$ do tamanho dos braços menores, representariam espécies intermediárias entre os estágios mais primitivos e os mais avançados na evolução. Entretanto, as observações foram baseadas em um número muito pequeno de espécies, não foi realizada uma correlação dos cariótipos com a posição botânica das espécies estudadas e não havia descrição de espécies assimétricas em Crotalaria.

Estas imperfeições foram corrigidas no trabalho de Boulter et al. (1970), considerados um dos mais relevantes para o entendimento da citogenética do gênero Crotalaria. As espécies estudadas neste trabalho estavam devidamente colocadas em seções botânicas, tal como sugerido por Polhill (1968), o que permitiu aos autores chegarem a uma série de conclusões que até hoje são válidas. Como o trabalho envolveu uma quantidade muito grande de espécies, foi postulado que há uma predominância de espécies com $2 n=16$ cromossomos, mas não há qualquer ressalva de que este seja o número básico. $\mathrm{O}$ trabalho envolveu apenas espécies coletadas na África, levando-se em consideração aquelas introduzidas. Foi descrita apenas uma espécie poliplóide com 2n=32, C. massaiensis (Subseção Macrostachyae), espécie esta sabidamente africana, sendo este o primeiro e único caso até hoje descrito de poliplóidia em uma espécie africana de Crotalaria. Espécies poliplóides ocorrem principalmente no continente americano e as espécies concentram-se principalmente na seção Calycinae (Windler, 1974).

Boulter et al. (1970) fazem quatro observações de maior relevância. A primeira de que cromossomos grandes predominam nas seções Grandiflorae, Incanae (particularmente na Subseção Incanae) e Crotalaria (particularmente na Subseção Crotalaria), sendo a maioria considerada pelo menos como grupos derivados; enquanto cromossomos menores são encontrados geralmente nas seções Crotalaria (particularmente na Subseção Longirostres) e Dispermae, estas consideradas como grupos mais especializados. A segunda observação importante é a de que o tamanho dos cromossomos não parece estar relacionado com nenhum fator geográfico ou ecológico obvio. A terceira observação é a de que a subseção Incanae que é considerada botanicamente como central dentro do gênero, uma vez que compartilha similaridades morfológicas e muitos estados removidos, com a maioria das seções do gênero, possui 
número básico de cromossomos $\mathrm{x}=7$ e não $\mathrm{x}=8$ que é predominante, mesmo na seção botânica a que pertence. A última observação, diz que a última maior série morfológica dentro do gênero é dada pelas duas subseções da seção Crotalaria e a seção Dispermae, as quais formam uma seqüência completamente bem definida de aumento da especialização floral e que o tamanho dos cromossomos decrescem nesta mesma tendência.

Após o trabalho de Boulter et al. (1970), nenhum outro trabalho aborda as espécies divididas em seções pelo menos do ponto de vista de comparação dos cariótipos, a não ser mais recentemente pelos trabalhos de Oliveira (1992) e Oliveira \& Aguiar-Perecin (1999).

Os trabalhos do período das décadas de 1970 e 1980 atêm-se principalmente na descrição detalhada de cariótipos e na observação do comportamento cromossômico na meiose. Contudo, nenhum trabalho arrisca-se em aprofundar as observações de Boulter et al. (1970) e em muitos casos este trabalho nem é citado. Mesmo assim algumas observações importantes foram feitas neste período.

Chennaveeraiah \& Patil (1973) mantêm a discussão de que $C$. incana deva ter sido originada por translocações sem perda de material genético, que a maioria das espécies possuem cromossomos metacêntricos e que por isto os cariótipos são simétricos e conseqüentemente mais primitivos. Entretanto o trabalho traz uma observação interessante de que os genomas das espécies devam ser relacionados, uma vez que as espécies estudadas apresentam apenas um par de cromossomos com constrição secundária. Além disso, Chennaveeraiah \& Patil (1973), relatam que $C$. nitens $(2 \mathrm{n}=32)$ é um poliplóide com grande ocorrência de bivalentes, o que sugere uma homeologia dos genomas. Esta espécie ainda possui dois pares de cromossomos com constrições secundárias, por isso foi sugerido que os ancestrais sejam espécies diplóides do Novo Mundo e devido à sua distribuição geográfica seja de origem recente. Outra observação interessante no trabalho de Chennaveeraiah \& Patil (1973) é a de que não são relatados casos de híbridos naturais ou artificiais entre espécies de Crotalaria, sugerindo-se que alterações cromossômicas representem a grande fonte de especiação. 
Chennaveeraiah \& Patil (1973) estudando espécies das seções Chrysocalycinae, Crotalaria e Calycinae, e também espécies com seções botânicas não definidas e não levando em consideração esta subdivisão em seções botânicas, observaram e concluiram que havia um aumento no tamanho da cromatina que acompanhava o aumento na especialização morfologica. Entretanto, esta observação é questionável, principalmente pelo fato de se comparar espécies de seções botânicas diferentes sem levar este fato em consideração, tal como fez Boulter et al. (1970). Se uma comparação é feita entre espécies das seções Hedriocarpae e Chrysocalycinae consideradas menos especializadas, com espécies das seções Crotalaria (principalmente da subseção Crotalaria) e Calycinae consideradas mais especializadas vemos uma tendência ao aumento de tamanho dos cromossomos nestas duas ultimas seções; a partir do momento que levamos em consideração outras seções como Crotalaria (subseção Longirostres) e Dispermae, que são as seções com o maior grau de especialização morfológica, esta tendência desaparece, pois nestas seções os cromossomos são menores do que aqueles descritos na seção Calycinae e na seção Crotalaria (subseção Crotalaria) e isto já havia sido previsto por Boulter et al. (1970).

Em um estudo clássico sobre espécies de Crotalaria americanas, unifoliadas, Windler (1974) descreveu uma série de espécies com $2 n=16$ e principalmente $2 n=32$ cromossomos. Estas espécies seriam principalmente da seção Calycinae e estariam relacionadas a membros asiáticos desta seção e que possivelmente estas seriam as ancestrais das americanas, embora nenhuma evidência cromossômica tenha sido encontrada. Este trabalho registra claramente a importância da poliploidia durante a evolução de espécies americanas do gênero Crotalaria, sendo que este processo não apresenta importância na África, centro de origem do gênero.

Patil \& Chennaveeraiah (1975) estudando diferente citotipos de $C$. incana e $C$. mucronata, observaram que esta ultima apresentava micronúcleos e que $C$. incana teria surgido por translocações, novamente como proposto por Senn (1938). Patil \& Chennaveeraiah (1975) postulam que o decréscimo por aneuploidia foi acompanhado por um grau de especialização morfológica de $C$. incana, hipótese esta suportada, segundo autores, pelo fato dos três citotipos de $C$. incana apresentarem diferenças 
cromossômicas que estão de acordo com a hipótese de variação morfológica, pois estas variações teriam um valor significante na especiação. Entretanto novamente não são apresentados dados botânicos sobre a espécie e sua posição no gênero e nem sobre a tal "hipótese de variação morfológica". Os autores ainda postulam que $C$. incana tendo especialização morfológica concomitante com aumento do tamanho dos cromossomos exibem o final de linha para tamanho cromossômico (Patil \& Chennaveeraiah, 1975). Dois pontos nesta observação estão corretos, primeiro de que $C$. incana possui alguns apêndices florais que lhe conferem alguma especialidade, mas não a toma especializada, e outro de que sendo uma espécie primitiva no grupo teve mais tempo para se derivar em relação às outras espécies com origem mais recente, sendo assim poderia ser considerada um fim de linha evolutivo.

Neste mesmo período foi publicado o único trabalho sobre conteúdo de DNA em espécies de Crotalaria. Gupta (1976) descreve o conteúdo de DNA de algumas espécies, subdivididas por seções, segundo Bisby \& Polhill (1973). O autor observa que o conteúdo de DNA em $C$. incana é de 3,43 pg, enquanto que em $C$. juncea o conteúdo é de 2,46 pg, indicando perda de material genético com o ganho de características florais especializadas. Gupta ainda ressalta que, entretanto, o maior conteúdo de DNA por área do núcleo foi encontrado em $C$. juncea e que as variações de conteúdo de material nucleolar seria o reflexo do número de repetições do arranjo em tandem das seqüências de DNA ribossômico. Gupta (1976) descreve que espécies de seções diferentes tinham conteúdo de DNA similar, enquanto, espécies pertencentes a seções relacionadas, ou mesmo dentro da mesma seção, diferiam significativamente no conteúdo de DNA. Ainda, estas variações quantitativas no conteúdo de DNA teriam tido um importante envolvimento na evolução do gênero, entretanto mais importante ainda, seria a variação qualitativa do DNA. Gupta (1976) ainda ressalva que a variação encontrada no conteúdo de DNA não poderia simplesmente ser explicada por variações no conteúdo de DNA das heterocromatinas. Embora o autor descreva e comente o DNA heterocromático de Crotalaria, não havia descrições sobre estas estruturas em espécies do gênero. Em um estudo sobre cromossomos paquitenicos Gupta \& Gupta (1978b) apresentam em seus desenhos de câmara clara estruturas semelhantes à heterocromatina, mas no texto não há 
qualquer comentário sobre elas. Por aqueles desenhos fica claro que a heterocromatina ficaria próxima ao centrômero e blocos intersticiais e terminais são raramente observados.

As observações de cromossomos paquitenicos e sua comparação com cromossomos mitóticos a partir de medidas dos cromossomos (Gupta \& Gupta 1978a e Gupta \& Gupta 1978b) mostrou que os cariótipos eram simétricos em ambos os casos, sendo a maioria das espécies constituídas de cromossomos metacêntricos e submetacêntricos. Os autores propõem que a uma tendência de cariótipos assimétricos para simétricos, entretanto esta tendência teria sido secundariamente derivada. Deste modo concluem que mudanças estruturais poderiam estar envolvidas na evolução dos cariótipos, mas não os alteraria de forma significativa. Esta observação dos autores, de certa forma, contradiz o que foi proposto no trabalho anterior de Gupta (1976) de que as variação quantitativas no conteúdo de DNA, teriam importante papel na evolução do gênero. Uma última observação destes trabalhos sugere que, a seção Incanae tenha se originado da seção Grandiflorae pelo aumento de tarnanho dos cromossomos menores em relação aos maiores, acompanhado pela redução do número de cromossomos (Gupta \& Gupta 1978a e Gupta \& Gupta 1978b).

Raina \& Verma (1979) descrevem o cariótipo de uma série de espécies de Crotalaria e fazem algumas considerações importantes a respeito da organização cromossômica no gênero. Primeiro descrevem que embora vários trabalhos tenham relatado a presença de várias constrições secundárias e satélites, no trabalho delas apenas o par maior de cromossomos possuía constrição secundária. A posição desta constrição secundária no cromossomo 1 variava para as diferentes espécies, sendo possível a identificação de três categorias: a pimeira com a constrição secundária bem próxima ao centrômero, outra um pouco mais distante do centrômero e a terceira com a constrição secundária bem próxima a metade do braço cromossômico. Os autores concluem que esta variação pode ter se derivado através de deleções , translocações desiguais, ou inversões, de modo que em algumas espécies somente um pequeno segmento de cromatina separa a constrição primánia da secundária, sendo presumível que durante a evolução houve perdas neste pedaço de cromatina de modo que as duas constrições passam a ocupar praticamente o mesmo loco. Os autores ainda descrevem os cariótipos de espécies de Crotalaria como tendo uma grande estabilidade 
morfológica, para tamanho e forma dos cromossomos, de modo que a especiação pode não estar correlacionada com a diferenciação cromossômica. Os autores propõem que em cariótipos extremamente similares, evidencias de diferenciação podem ser obtidas estimandose o conteúdo de DNA, tal como foi encontrado nas estimativas de Gupta (1976). Raina \& Verma (1979) ainda discustem a origem do número de cromossomos na subseção Incanae, utilizando-se da mesma discussão de Senn (1938). Sobre número de cromossomos, os autores ainda fazem uma discussão do porque o gênero não poderia ser $x=4$, mas $\operatorname{sim} x=8$, uma vez que esta proposta havia sido cogitada em trabalhos anteriores. Eles justificam que nunca foram observadas espécies de Crotalaria com $\mathrm{x}=4$ e que a observação da meiose de várias espécies não indicavam a formação de multivalentes nas espécies diplóides. $\mathrm{Na}$ verdade, embora houvesse uma proposta sobre $\mathrm{x}=4$ como número básico de cromossomos para o gênero Crotalaria, esta hipótese nunca foi levada a sério e raramente figurou nos trabalhos mais importantes. A estratégia dos autores foi a de chamar a atenção para um trabalho que publicaram a seguir sobre comportamento meiótico em uma série de espécies do gênero Crotalaria.

Um estudo sobre meiose publicado por Verma \& Raina (1980) traz grandes novidades sobre a espécies de Crotalaria até então estudadas. A maioria das espécies foram descritas como sendo estáveis com oito bivalentes, entretanto em algumas espécies uma série de anormalidades de significância foram encontradas. A formação de multivalentes é descrita para as espécies $C$. sericea, $C$. incana, $C$. usaromoensis, $C$. intermédia e $C$. lanceolata, o que poderia ser interpretado como o resultado de uma série alterações estruturais dos cromossomos. Pontes com e sem fragmentos atrasados foram encontrados nas espécies $C$. lanceolata e C. retusa, sendo que nesta última, vários tipos de pontes foram descritas indicando que estas espécies podem ser heterozigotas para inversões paracêntricas. As autoras ainda discutem que no caso das espécies poliplóides, apesar da alta estabilidade cromossômica, assumir que estas espécies sejam de natureza alopoliplóide ou mesmo alopoliplóide de segmento pode ser um erro, uma vez que as associações cromossômicas em autopoliplóides induzidos de $C$. sericea, $C$. brownei, $C$. retusa, $C$. juncea e $C$. verrucosa são freqüentemente bivalentes. A poliploidia foi muito significante se levarmos em consideração as espécies americanas do gênero, principalmente as pertencentes à seção Calycinae, como 
considerou Windler (1974).

Verma \& Raina (1981) dedicam um trabalho todo à descrição da meiose de $C$. agatiflora. Esta espécie foi a única a apresentar número variável de nucléolos. Todas as espécies descritas no trabalho anterior (Verma \& Raina, 1980) tinham apenas um nucléolo. Esta espécie está subdividida em cinco subespécies, e os múltiplos nucléolos foram considerados como resultado de intercruzamentos entre estas subespécies, uma vez que intermediários foram descritos para as subespécies (Polhill, 1982). Os autores postulam que $C$. agatiflora ativa organizadores nucleolares latentes de tamanhos diferentes de acordo com o número de repetições de rDNA que cada sítios contêm.

Verma et al. (1984) descreveram o cariótipo de uma outra série de espécies de Crotalaria. Os autores seguiram praticamente a mesma linha do trabalho anterior (Raina \& Verma, 1979). Algumas observações foram repetidas neste trabalho, tal como, a variabilidade das posições da constrição secundária, que poderia ser dividida em três e a de que o maior par de cromossomos era sempre o que continha a constrição secundária (Raina \& Verma, 1979). Verma et al. (1984) voltam a discutir sobre o número básico de cromossomos e a origem do número $\mathrm{x}=7$ para a subseção Incanae, entretanto, passam a admitir a proposta feita por Gupta \& Gupta (1978a) e Gupta e Gupta (1978b) de que a subseção Incanae surgiu a partir da seção Grandiflorae, como visto anteriormente. Observaram ainda que os cariótipos de espécies de Crotalaria não apresentam variações abruptas para o tamanho dos cromossomos dentro de um complemento, e que na verdade o tamanho dos cromossomos decrescem como um gradiente continuo do maior para o menor. Observaram também que a diferença entre o maior e o menor cromossomo, era de aproximadamente 1,5 vezes. Estas observações confirmam um postulado anterior de Raina \& Verma (1979) de que provavelmente a especiação não estava correlacionada com a morfologia e a simetria dos cariótipos e que evidências deste tipo poderiam ser encontradas com a estimativa do conteúdo de DNA das espécies de Crotalaria. Os autores ainda descrevem alguns heteromorfismos para o par de cromossomos com constrição secundária, e argumentam que a observação de apenas um cromossomo com constrição secundária é resultado de anfiplastia, no qual o organizador nucleolar de um genoma pode ser dominado pelo de outro, a partir de uma origem híbrida. Entretanto, como visto anteriormente e os próprios autores discutem, não há registro de híbridos interespecíficos 
no gênero Crotalaria e como a meiose é nornal, passam a justificar esta anfiplastia observada como uma diferenciação de natureza gênica ou devido a uma estrutura híbrida críptica, mas não apresentam citações que suportem estas hipóteses. Destacam ainda que as espécies poliplóides estudadas não eram resolvidas em agrupamentos de dois pares de cromossomos, mas sim em pares simples, suportando assim a proposta de que estas espécies tinharn uma origem alopoliplóide ou alopoliplóide segmentado (Verna et al., 1984). Os autores terminam o trabalho discutindo que as diferenças de tamanho dos cromossomos nas várias espécies estudadas não foram criticamente investigadas, mas pode ser observada uma tendência de redução do tamanho dos cromossomos com o aumento da poliploidia. Esta redução estaria associada à adaptação dos poliplóides e a manutenção de um balanço núcleo-citoplasma, próximo ao da diploidia (Verna et al., 1984). Entretanto, devido às técnicas citológicas utilizadas por estes e outros autores e devido às influencias ambientais, os dados de tamanho de cromossomos não foram comparáveis (Raina \& Verma 1979; Verma et al., 1984).

A partir das observações dos cariótipos de espécies de Crotalaria durante os anos de 1970 e 1980, onde foram abordados temas como a origem do número básico $x=7$, variação no conteúdo de DNA e relações entre cariótipos de diferentes espécies, abre-se a perspectiva de uma nova abordagem de estudos. Era necessário um estudo crítico em que fosse possível a comparação de cariótipos de diferentes espécies e verificar o padrão cariotípico dentro de seções e subseções botânicas que forneceriam evidencias entre a especiação e a forma dos cariótipos. As observações de que apenas o par maior de cromossomos continha a constrição secundária e que havia um gradiente de redução no tamanho dos cromossomos do maior para o menor e a não ocorrência de cariótipos bimodais eram as peças chaves para estas comparações.

Entretanto o primeiro trabalho publicado na década de 1990 faz uma revisão sobre qual seria o número de cromossomos básico para o gênero Crotalaria. Sem expor qual era a opinião dos autores, Koul \& Mangotra (1991) apresentam as três teorias básicas: a primeira que sugeria que o grupo fosse $\mathrm{x}=4$ e que o grupo evoluiu através de poliploidia, entretanto, esta hipótese não foi comprovada pelas análises meióticas, onde se observavam apenas bivalentes; a segunda sugeria que o número básico seria básico $\mathrm{x}=7$ e que o número $\mathrm{x}=8$ foi secundariamente derivado, neste caso o número teria aumentado pela duplicação de um dos 
cromossomos do complemento e novamente os dados meióticos não suportam a hipótese; a terceira seria a de que o gênero é $\mathrm{x}=8$ e que houve uma redução do número de cromossomos para $x=7$, através de aneuploidia ou translocações, como foi sugerido por Senn (1938). Este trabalho traz ainda uma colocação interessante sobre a segunda teoria. Koul \& Mangotra (1991) discutem que o número $\mathrm{x}=8$ poderia estar associado aos grupos mais avançados, e que entretanto, este número também ocorre em grupos primitivos e esta seria a uma das razões para se refutar a segunda hipótese, além dos dados meióticos. Curiosamente o número $\mathrm{x}=7$ somente ocorre em espécies primitivas e nunca foi registrado em espécies com flores especializadas especializadas, de tal modo que a questão sobre o número de cromossomos permaneceu em aberto.

Palomino \& Vázquez (1991) estudaram as espécies $C$. spectabilis, C. longirostrata, C. pumila e $C$. incana, em preparações cromossômicas mais nítidas e com padrão de condensação muito semelhante que permitiu uma comparação entre os cariótipos destas espécies. Os autores observaram variabilidade de cariótipos para $C$. incana e discutem que esta espécie é variável em diferentes populações ao redor do mundo e concluem que estas variações seriam consequiência de uma série de translocaçōes dentro do complemento de $C$. incana, apoiando a interpretação de Chennaveeraiah \& Patil (1973). Palomino \& Vázquez (1991) estudaram uma espécie poliplóide e relataram que espécies poliplóides com 2n=32 cromossomos foram observadas em pelo menos 20 espécies do novo mundo, com provável origem das mesmas por alopoliploidia a partir de um fluxo migratório vindo do leste da Ásia. $O$ evento de poliploidização teria grande importância nas espécies americanas, principalmente no México e América do Sul onde as características morfológicas diferem muito daquelas presentes em espécies da África e Ásia, entretanto nestes dois últimos continentes o mecanismo de especiação por poliploidia não teria importância uma vez que apenas uma espécie, C. massaiensis, foi descrita como poliplóide.

Um trabalho interessante foi realizado por Cequea \& Nirchio (1998). Estes autores estudando a meiose de $C$. stipularia testaram-na quantitativamente em modelos que utilizarn o pareamento meiótico como parâmetros a serem testados para confirmar se a espécie possui um comportamento de auto ou alopoliploidia. Pelas fórmulas utilizadas e pelas configurações obtidas na diacinese, concluiram que $C$. stipularia é estritamente alopoliplóide com 
pareamento perfeitamente diplóide o que the garante quase que $100 \%$ de viabilidade dos gametas.

Oliveira \& Aguiar-Perecin (1999) fizeram um estudo complementando questões que permaneceram em aberto nos trabalhos de Boulter et al. (1970), Gupta \& Gupta (1978a), Raina \& Verma (1979) e Verrna et al. (1984). Através de um pré-tratamento adequado com hidroxiquinolina, obtiveram preparações com um padrão homogêneo de condensação dos cromossomos, o que permitiu uma comparação e análise morfométrica dos cariótipos de diferentes espécies e também entre seções botânicas. Confirmaram observações anteriores, de que, os cromossomos têm centrômeros predominantemente medianos, com a constrição secundária sempre no maior par e há um decréscimos continuo do tamanho dos cromossomos do maior para o menor. Os dados permitiram uma avaliação das características dos cariótipos dos grupos de espécies de cada seção ou subseção estudada: Calycinae apresenta os cariótipos com maiores índices de simetria, índice calculado pela soma dos braços curtos dividido pela soma do comprimento dos cromossomos, o que a distingue das demais seções. Na seção Crotalaria foi possível separar as duas subseções Crotalaria e Longirostres, sendo que esta última, apresenta cariótipos mais assimétricos e com maior relação entre o maior e menor cromossomo, enquanto na subseção Crotalaria os cromossomos são maiores, mais simétricos e com menor relação entre o maior e o menor cromossomo do complemento. As autoras sugerem então que ocorre maior similaridade entre cariótipos de espécies relacionadas, dentro das respectivas entidades taxonômicas. A descrição do cariótipo de $C$. incana, mostra que esta espécie tem comprimento do lote haplóide similar à maioria das espécies diplóides, apesar de ter um cromossomo a menos no complemento, além disso, os dois primeiros pares de cromossomos são relativamente maiores que o terceiro. Foi levantada a hipótese de que esta espécie tenha surgido por aneuploidia a partir de espécies da própria seção Chrysocalycinae, uma vez que as maiores similaridades de cariótipos são encontradas dentro das próprias seções botânicas. Esta observação contradiz aquela proposta por Gupta \& Gupta (1978a) e Gupta \& Gupta (1978b), de que a espécie $C$. incana teria se originado da seção Grandiflora também por aneuploidia. Entretanto, parece mais lógico a ocorrência de eventos dentro de um mesmo grupo botânico, originando novas espécies, do que eventos que ocorram em outros grupos gerando espécie que apresentam características semelhantes a um terceiro grupo, assim a 
proposta de Oliveira \& Aguiar-Perecin (1999) é mais parcimoniosa do que as demais.

Dentro da seção Calycinae, Oliveira \& Aguiar-Perecin (1999) contatararn que apesar das espécies diferirem em ploidia, o grau de simetria e a relação entre o maior e o menor par de cromossomos são muito semelhantes entre as espécies, e que o comprimento do lote haplóide das espécies poliplóides não é o dobro em relação à espécie diplóide. Portanto, C. paulina e $C$. stipularia ambas com $2 \mathrm{n}=32$ cromossomos, possuem cromossomos menores do que a espécie $C$. juncea e demais diplóides do gênero, com exceção a $C$. virgulata subsp. grantiana. Esta observação comparativa entre os cariótipos de espécies poliplóides com diplóides, sugere que deve ter ocorrido redução no conteúdo de DNA durante a evolução. $\mathrm{O}$ número de constrições secundárias dos poliplóides, não coincide com o grau de ploidia, e foi levantada a hipótese de ocorrência de anfiplastia e uma provável origem alopoliplóide, a partir de espécies da própria seção Calycinae e que a ocorrência de poliploidia em espécies americanas da seção Calycinae, indica que este fenômeno tem um importante papel na diversificação do gênero no centro secundário de origem desta seção.

Oliveira \& Aguiar-Perecin (1999), além da observação de similaridades de cariótipos dentro de seção e subseção, constataram diferenças entre seções que poderiam ser devidas à ocorrência de rearranjos cromossômicos, como é o caso de $C$. spectabilis que difere da outras espécies, inclusive $C$. retusa da mesma seção, por ter sua constrição secundária no braço longo, enquanto as demais espécies apresentam no braço curto, indicando a ocorrência de uma inversão pericêntrica. Esta observação para $C$. spectabilis, difere daquelas feitas por Gupta \& Gupta (1978a), Raina \& Verma (1979) e Palomino \& Vázquez (1991), o que poderia sugerir uma divergência entre populações asiáticas, mexicanas e brasileiras, ou possivelmente problemas de interpretação em observação de metáfase com cromossomos muito condensados.

Outra observação importante feita por Oliveira \& Aguiar-Perecin (1999) é a de que C. virgulata subsp. grantiana embora esteja classificada na seção Crotalaria, seu cariótipo difere das espécies $C$. spectabilis e C. retusa, pertencentes à mesma seção, como visto acima, o que dá suporte a subdivisão destas espécies em duas subseções, segundo Polhill (1982). Bisby \& Polhill (1973) localizam esta espécie em uma posição periférica na seção Crotalaria, sendo muito próxima da seção Dispermae. Os cromossomos de C. virgulata subsp. grantiana 
são curtos como aqueles observados na seção Dispermae (Boulter et al., 1970), mostrando que as duas seções botânicas estão estritamente correlacionadas.

A seção Crotalaria apresenta flores especializadas, mas na seção Longirostres a especialização morfológica é progressivamente maior, próximo ao observado na seção Dispermae, a mais especializada do gênero (Bisby \& Polhill, 1973; Polhill, 1982). Assim os dados citológicos de Boulter et al. (1970) e Oliveira \& Aguiar-Perecin (1999), apontam que nas seções mais especializadas a evolução tende à redução dos cromossomos, bem como para um menor índice de simetria dos cariótipos. Desta forma, analises de cromossomos no gênero Crotalaria continuam indicando uma possível direção na evolução cariotípica no gênero como um todo.

\subsection{Estrutura dos cromossomos de espécies da família Leguminosae-Papilionoideae}

\subsubsection{Bandamento-C em espécies da família Leguminosae}

A técnica de bandamento-C permite a visualização de blocos de heterocromatina constitutiva em cromossomos metafásicos. Esta heterocromatina pode estar em diferentes posições nos cromossomos, pode alterar o tamanho dos braços e ser polimórfica para presença ou ausência, tal como foi observado em cromossomos mitóticos de milho (Aguiar-Perecin \& Vosa, 1985).

Embora existam alguns estudos sobre bandamento-C em leguminosas, principalmente no gênero Lathyrus (Narayan, 1982; Narayan \& Durrant, 1983; Narayan, 1983), somente na última década é que esta técnica foi empregada em um maior número de espécies dessa família (Galasso et al., 1992; Galasso et al. 1993; Raina \& Mukai, 1998; Bauchan et al., 1999; Falistocco \& Falcinelli, 1993; Moscone et al., 1999; Ünal et al., 1995; Cremonini et al., 1993).

A partir do trabalho de Galasso et al. (1992) onde os autores descrevem um protocolo de bandamento-C que permitiu a visualização do padrão de bandas de espécies do gênero Vigna, é que outros trabalhos se desenvolveram. A grande 
dificuldade para aplicação desta técnica é que a família, de modo geral, apresenta cromossomos pequenos.

A aplicação da técnica de bandamento-C tem demonstrado uma predominância de bandas na região centromérica dos cromossomos de diferentes gêneros, tais como Vigna, Medicago, Arachis, Lathyrus, Phaseolus e Vicia atropurpurea (Galasso et al., 1992; Galasso et al., 1993; Raina \& Mukai, 1998; Bauchan et al., 1999; Falistocco \& Falcinelli, 1993; Moscone et al., 1999; Ünal et al., 1995; Cremonini et al., 1993). Entretanto, no gênero Vicia este padrão não é observado em todas as espécies. Este gênero se caracteriza por apresentar bandas-C interesticiais e terminais (Fuchs et al., 1998b; Cremonini et al. 1998; Cremonini et al., 1998). Schubert \& Rieger (1990) demonstraram que este padrão de bandas é o resultado de rearranjos que ocorreram nos cromossomos das espécies desse gênero. Fuchs et al. (1998b) apresentam em seu trabalho um esquema dos pontos de quebras, onde os cromossomos sofreram rearranjos em relação a um cariótipo ancestral. Somente a espécie Vicia atropurpurea apresenta um padrão de bandas-C centroméricas, e esta poderia ser considerada uma espécie mais antiga dentro do gênero (Cremonini et al. 1993).

A determinação do padrão de bandas heterocromáticas reveladas pelo bandamento-C em espécies do gênero Vicia, serviu para mapeamento de marcadores para o estudo da evolução dos cariótipos da espécie cultivada, Vicia faba (Fuchs et al., 1998b). No gênero Vigna foi possível a distinção de quatro espécies do gênero através do padrão de bandas-C, demontrando que $V$. vexillata não está correlacionada com as demais espécies estudadas (Galasso et al., 1993).

Polimorfismos no padrão de bandas- $C$ também foi observado dentro da família. Estudos no gênero Medicago revelaram que a espécie M. sativa ssp. falcata, apresenta uma variação do padrão de bandas conforme a sua localização (Bauchan et al., 1999). Apesar do padrão de bandas centroméricas ser altamente conservado, as poucas bandas terminais serviram como marcadores para o estudo de polimorfismos e de alterações cromossômicas, como a presença de úm isocromossomo em estado heterozigótico em acessos da Suíça (Bauchan et al., 1999). 
O conteúdo de DNA varia muito dentro da família Leguminosae, de $0,9 \mathrm{pg}$ em algumas espécies de Phaseolus a 27 pg em espécies do gênero Vicia (veja Bennett \& Leitch, 1995; Bennett \& Leitch, 1997). Estudos utilizando bandamento-C tentaram explicar esta variação do conteúdo de DNA, principalmente entre espécies do gênero Lathyrus (Narayan, 1982; Narayan, 1983; Narayan \& Durrant, 1983; Narayan \& McIntyre, 1989; Narayan, 1998). O autor demonstrou por esta série de trabalhos que entre quatro espécies, a quantidade de DNA dobra, mas que existe um controle rígido nesta variação. Narayan (1983) concluiu que os menores cromossomos do complemento de uma espécie teriam ganhos superiores na quantidade de DNA do que os maiores, o que resultaria em uma variação continua no tamanho dos cromossomos dentro de espécies mais evoluídas. Entretanto, entre as espécies existe uma descontinuidade de variação, principalmente entre o DNA total e o DNA altamente repetitivo encontrado nas bandas-C. Pelo padrão de bandamento-C é possível observar que o tamanho das bandas aumenta de uma espécie para outra, mas o autor deixa claro que não somente o DNA dos blocos heterocromáticos é o responsável pelo aumento no conteúdo de DNA, também outros tipos de seqüências no DNA eucromático têm grande peso sobre esta variação.

Dentro deste contexto torna-se importante o estudo do padrão de bandamento-C de espécies do gênero Crotalaria para: 1.) melhor entendimento da evolução do gênero que tem grande importância na agricultura sustentável; 2.) interpretação dos processos evolutivos envolvidos na origem das espécies poliplóides e da variação do conteúdo de DNA, inferido indiretamente por mensuramento dos cromossomos que foram corados por técnicas convencionais de coloração (Oliveira, 1992; Oliveira \& Aguiar-Perecin, 1999).

\subsubsection{Coloração com fluorocromos e natureza dos blocos heterocromáticos}

A composição do DNA tem sido considerada como determinante primário para a diferenciação de bandas fluorescentes pela coloração com fluorocromos. Regiões dos cromossomos ricas em nucleotídios AT possuem especificidade para corantes fluorescentes como 2'4'-diamidino-2-fenilindol (DAPI) e quinacrina (Q), enquanto 
regiões ricas em GC possuem grande especificidade para corantes como a cromomicina $\mathrm{A}_{3}$ (CMA) (Schweizer, 1983). Estas regiões cromossômicas em plantas normalmente têm grande correspondência com seqüências de DNA altamente repetitivos localizadas nos blocos heterocromáticos e correspondentes às bandas C (Vosa, 1975; Kenton, 1991). Deste modo, a aplicação dos fluorocromos e sua especificidade tem permitido um melhor entendimento da estrutura dos cromossomos, bem como sobre a origem e evolução dos cariótipos de plantas, pois permitem uma comparação entre estes padrões de fluorescência, com o padrão de bandas- $C$, indicando a natureza das seqüências que constituem estes blocos heterocromáticos.

No gênero Sesbania (Leguminosae), por exemplo, foi observado que, a coloração com CMA permitiu a diferenciação de bandas fluorescentes correspondentes somente às regiões organizadoras do nucléolo (RON), e que estas variavam em número de dois a quatro dependendo da espécie. Neste estudo não foi possível a observação de fluorescência nas bandas- $\mathrm{C}$, exceto naquelas que estão adjacentes à região organizadora do nucléolo (Forni-Martins \& Guerra, 1999).

O mesmo padrão de diferenciação foi observado em Vicia atropurpurea onde a maioria das bandas $\mathrm{C}$ não apresentaram especificidade para ambos os fluorocromos DAPI e CMA, sendo que apenas o cromossomo contendo a RON apresentou bandas fluorescentes com CMA, adjacentes à constrição secundária, e bandas DAPI na região proximal e terminal do braço longo (Cremonini et al., 1993).

Em ambos os casos descritos anteriormente, os autores não discutem a natureza das seqüências de DNA presentes nas bandas $\mathrm{C}$, ou seja, se ricas em nucleotídios AT ou GC. Somente foi possível fazer esta inferência nos casos em que a banda é fluorescente para um dos corantes. É comum a ocorrência de bandas-C que não apresentam reação para nenhum tipo de fluorocromo, seja ele específico para regiões ricas em AT ou GC, bem como ocorre casos em que as bandas-C são fluorescentes para ambos os tipos de corantes, nestes casos as bandas-C têm sido classificadas como neutras, tal como feito por Guerra (2000), ou seja não podem ser classificadas quanto a natureza das seqüências que as compõem, se ricas em AT ou GC. 
Em Vicia faba, estudos utilizando coloração com fluorocromos revelou diferenciação de bandas: com exceção das bandas adjacentes à RON, as bandas-C são ricas em AT por apresentarem fluorescência para coloração com DAPI/AMD (actinomicina D). O AMD que é um antibiótico funciona como um contracorante que se liga aos resíduos de GC, permitindo um maior contraste da fluorescência de regiões ricas em AT (Schweizer, 1976a; Schweizer, 1976b). Esta observação foi comprovada pela observação do mesmo padrão de bandas fluorescentes, obtidas por outros fluorocromos específicos para regiões ricas em AT, tal como o Hoechst 33258. Somente a RON apresentou fluorescência com o fluorocromo CMA combinado com distamicina (DA), indiando uma alta concentração de GC nesta região (Fuchs et al., 1998b).

Em Vigna, um dos gêneros mais importantes da família Leguminosae, não foi observada a ocorrência de bandas fluorescentes para o fluorocromo DAPI, somente bandas fluorescentes CMA puderam ser observadas (Galasso et al., 1993). Como se trata de um gênero com cromossomos muito pequenos, a correspondência entre diferentes tipos bandamento e a RON, somente foi obtida após a hibridação molecular in situ de sondas de DNA ribossômico (rRNA 18S-5,8S-26S). Todas as bandas fluorescente para CMA correspondiam a estas regiões de rDNA, e ainda para a espécie $V$. unguiculata houve grande variabilidade no número de bandas fluorescentes com CMA nas diferentes cultivares e acessos da coleção de germoplasma com coletas em diferentes locais (Galasso et al., 1998).

Em todos os trabalhos a utilização destes fluorocromos permitiu uma visualização dos processos evolutivos e de domesticação das espécies estudadas. Assim, esta ferramenta tem grande potencial para a caracterização dos cromossomos e fornecerá marcadores para o entendimento dos processos evolutivos dentro do gênero Crotalaria.

\subsubsection{Hibridação molecular in situ e o mapeamento físico de seqüência repetitivas}

A hibridação molecular in situ fluorescente ou não, é uma técnica que permite a localização física nos cromossomos de determinadas seqüências de DNA utilizadas como sondas e que por conterem alguns dos seus nucleotídeos marcados, estas seqüências de DNA podem ser detectadas por diversas técnicas, tais como preciptação 
de prata se a sonda é marcada com nucleotídeo radioativo, coloração através de uma digestão enzimática de um substrato que resulta em cor e a mais utilizada atualmente a deteç̧ão da sonda marcada com anticorpo ligado a um corante fluorescente. A técnica de hibridação molecular in situ é conhecida desde o final dos anos 1960, mas passou a ser utilizada mais intensamente no final dos anos de 1980.

Os trabalhos de hibridação molecular in situ em cromossomos de espécies de leguminosas são mais antigos do que os abordados nesta revisão, entretanto, consideramos relevante apenas abordar os trabalhos a partir da década de 1990, quando à aplicação de sondas frias, marcadas com fluorescência, passaram a ser utilizadas mais rotineiramente nos trabalhos. São desta fase os trabalhos que permitiram um melhor entendimento sobre a estrutura, a oranização e a evolução dos cromossomos de espécies da família Leguminosae.

Murray et al. (1992) aplicando hibridação molecular in situ da sonda de rDNA de $45 \mathrm{~S}$ e utilizando deteç̧ão do sinal de hibridação através de digestão enzimática de fosfatase alcalina, bem como coloração com nitrato de prata que detecta regiões organizadoras do nucléolo que foram ativas na interfase anterior em espécies de Lathyrus, não encontraram correspondência entre o número de sinais de hibridação e o número de marcações com coloração com nitrato de prata. Por exemplo, a espécie Lathyrus sativus apresentava quatro sinais de hibridação da sonda ribossomal, enquanto apenas três cromossomos apresentavam marcação com nitrato de prata, indicando que um dos sítios detectado pela sonda estava inativo.

GALASSO et al. (1995) fazem uma caracterização muito detalhada dos cromossomos de Vigna unguiculata, utilizando-se de sondas de rDNAs de 45S e 5S, seqüências teloméricas e uma seqüências repetitiva isolada da região centromérica. Vigna unguiculata mostrou múltiplos sítios de rDNA de $45 \mathrm{~S}$ localizados em diferentes cromossomos e dois pares de cromossomos com rDNA de 5S, sendo que um destes aparecia próximo a um dos sítios de rDNA de $45 \mathrm{~S}$ e outro em um cromossomo sem estes marcadores. Destes sítios de rDNA de 45S apenas os quatro maiores apresentavam marcação pelo nitrato de prata, enquanto que os sítios ménores não. Esta observação foi interpretada como uma inativação deste loco, mas que não necessariamente ele seja 
inativo durante todo o ciclo de vida da planta. As marcações com a sonda telomérica, como esperado, marcaram as regiões terminais dos cromossomos, tendo sido encontradas variações de intensidade dos sinais nos diferentes pares. Uma seqüência repetitiva isolada aparece hibridizada nas regiões centroméricas, e é espécie-específica para Vigna unguiculata como demonstraram experimentos de hibridação em membranas (Southern). Considerou-se que apesar desta observação, esta seqüência não parece estar relacionada com a estrutura do centrômero, mas apenas se localiza em uma região pericentromérica.

A expressão dos genes ribossomais também é o assunto principal da investigação feita por Shi et al. (1996). Neste trabalho os autores utilzaram como modelo a soja (Glycine max) e o feijão comum (Phaseolus vulgaris) e observaram que nem todos os sinais de rDNAs de $45 \mathrm{~S}$ e $5 \mathrm{~S}$ em núcleo interfásico, encontravam-se associados ao nucléolo. Apenas um par de blocos heterocromáticos localizados nos sítios de rDNA de $45 \mathrm{~S}$ e um de $5 \mathrm{~S}$ apareciam ligadas a esta região, enquanto que as demais heterocromatinas com sinais destas sondas apareciam em regiões mais distantes dentro do núcleo em relação ao nucléolo. Shi et al. (1996) concluíram que esta observação era coerente com aquela dos sítios que realmente são ativos nestas duas espécies, além de terem traçado um esquema da organização do núcleo interfásico nestas espécies.

Entretanto, não somente rDNAs são assuntos de interesse daqueles que estudam a organização e a evolução dos cromossomos de espécies de Leguminosa. Como apresentado anteiormente nesta revisão, uma das grandes incógnitas sobre a evolução destas espécies, está na grande variação do conteúdo de DNA. Pearce et al. (1996) procurou entender a variação no conteúdo de DNA de espécies de Vicia baseando-se no estudo de retrotransposons do grupo Ty1-copia. Os estudo mostrou através da hibridação molecular in situ desta sonda que este tipo de elemento encontra-se disperso pelo genoma, mas não ocupa regiões de heterocromatina constitutiva e concluem que nem a heterogeneidade e nem o número de cópia destas seqüências tinham relação com a variação do conteúdo de DNA em espécies de Vicia.

Nesta mesma linha de raciocínio GALASSO et al. (1997) estudaram o grupo Ty1-copia em espécies de Vigna. Estes autores descobriram que este grupo de 
retroelementos são os maiores constituintes do genoma de espécies do gênero Vigna. Como observado anteriormente para Vicia, estes retroelementos não são visualizados nas regiões de heterocromatina pericentromérica, nas regiões organizadoras do nucléolo e nem em regiões subteloméricas, sendo que nas demais regiões da cromatina apresentam uma distribuição uniforme, sendo que poucos sítios apresentam uma concentração maior destes elementos.

Fuchs et al. (1998b) realizaram em Vicia faba o mapeamento fisico de diferentes seqüências de DNA repetitivo ou de genes. Esta espécie foi primeiramente mapeada por técnicas clássicas de bandamento-C e coloração com fluorocromos, além disso foram estudadas regiões de replicação do DNA através da incorporação de BrdUrd para determinar regiões de replicação precoce e tardia, digestão do DNA cromossômico in situ obtendo-se padrões coincidentes com algumas bandas- $\mathrm{C}$ do genótipo estudado. Após esta caracterização diversos tipos de seqüências foram mapeados nos cromossomos de Vicia faba e este detalhamento dos cromossomos desta espécie permitiu a visualização de aspectos da organização do seu genoma. Foram mapeados duas seqüências repetitivas que tinham correspondência com regiões de replicação tardia e bandas-C, sendo elas o elemento FokI com 59 pb e o arranjo pVf7 com 321 pb. A seqüência telomérica hibridizou-se de acordo com o esperado, nas posições terminais dos cromossomos, sendo encontrados sítios intersticiais no cromossomo 2 resultado de uma inversão paracentrica. A região subtelomérica isolada a partir de primers degenerados, amplificou um arranjo de 172 pb que hibridizou-se em regiões adjacentes aos telômeros. Os microsatélites GATA, GGAT, CAC e AG, não apresentaram distribuição homogênea nos cromossomos de Vicia faba, mas sim, em regiões específicas ricas nestas seqüências, representando ótimos marcadores cromossômicos. Além destes, ainda foram mapeados os genes de rDNA de $45 \mathrm{~S}$ e $5 \mathrm{~S}$ e famílias de genes como leguminina $\mathrm{A}$, leguminina $\mathrm{B} 3$, leguminina $\mathrm{B} 4$, uma proteína de reserva nãoidentificada (unknow seed protein - USP) e da vicilina (Fuchs et al., 1998b). Além deste trabalho, uma seqüência isolada de Vicia faba, apresentou distribuição homogênea ao longo de todos os cromossomos, com exceção das regiões heterocromáticas, um padrão muito semelhante a aquele anteriormente descrito para o grupo de retrotransposons $T y 1$ - 
copia, entretanto parece não haver homologia entre estas seqüências (Frediani et al., 1999). Certamente, Vicia faba tem os cromossomos mais bem detalhados e mapeados das espécies da família Leguminosae. Detalhamento deste tipo também foi feito em Cicer arietinum (Grão-de-bico), utilizando-se microsatélites e seqüências teloméricas (Gortner et al., 1998). Entretanto, neste caso os microsatélites apresentaram marcações ao longo dos cromossomos e poucas regiões de maior concentração (Gortner et al., 1998). Curiosamente, o DNA telomérico não apresentou marcações nas posições terminais, mas somente uma grande região do braço curto do cromossomo A e do B.

Entretanto, outros estudos, talvez menos complexos pelos seus próprios objetivos foram feitos em diversas espécies da família Leguminosae. Por exemplo, Galasso et al. (1998) estudou diversos acessos de Vigna unguiculata ssp. unguiculata e $V$. unguiculata ssp. dekindtiana, quanto ao núemro de sítios de rDNA de $45 \mathrm{~S}$, sítios fluorescentes com CMA e sítios corados através de coloração com nitrato de prata. Foram detectados vários polimorfismos em diferentes acessos de vários países, sendo que a FISH de rDNA detectou sempre um lóco a mais de rDNA em relação à coloração com CMA, este sítio adicional foi sempre menor que os demais e a coloração com nitrato de prata indica que ele é inativo (Galasso et al., 1998).

Em um estudo sobre localização de DNAs ribossomais no gênero Arachis (amendoins) não foi detectado quase que nenhum polimorfismo quanto ao número de sítios de rDNA de $5 \mathrm{~S}$, sendo que a grande variabilidade de número foi encontrada para o rDNA de 45S (Raina \& Mukai, 1999). A maioria das espécies possuíam sítios adicionais de rDNA de 45S, sendo estes descritos em cromossomos que não apresentavam constrições secundários e por isso descritos como inativos (Raina \& Mukai, 1999). Outra grande variabilidade foi encontrada quanto à posição destes locos nos cromossomos. Em um grupo de espécies os dois tipos de rDNAs apareciam colocalizados, enquanto em outro grupo o rDNA de $5 \mathrm{~S}$ aparece em um cromossomo sem sítios de rDNA de 45S (Raina \& Mukai, 1999). Embora os autores tenham encontrado todo este polimorfismo, este não foi bem explorado, para inferir quanto à origem das espécies poliplóides e a concordância dos agrupamentos de espécies em seções. 
Neste mesmo sentido Ansari et al. (1999) estudaram a organização dos rDNAs de 45S e 5S no gênero Trifolium, na tentativa de se encontrar um ancestral para a espécie poliplóide $T$. repens (trevo-branco). O mapeamento destes DNAs mostrou 7 classes de localização destes DNAs (Ansari et al., 1999). Estas classes permitiram inferir, por exemplo, que $T$. uniflorum $(2 \mathrm{n}=32)$ tenha se originado de $T$. nigrescens ssp. nigrescens, pois a espécie poliplóide possui o dobro de cromossomos marcadores que a espécie diplóide e com a mesma morfologia (Ansari et al., 1999). Entretanto, a indicação de um ancestral para $T$. repens é mais difícil, pois o número de sítios de rDNAs é correspondente aos das espécies poliplóides relacionadas, porém diferem em morfologia. Os autores sugerem que provavelmente a espécie ancestral seja do mesmo grupo botânico a que pertence $T$. repens, e que esta espécie sofreu perda total dos locos de rDNAs de um dos pares retornando a um estado diplóide (Ansari et al., 1999).

Outro trabalho utilizando-se de rDNAs foi realizado por ALI et al. (2000). Espécies do gênero Lathyrus mostraram concordância entre a classificação botânica em seções e os dados citogenéticos obtidos com estes marcadores. Espécies com dois sítios de rDNA de $5 \mathrm{~S}$ no cromossomo 2, pertenciam à seção Clymenum, as espécies da seção Aphaca estão em posição intermediária entre as seções Clymenum e Lathyrus, diferindo destas pela posição das heterocromatinas e pelo tamanho dos cromossomos (Ali et al., 2000).

Em um estudo no gênero Vicia, Raina et al. (2001) mapeou os rDNAs de $45 \mathrm{~S}$ e $5 \mathrm{~S}$ e encontrou padrões de localização destas seqüências coerentes com a classificação botânica em complexos de espécies. As espécies pertencentes aos complexos Narbonensis e Villosa possuíam os rDNA de 5S localizado em cromossomos diferentes daqueles que continham o de $45 \mathrm{~S}$, enquanto no complexo Sativa, estes rDNAs estão localizados no mesmo cromossomo (Raina et al., 2001). Além disso, a variabilidade no número, tamanho e localização dos dois DNAs ribossomais puderam geralmente distinguir espécies dentro dos complexos Narbonensis e Sativa, entretanto no complexo Villosa esta distinção entre espécies não foi possível (Raina et al., 2001). Em outro trabalho com espécies do gênero Vicia, Navrátilová et al. '(2003), encontrou que espécies dentro da mesma seção botânica apresentam grandes diferenças na morfologia dos 
cromossomos, bem como no número e nos sinais de hibridação das seqüências de rDNAs, telômero e outras duas classes de DNAs repetitivos do gênero Vicia. Os autores concluem que isto pode ser conseqüência de uma grande distancia evolutiva entre os cariótipos das espécies estudadas. Assim, as seqüências repetitivas VicTR-A e -B foram somente informativas quanto à distinção de cada par de homólogos, mas como não apresentou um padrão idêntico de hibridação nas diferentes espécies, não foi possível a identificação de cromossomos hoemologos, como esperado (Navrátilová et al., 2003).

Além de fornecerem dados sobre a evolução dos cromossomos das diferentes espécies e também servirem como marcadores específicos para a identificação de cromossomos individuais nas diferentes espécies, os DNAs repetitivos mapeados via FISH ainda têm uma aplicação prática para os programas de melhoramento. $O$ primeiro passo para este uso prático é a integração dos grupos de ligação atualmente obtidos por meio de marcadores moleculares de diferentes naturezas aos cromossomos. Esta integração é feita utilizando-se os marcadores de DNA repetitivos que identificam cromossomos individuais das espécies e a hibridação de um "pool" de marcadores moleculares geneticamente ligados para uma maior amplificação do sinal. Assim, os grupos de ligação de Pisum sativum (ervilha) (Fuchs et al., 1998a), Lens culinares ssp. culinares (lentilha) (Galasso et al., 2001), Lotus japonicus (Pedrosa et al., 2002) e Phaseolus vulgaris (feijão comum) (Pedrosa et al., 2003), já foram integrados aos cromossomos e representam uma ferramenta indispensável para os programas que visam introgressão de genes de espécies relacionadas, bem como para o mapeamento de outros marcadores moleculares e a localização de QTL e RTL.

Portanto, através da utilização da técnica de FISH visou-se o mapeamento dos rDNAs ribossômicos de 45S e $5 \mathrm{~S}$ em espécies do gênero Crotalaria, primeiramente para a obtenção de marcadores que permitam a identificação de cromossomos individuais e ter um maior detalhamento dos cromossomos destas espécies, e em segundo espera-se que estes sirvam como marcadores para um melhor entendimento da relações entre as espécies e sua evolução. 


\section{MATERIAL E MÉTODOS}

\subsection{Materiais}

As espécies utilizadas no presente estudo estão descritas no quadro 1. Estas espécies fazem parte da coleção mantida no Departamento de Genética da ESALQ/USP. As espécies cultivadas foram cedidas anteriormente pela Pirahy Sementes (PiracicabaSP) e pelo Instituto de Zootecnia de Nova Odessa (SP) e multiplicadas no Departamento de Genética. Alguns materiais são derivados de plantas utilizadas em trabalho anterior (Oliveira \& Aguiar-Perecin, 1999) e os vouchers de identificação das espécies estão depositados no Herbário Alexandre Leal Costa, Instituto de Biologia, Universidade Federal da Bahia.

Quadro 1: Espécies de Crotalaria e respectivas seções e subseções botânicas

\begin{tabular}{|c|c|c|c|c|}
\hline Espécies & $2 n$ & Procedência & Registro & Código ESALQ \\
\hline \multicolumn{5}{|l|}{ Seção Calycinae } \\
\hline C. juncea & 16 & São Paulo & ALCB-22976* & CJ-1 \\
\hline C. paulina & 32 & Bahia & ALCB-22970 & $\mathrm{CP}-1$ \\
\hline C. stipularia & 32 & Bahia & ALCB-22959 & CST-1 \\
\hline \multicolumn{5}{|l|}{ Seção Crotalaria } \\
\hline \multicolumn{5}{|c|}{ Subseção Crotalaria } \\
\hline \multirow[t]{2}{*}{ C. spectabilis } & 16 & São Paulo & ALCB-22972 & CSP-1 \\
\hline & & & ALCB-22925 & \\
\hline \multicolumn{5}{|c|}{ Seção Chrysocalycinae } \\
\hline \multicolumn{5}{|l|}{ Subseção Incanae } \\
\hline C. incana & 14 & Minas Gerais & IZ- $873^{* *}$ & $\mathrm{Cl}-1$ \\
\hline
\end{tabular}

* ALCB - Herbário Alexandre Leal Costa - Bahia.

** IZ - Instituto de Zootecnia de Nova Odessa - São Paulo. 
As espécies $C$. juncea, $C$. paulina, $C$. stipularia e $C$. spectabilis são cultivadas, C. incana não apresenta importância agrícola. Todas são amplamente encontradas em beiras de estradas e áreas de pastagens sem manutenção. Destas quatro espécies somente C. paulina tem origem no Brasil (Lewis, 1987), a espécie C. stipularia segundo o próprio autor é descrita com dois centros de origem, um no Brasil e outro na Índia. As espécies $C$. juncea e $C$. spectabilis são originárias da Índia e $C$. incana tem como centro de origem o sul da África (Polhill, 1982), portanto estas espécies são introduções (Lewis, 1987).

\subsection{Germinação}

As sementes para germinarem foram escarificadas quimicamente com ácido sulfúrico puro, seguindo as etapas abaixo:

As sementes foram colocadas em ácido sulfúrico puro durante 20 minutos, em capela. Após o tempo de escarificação o ácido foi lavado cuidadosamente em água corrente, até que toda substância fosse eliminada. As sementes lavadas foram postas para secar em papel de filtro por 12 horas. Realizou-se a embebição das sementes em placa de Petri contendo papel de filtro umedecido, até as sementes incharem. Após embebição as sementes foram semeadas em Sphagnum umedecido sob temperatura controlada de 28 a $30^{\circ} \mathrm{C}$.

Em aproximadamente 18 horas, as raízes atingiram o tamanho entre 1 e $3 \mathrm{~cm}$, adequado para coleta e realização do pré-tratamento.

\subsection{Pré-tratamento de raizes com inibidores do fuso mitótico}

As raízes coletadas foram pré-tratadas com uma solução hidroxiquinolina a 300 $\mathrm{ppm}+$ cicloheximida a $6,25 \mathrm{ppm}$ por 1 hora e 30 minutos. Este pré-tratamento permite a obtenção de cromossomos em prometáfase e metáfase com nitidez de sua morfologia, $\mathrm{e}$ adequados para realização de bandamento-C, coloração com fluorocromos e mapeamento físico de seqüências repetitivas através de hibridação molecular in situ (FISH). 
Os materiais pré-tratados foram então fixados por 24 horas em solução de Carnoy ( 3 partes de álcool etílico e 1 parte de ácido acético). As raízes destinadas à coloração convencional pelo método de Feulgen, foram transferidas para uma solução de álcool a 70\%, após a fixação; as destinadas ao bandamento e hibridação molecular in situ (FISH) foram mantidas no fixador. Ambos os materiais foram conservados em congelador a $-4{ }^{0} \mathrm{C}$.

\subsection{Preparação de lâminas}

As pontas de raízes fixadas foram retiradas do congelador e quando atingiram a temperatura ambiente, foram lavadas rapidamente em tampão citrato (citrato trissódico mais ácido cítrico, 0,01M, pH 4,6) e a seguir colocadas em tubos do tipo eppendorf contendo solução enzimática de celulase a $2 \%$ mais pectinase a $6 \%$, pré-aquecidas a 37 ${ }^{0} \mathrm{C}$ e mantidas a esta temperatura. Após a reação, as pontas de raiz foram colocadas em placa de Petri com tampão citrato frio, mantida sobre um bloco de gelo. Cada raiz utilizada para uma preparação foi transferida para uma solução de ácido acético a $60 \%$ até que ficassem transparentes, o que poderia variar de 3 a 5 minutos. A raiz foi então resgatada com pipeta Pasteur e colocada gentilmente sobre a lâmina, e sua ponta foi esmagada cuidadosamente com uma pinça fina. O material foi coberto com lamínula, esmagado entre papel filtro para retirar o excesso de ácido acético e permitir o espalhamento dos cromossomos, e então observado em microscópio de contraste de fase.

As melhores lâminas tiveram as lamínulas removidas em nitrogênio líqüido quando destinadas ao bandamento com fluorocromos e FISH, e com solução de ácido acético a $45 \%$ quando destinadas ao bandamento- $\mathrm{C}$ ou quando coradas pelo método de Feulgen; e secas ao ar.

O material destinado à coloração com fluorocromos e FISH foi conservado em cubas altas com sílica gel para evitar hidratação. As cubas foram seladas e mantidas a $20{ }^{\circ} \mathrm{C}$. As lâminas para bandamento-C foram conservadas em cubas com álcool etílico absoluto em freezer a $-4{ }^{0} \mathrm{C}$. 


\subsection{Coloração pelo método de Feulgen}

$\mathrm{O}$ material conservado em álcool a $70 \%$ em freezer a $-4{ }^{0} \mathrm{C}$ foi deixado atingir temperatura ambiente. A seguir foi lavado por duas vezes em água destilada por 5 minutos, e então hidrolisado em uma solução pré-aquecida de ácido clorídrico $1 \mathrm{~N}$ por 8 minutos a $60{ }^{\circ} \mathrm{C}$. As raízes hidrolisadas foram novamente lavadas por duas vezes em água destilada por 5 minutos. A reação com reativo de Schiff foi realizada em câmara escura por 45 minutos e a seguir as raízes foram lavadas em água corrente em placas de Petri.

As melhores lâminas foram montadas permanentes com bálsamo do Canadá.

\subsection{Bandamento- $C$}

O bandamento-C seguiu a metodologia descrita por Aguiar-Perecin (1985) com modificações que revelaram bandas- $\mathrm{C}$ nos cromossomos das espécies estudadas.

O protocolo segue:

Lâminas mantidas em álcool etílico absoluto foram retiradas da geladeira $\mathrm{e}$ após atingirem a temperatura ambiente, foram secas ao ar.

Realizou-se então o tratamento das lâminas em solução saturada de hidróxido de bário (3g de $\mathrm{Ba}(\mathrm{OH})_{2}$ em $100 \mathrm{ml}$ de água desmineralizada, descarta-se $50 \mathrm{ml}$ e completa-se o volume para $100 \mathrm{ml}$ novamente) a $37^{\circ} \mathrm{C}$ por $10-20$ minutos. $\mathrm{O}$ material foi então lavado em água desmineralizada, até que todo o bário fosse retirado. A seguir o material foi rapidamente lavado em $2 x S S C$ à temperatura ambiente e incubado em nova solução pré-aquecida de $2 \mathrm{xSSC}$ a $60^{\circ} \mathrm{C}$ por uma hora. $\mathrm{O}$ material foi novamente lavado retirando todo o excesso da solução. Procedeu-se à desidratação em série alcóolica (70\%, 90\% e 100\%). As lâminas foram então secas ao ar. As lâminas secas foram coradas com corante de Giemsa a $2 \%$, diluído em tampão Gurr-BDH $(\mathrm{pH} 7,0)$. As lâminas foram montadas em balsamo do Canadá. 


\subsection{Coloração com fluorocromos}

A coloração com fluorocromos seguiu a metodologia descrita por Friebe et al. (1996) com algumas modificações.

\subsubsection{Coloração com DAPI (4'-6'-diamidino-2-fenilindol)}

As lâminas mantidas em freezer a $-20{ }^{\circ} \mathrm{C}$ com sílica gel, foram retidas e deixadas em suporte até atingirem temperatura ambiente.

Sobre a lâmina foram aplicados $25 \mu \mathrm{l}$ de uma solução de DAPI diluída em de tampão Mcllvaine (pH 7,0) na concentração de $0,2 \mu \mathrm{g} / \mathrm{ml}$, que foi coberta com lamínula de parafilme e mantida no escuro para coloração durante 30 minutos.

A seguir, a lamínula foi retirada e a lâmina lavada rapidamente em água deionizada, e então seca ao ar. Depois de seca, a lâmina foi montada com $5 \mu$ l de vectashield H-1000. Antes de serem observadas as lâminas foram deixadas no escuro em temperatura ambiente para estabilização dos corantes.

\subsubsection{Coloração com DAPI/AMD (4'-6'-diamidino-2-fenilindol/Actinomicina D)}

Após secagem das lâminas mantidas em freezer foram aplicados $25 \mu \mathrm{l}$ de uma solução de DAPI diluída em tampão Mcllvaine ( $\mathrm{pH} 7,0)$ na concentração de $0,2 \mu \mathrm{g} / \mathrm{ml}$, que foi coberta com lamínula de parafilme e mantida no escuro para coloração durante 30 minutos. A seguir a lamínula foi retirada e a lâmina lavada rapidamente em água deionizada, e então seca ao ar. Na lâmina seca foram aplicados $25 \mu \mathrm{l}$ de uma solução de actinomicina $\mathrm{D}$ (AMD) diluída em tampão fosfato $(\mathrm{pH} \mathrm{7,0)}$ contendo $1 \mathrm{mM}$ de EDTA, na concentração de $0,2 \mathrm{mg} / \mathrm{ml}$, que foi coberta com lamínula de parafilme e mantida no escuro durante 20 minutos. Novamente, retirou-se a lamínula e a lâmina foi lavada em água deionizada e posta para secar ao ar. Depois de seca a lâmina foi montada com $5 \mu$ l de vectashield H-1000. Antes de serem observadas, as lâminas foram deixadas no escuro em temperatura ambiente para estabilização dos corantes. 


\subsubsection{Coloração com CMA (Cromomicina $\mathbf{A}_{3}$ )}

Após secagem das lâminas foram aplicados $25 \mu \mathrm{l}$ de uma solução de CMA diluída em tampão McIlvaine ( $\mathrm{pH}$ 7,0) contendo $\mathrm{MgCl}_{2} 5 \mathrm{mM}$, na concentração de $0,5 \mathrm{mg} / \mathrm{ml}$, que foi coberta com lamínula de parafilme e mantida no escuro durante 2 horas. A seguir a lamínula foi removida e a lâmina lavada rapidamente em água deionizada, e posta para secar ao ar no escuro. Depois de seca a lâmina foi montada com $5 \mu \mathrm{l}$ de vectashield $\mathrm{H}-1000$. Antes de serem observadas as lâminas foram deixadas no escuro em temperatura ambiente para estabilização dos corantes.

\subsubsection{Coloração com CMA/DA (Cromomicina A3/Distamicina)}

Após secagem das lâminas foram aplicados $25 \mu \mathrm{l}$ de uma solução de CMA diluída em tampão Mcllvaine ( $\mathrm{pH} 7,0)$ contendo $\mathrm{MgCl}_{2} 5 \mathrm{mM}$, na concentração de $0,5 \mathrm{mg} / \mathrm{ml}$, que foi coberta com lamínula de parafilme e mantida no escuro durante 2 horas. A seguir a lamínula foi removida e a lâmina lavada rapidamente em água deionizada, e posta para secar ao ar no escuro. Na lâmina seca foram aplicados $25 \mu \mathrm{l}$ de uma solução de DA diluída em tampão Mcllvaine ( $\mathrm{pH} 7,0$ ) na concentração de 0,2 $\mathrm{mg} / \mathrm{ml}$, coberta a seguir com lamínula de parafilme e mantida no escuro por 10 minutos. Novamente, retirou-se a lamínula e a lâmina foi lavada em água deionizada e posta para secar ao ar. Depois de seca a lâmina foi montada com $5 \mu \mathrm{l}$ de vectashield H-1000. Antes de serem observadas as lâminas foram deixadas no escuro em temperatura ambiente para estabilização dos corantes.

\subsubsection{Coloração seqüencial}

\subsubsection{Coloração seqüencial com CMA - CMA/DA}

Este tipo de coloração teve como objetivo diferenciar as heterocromatinas adjacentes à RON daquelas pericentroméricas. Ambos os tipos são observadas fluorescentes quando se preparam as metáfases apenas com CMA e podem ser diferenciadas após contracoloração com DA. 
Sobre a lâmina foram aplicados $25 \mu 1$ de uma solução de CMA diluída em tampão Mcllvaine ( $\mathrm{pH} 7,0$ ) contendo $\mathrm{MgCl}_{2} 5 \mathrm{mM}$, na concentração de $0,5 \mathrm{mg} / \mathrm{ml}$, que foi coberta com lamínula de parafilme e mantida no escuro durante 2 horas. A seguir a lamínula foi removida e a lâmina lavada rapidamente em água deionizada, e posta para secar ao ar no escuro. Depois de seca a lâmina foi montada com $5 \mu$ lde vectashield $\mathrm{H}$ 1000. Antes de serem observadas as lâminas foram deixadas no escuro em temperatura ambiente para estabilização dos corantes.

Após a analise das lâminas em microscópio de fluorescência, as lâminas foram desmontadas, removendo-se a lamínula com o auxilio de um estilete e uma pinça.

As lâminas foram lavadas em álcool absoluto duas vezes por 10 e 20 minutos e a seguir refixadas em Camoy.

Sobre a lâmina foram aplicados $25 \mu \mathrm{l}$ de uma solução de CMA diluída em tampão McIlvaine ( $\mathrm{pH} 7,0)$ contendo $\mathrm{MgCl}_{2} 5 \mathrm{mM}$, na concentração de $0,5 \mathrm{mg} / \mathrm{ml}$, que foi coberta com lamínula de parafilme e mantida no escuro durante 2 horas. A seguir a lamínula foi removida e a lâmina lavada rapidamente em água deionizada, e posta para secar ao ar no escuro.

Nas lâminas secas foram aplicados $25 \mu \mathrm{l}$ de uma solução de DA diluída em tampão Mcllvaine ( $\mathrm{pH} 7,0)$ na concentração de $0,2 \mathrm{mg} / \mathrm{ml}$, coberta a seguir com lamínula de parafilme e mantida no escuro por 10 minutos.

Novamente, retirou-se a lamínula e a lâmina foi lavada em água deionizada e posta para secar ao ar. Depois de seca a lâmina foi montada com $5 \mu$ de vectashield H-1000. Antes de serem observadas as lâminas foram deixadas no escuro em temperatura ambiente para estabilização dos corantes.

\subsection{Bandamento Ag-RON}

As lâminas foram coradas de acordo com o método descrito por Howell \& Black (1980) com algumas modificações.

As lâminas foram preparadas a partir de raízes frescas com não mais que dois dias de fixação. As lamínulas foram removidas com ácido acético a $45 \%$ e secas ao ar. Sobre a lâmina foram aplicadas duas gotas de uma solução de gelatina (Royal) a $2 \%$ em 
ácido fórmico a $1 \%$ de concentração final. Em seguida, duas gotas de uma solução de nitrato de prata a 50\%, foram adicionadas à lâmina. Cobriu- se com lamínula e incubouse em câmara úmida a $60{ }^{\circ} \mathrm{C}$, por um tempo variando de 5 a 10 minutos. $\mathrm{O}$ tempo ideal foi obtido monitorando a coloração através de observações ao microscópio. As lamínulas foram então removidas em água deionizada, as lâminas secas ao ar e montadas em bálsamo do Canadá.

\subsection{Hibridação in situ fluorescente (FISH)}

\subsubsection{Sondas}

Foram utilizadas como sondas a seqüência de rDNA 18S-5.8S-25S (unidade de 9,1 kb, que será mencionada como rDNA 45S) de milho, clonada no plasmídeo pUC8 no sítio Eco RI, cordialmente cedida pelo Dr. R. L. Phillips (University of Minesota, EUA) e o produto da reação de PCR que amplificou fragmentos do gene e espaçadores do rDNA de 5S de Crotalaria.

\subsubsection{Extração de DNA genômico total de espécies de Crotalaria pelo método do CTAB}

A extração de DNA genômico total foi realizada utilizando-se as espécies $C$. juncea, que pertence à mesma seção botânica das espécies poliplóides, e $C$. spectabilis pertencente a uma outra seção botânica. A extração seguiu o seguinte protocolo:

Uma amostra de folhas de cada uma das espécies foi macerada sob congelamento com nitrogênio liquido em cadinho de cerâmica. Em tubos falco foram colocados $500 \mathrm{mg}$ do macerado de folhas, adicionando-se $10 \mathrm{ml}$ de tampão CTAB a 65 ${ }^{0} \mathrm{C}$ (pré-aquecido) por amostra por 30 minutos, sendo misturado ocasionalmente. Ao retirar os tubos do banho-maria, foram adicionados $10 \mathrm{ml}$ de uma solução clorofórmio:etanol (24:1) (SEVAG). Homogeneizou-se rapidamente em vortex. Os tubos foram então centrifugados a $9500 \mathrm{rpm}$, por 10 minutos a $20{ }^{\circ} \mathrm{C}$. O sobrenadante foi transferido para tubos novos e adicionaram-se $500 \mu \mathrm{l}$ de isopropanol. O material foi homogeneizado por inversão do tubo. $O$ tubo foi deixado em repouso por 20 minutos e a seguir foi centrifugado a $9500 \mathrm{rpm}$, por 15 minutos a $20{ }^{\circ} \mathrm{C}$. O pellet foi lavado com 10 
$\mathrm{ml}$ de solução de lavagem por 20 minutos. O sobrenadante foi descartado, o tubo foi seco com lenço de papel e o pellet ressuspendido em $1 \mathrm{ml}$ de TE. Adicionou-se $500 \mu \mathrm{lde}$ acetato de amônia 7,5 M e 3,75 ml de etanol absoluto por amostra durante 30 minutos. Os tubos foram então centrifugados a $9500 \mathrm{rpm}$, por 10 minutos a $4{ }^{0} \mathrm{C}$. O pellet gelatinoso foi ressuspenso em $100 \mu \mathrm{l}$ de $\mathrm{TE}$, transferido para eppendorf e deixado a temperatura ambiente para dissolver. Essas amostras de DNAs foram utilizadas para amplificação do rDNA de $5 \mathrm{~S}$ a partir de uma reação de $\mathrm{PCR}$, para servirem como sondas para o mapeamento físico deste lóco nos cromossomos através de FISH.

\subsubsection{Amplificação do gene de RNA ribossômico 5S}

Os seguintes primers (sintetizados pela Life Technologies) foram utilizados para amplificar a seqüência de rDNA de 5S, via PCR, utilizando-se DNA de $C$. juncea e C. spectabilis:

RDNA1 (forward) 5' GTG CGA TCA CAG C(AG)(CT) TAA TGC ACC GG 3' RDNA2 (reverse) 5' GAG GAG CAA CAC GAG GAC TTC CAA GGA GG 3'

Na reação de PCR foram utilizados $10 \mathrm{ng}$ de DNA genômico de $C$. juncea ou C. spectabilis, $200 \mathrm{mM}$ de dNTPs, $300 \mathrm{nM}$ de cada primer, $1,5 \mathrm{mM}$ de $\mathrm{MgCl} 2$ e 2,5 U de Taq polimerase. As condições de PCR foram: incubação a $93^{\circ} \mathrm{C}$ por 5 min seguida por 30 ciclos de $94{ }^{\circ} \mathrm{C}$ por $50 \mathrm{seg}, 57^{\circ} \mathrm{C}$ por 50 seg e $72{ }^{\circ} \mathrm{C}$ por $1 \mathrm{~min}$, e $72{ }^{\circ} \mathrm{C}$ por 10 min. O produto obtido foi purificado utilizando-se os kits QIAquick PCR Purification (QIAGEN) ou NucleoSpin Extraction: PCR products (CLONTECH), seguindo os protocolos descritos pelos fabricantes.

Os produtos de amplificação foram submetidos à eletroforese em gel de agarose a $0,8 \%$, para confirmação e quantificação dos fragmentos amplificados. 


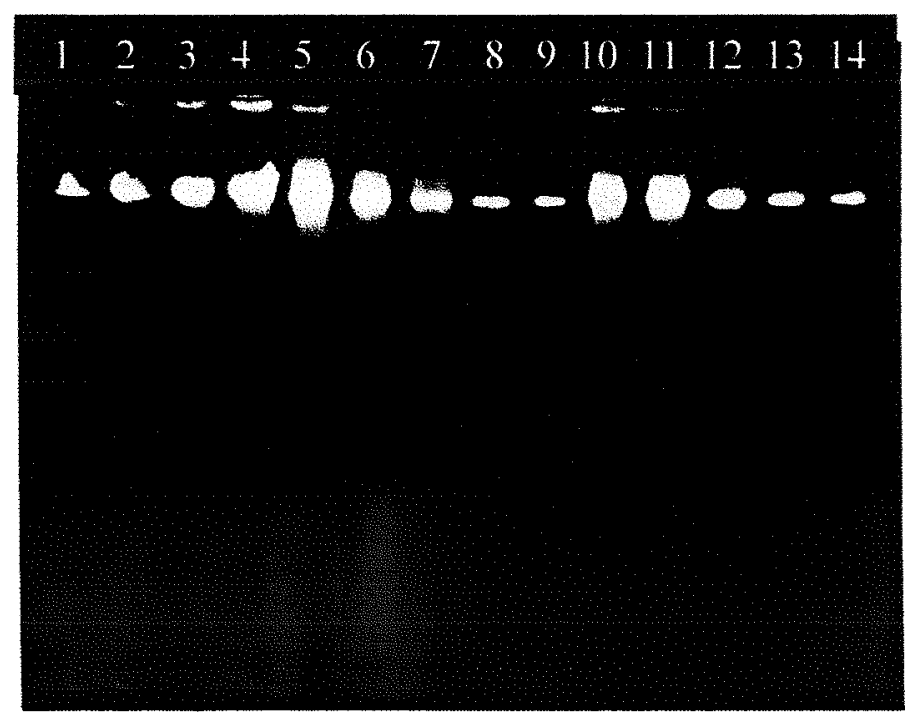

Figura 1: Extração e quantificação de amostras de DNA total de $C$. juncea utilizado nas reações de PCR, para amplificação do rDNA de 5S. Canaletas de 1 a $4 \lambda$ integro $1 \mu \mathrm{l}(50 \mathrm{ng}), 2 \mu \mathrm{l}$ (100 ng), $4 \mu \mathrm{l}$ (200ng) e $10 \mu \mathrm{l}$ (500ng); de 5 a 9 diluições do DNA extraído de uma amostra de folhas de $C$. juncea (total, $10^{-1}, 10^{-2}, 10^{-3}$ e $10^{-4}$, respectivamente); de 10 a 14 diluições de outra amostra de folhas de $C$. juncea (total, $10^{-1}, 10^{-2}, 10^{-3}$ e $10^{-4}$, respectivamente).

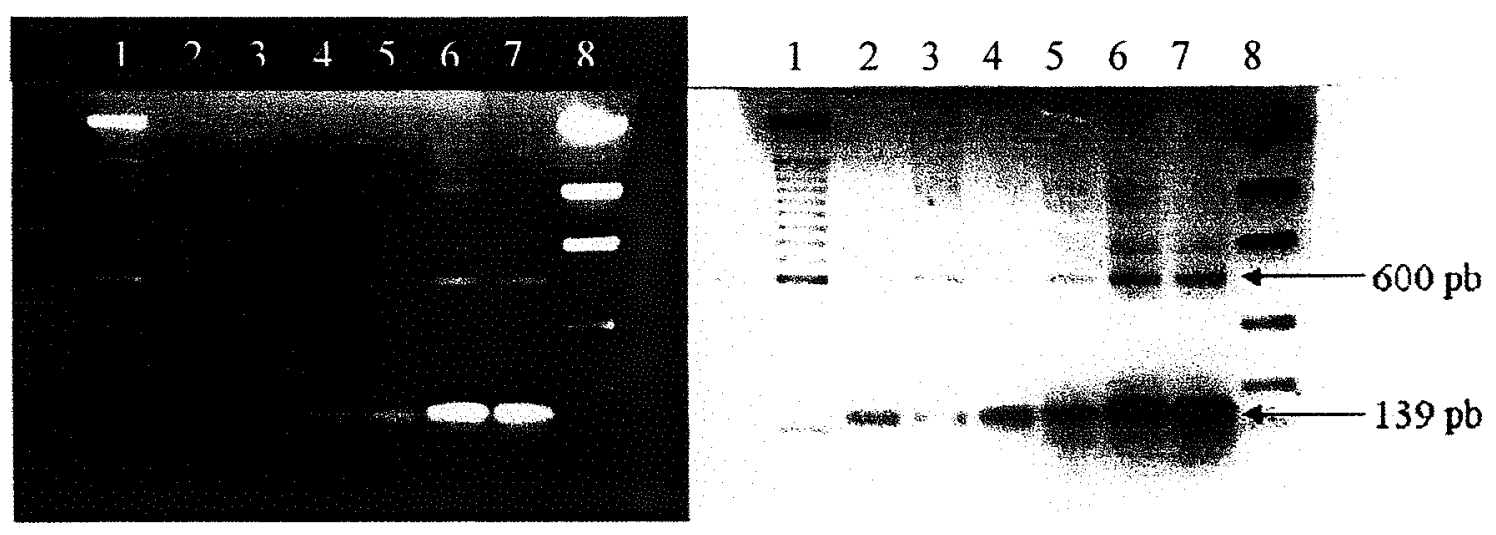

Figura 2: Produtos de amplificação do rDNA de 5S, caracterização e quantificação. Na canaleta 1 aparece o marcador Ladder de 100 pb e na 8 o marcador Low DNA Mass, as demais canaletas (2 a 7) são diferentes amostras de DNA de Crotalaria juncea. Observa-se a formação de duas bandas principais, uma maior de $600 \mathrm{pb}$ e outra menor de $139 \mathrm{pb}$. 


\subsubsection{Marcação das sondas e hibridação molecular in situ de sondas de DNA ribossomais $45 \mathrm{~S}$ e $5 \mathrm{~S}$}

Foram realizados dois tipos de experimentos de hibridação in situ, um utilizando-se apenas como sonda o rDNA 45S e outro utilizando-se como sondas o rDNA 45S e 5S (duplo-FISH).

As seqüências de DNA utilizadas como sondas foram marcadas com biotina via nick translation e digoxigenina via random primer respectivamente. As preparações cromossômicas foram preparadas para hibridação com a sonda marcada, através de lavagem com Rnase $(5 \mu \mathrm{g} / \mu \mathrm{l})$ e pepsina $(5 \mu \mathrm{g} / \mu \mathrm{l})$, para remoção do RNA e do excesso de proteínas respectivamente. As preparações cromossômicas foram então fixadas em paraformaldeído a $4 \%$ e desidratadas em uma série alcóolica (70\%, 96\% e 100\%). A mistura de hibridação consistiu de $50 \%$ formamida, $2 x \mathrm{SSC}, 10 \%$ dextran sulfato, $0,1 \%$ SDS, $1 \mathrm{mg} / \mathrm{ml}$ de "herring sperm DNA"e de 6 e $10 \mathrm{ng} / \mathrm{ml}$ de DNA das sondas de rDNA de $45 \mathrm{~S}$ e $5 \mathrm{~S}$, respectivamente para duplo-FISH, ou apenas $6 \mathrm{ng} / \mathrm{ml}$ do rDNA de $45 \mathrm{~S}$, nos experimentos com uma sonda. As sondas foram desnaturadas a $95-98^{\circ} \mathrm{C}$, por $10 \mathrm{~min}$ e imediatamente postas em gelo. Foram adicionados $20 \mu \mathrm{l}$ da mistura de hibridação às preparações cromossômicas. A mistura de hibridação já desnaturada e o DNA cromossômico foram aquecidos conjuntamente a $83{ }^{\circ} \mathrm{C}$ por $9 \mathrm{~min}$; então a temperatura foi gradualmente decrescida até $37^{\circ} \mathrm{C}$ utilizando-se um termociclador (PTC-100, MJ). A hibridação foi realizada a $37^{\circ} \mathrm{C}$ por $16 \mathrm{hs}$, seguida por lavagens em $2 x S S C$ a $42{ }^{\circ} \mathrm{C}$ por 5 minutos; duas lavagens com formamida a $20 \% / 0.5 \times$ SSC a $42{ }^{\circ} \mathrm{C}$ ( $74 \%$ de estringência) por 5 minutos; $0,5 x S S C 42{ }^{\circ} \mathrm{C}$ por 5 minutos. A sonda de rDNA de $45 \mathrm{~S}$ marcada com biotina foi detectada com o anticorpo "mouse anti-biotin" (Dako) seguido dos anticorpos "rabbit anti-mouse"-FITC na hibridação simples e -TRITC (Dako) no duplo-FISH e a sonda de rDNA 5S marcada com digoxigenina foi detectada com "sheep anti-digrodamine" (Roche). As preparações utilizando duplo FISH foram contra-coradas com DAPI (4,6-diamidino-2-phenylindole) a $0,2 \mu \mathrm{g} / \mathrm{ml}$ e as hibridações simples com iodeto de propidium (PI) a $50 \mu \mathrm{g} / \mu \mathrm{l}$; ambas montadas em $5 \mu \mathrm{l}$ de vectashield $\mathrm{H}-1000$. 


\subsection{Microscopia e análise de imagens}

As metáfases coradas pelo método de Feulgen e pelo bandamento-C, foram fotografadas em fotomicroscópio Zeiss, utilizando-se filme Technical Pan 225 ASA. As preparações fluorescentes foram observadas em microcópio de epifluorecência Zeiss Axiophot 2, no qual está acoplado uma câmara $\mathrm{CCD}$, que permitiu a digitalização das imagens através do programa ISIS (Metasystem).

Para a montagem das pranchas as fotomicrografias de Feulgen e Bandamento-C foram escaneadas com resolução de 300 dpi. As imagens digitalizadas das preparações fluorecentes foram pré-processadas no próprio programa ISIS. Todas as imagens foram processadas no programa Adobe PotoShop versão 6.0. 


\section{RESULTADOS}

\subsection{Estrutura dos cromossomos}

\subsubsection{Seção Calycinae}

\subsubsection{Crotalaria juncea}

$\mathrm{O}$ cariótipo de Crotalaria juncea é simétrico com cromossomos metacêntricos e submetacêntricos, com uma única constrição secundária no braço curto do cromossomo 1 (Oliveira \& Aguiar-Perecin, 1999). Os nossos resultados de coloração pelo método de Feulgen, servem para reforças esta observação (Figura 3a). Além disso, nenhuma outra constrição ou satélite é observado no complemento.

$\mathrm{O}$ bandamento-C revelou bandas nas regiões pericentroméricas de todos os cromossomos, e nas regiões adjacentes à constrição secundária do braço curto do cromossomo 1 (Figuras $3 \mathrm{~b}$ e $9 \mathrm{~b}$ ). Foi possível visualizar-se que as regiões intensamente coradas pelo bandamento- $\mathrm{C}$, no cromossomo 1, estão localizadas somente no braço curto, adjacentes à constrição secundária e em posição pericentromérica. $\mathrm{O}$ par de cromossomos 4 , identificável pela posição mais subterminal do centrômero, apresenta uma banda-C maior que a dos demais cromossomos, e esta banda-C está localizada no braço longo. Nos demais cromossomos, aparentemente blocos heterocromáticos são pericentroméricos e estão localizados nos dois braços cromossômicos. Em algumas preparações pôde ser observado algumas bandas-C terminais, entretanto estas não apareciam de forma constante, não sendo possível a sua caracterização precisa.

As observações de preparações coradas apenas com CMA revelaram um padrão de bandas fluorescentes, semelhante aquele observado no bandamento-C (Figura 3c). 
Todas as heterocromatinas pericentroméricas e as adjacentes à região organizadora do nucléolo apresentaram fluorescência intensa. Um pequeno sítio fluorescente pôde ser observado no braço longo do cromossomo 1 (Figura 3c). Este sítio não é visualizado em preparações pelo método de bandamento-C. Esta observação indica que estas heterocromatinas são ricas em GC, uma vez que a cromomicina $A_{3}$ é específica para estes nucleotídeos (Schweizer 1976a).

A combinação do fluorocromo primário CMA e do contra-corante DA, não fuorescente, permitiu uma diferenciação entre as bandas CMA positivas. Neste caso, as regiões pericentroméricas apareceram com fluorescência reduzida. As heterocromatinas adjacentes à constrição secundária apresentaram fluorescência intensa, assim como o sítio no braço longo deste mesmo cromossomo (Figuras 3d e 10c). Entre estas duas regiões fluorescentes, aparece uma região com fluorescência reduzida correspondente à heterocromatina pericentromérica. Do mesmo modo, o cromossomo 4 apresentou uma diferenciação de sua heterocromatina. A região heterocromática deste cromossomo podia ser observada como uma única banda-C, e um único sítio de CMA, entretanto a combinação de CMA/DA permitiu observar que esta região é subdividida. $\mathrm{Na}$ região pericentromérica é observado uma fluorescência reduzida, e adjacente a esta uma banda fluorescente, assim como foi descrito para o cromossomo 1.

As colorações específicas para nucleotídeos AT, DAPI e DAPI/AMD, não revelaram fluorescência em nenhuma região cromossômica (Figura 3e). Todas as regiões heterocromáticas anteriormente descritas, mostraram fluorescência reduzida, sendo facilmente visualizado no cromossomo 1 , que apresenta a maior região negativa. $\mathrm{Na}$ coloração com DAPI e DAPI/AMD, não é possível uma rápida identificação do cromossomo 4. Estes dados reforçam que as regiões heterocromáticas de C. juncea são compostas de seqüências ricas em GC.

A hibridação da sonda contendo o DNA para os genes ribossomais de 18S5.8S-26S (rDNA 45S) apresentou sítios na constrição secundária do cromossomo 1 e nas suas heterocromatinas adjacentes, como era esperado (Figura $3 \mathrm{f}$ ). Nenhum outro sítio foi observado neste cromossomo. Um sítio adicional de rDNA 45S foi observado no cromossomo 4 (Figura 3f). Os sítios de rDNA correspondem exatamente às regiões 
heterocromáticas fluorescentes com CMA/DA. A contra-coloração com PI permite a visualização das heterocromatinas com o padrão de banda-C (Figura 3f). Neste caso fica claro que, no cromossomo 1 existe realmente uma divisão na heterocromatina proximal, sendo que a região adjacente à constrição secundária é composta por seqüências de rDNA 45S, enquanto que a pericentromérica não apresenta estas seqüências. Esta mesma organização é observada no cromossomo 4 , sendo que neste cromossomo o centrômero aparece como uma região negativa, quando contra-corado com PI, a heterocromatina pericentromérica aparece com fluorescência positiva e adjacente a ela aparece o sítio de rDNA de 45S (Figura 3f). A observação apenas do contra-corante, confirma que esta região heterocromática do cromossomo 4 , aparece como uma única banda fluorescente, como foi anteriormente descrito para o bandamento-C. O cromossomo 4 é melhor identificado em prometáfases, através da coloração fluorescente CMA/DA ou com a hibridação de sondas do rDNA de $45 \mathrm{~S}$, sendo estes excelentes marcadores para este cromossomo. A hibridação dupla com as sondas de rDNA de $45 \mathrm{~S}$ e 5S mostrou que este último esta localizado em apenas um lóco no braço longo do cromossomo 1(Figuras $3 \mathrm{~g}$ e $10 \mathrm{c}$ ), correspondente ao sítio CMA/DA anteriormente descrito para esta posição, não identificável pelo bandamento-C. O rDNA de 5S semelhantemente ao rDNA de $45 \mathrm{~S}$ é composto por seqüências ricas em GC.

A coloração com nitrato de prata mostra que os genes de rDNA de $45 \mathrm{~S}$ do cromossomo 1 são os principais organizadores do nucléolo, o que já era esperado, devido à presença da constrição secundária neste cromossomo (Figura 4a). O cromossomo 4, entretanto, as vezes apresenta marcação pelo nitrato de prata e outras vezes não (Figuras 4a-b), mas este nunca apresenta qualquer tipo de constrição.

\subsubsection{Crotalaria stipularia}

A observação de metáfases coradas pelo método de Feulgen desta espécie poliplóide com $2 \mathrm{n}=32$ cromossomos revela apenas um par de cromossomos com constrição secundária (Figura 5a), como observado anteriormente por Oliveira \& Aguiar-Perecin (1999). O bandamento-C mostra que os cromossomos possuem bandas heterocromáticas nas regiões pericentroméricas, nas regiões adjacentes à constrição 
secundária e em alguns casos bandas nas posições terminais, embora pelo seu pequeno tamanho, não sejam detectáveis em todas as células analisadas (Figuras 5b e 9d) Do mesmo modo como ocorre em $C$. juncea, essas heterocromatinas terminais por não serem constantes, não foram consideradas no presente estudo.

A coloração com CMA mostrou um padrão de bandas semelhante aquele observado pelo bandamento-C. Observa-se claramente, as regiões heterocromáticas fluorescentes correspondentes às pericentroméricas e as adjacentes à RON, não sendo observado nenhum sítio fluorescente em posições terminais, ou em qualquer outra posição intersticial ou proximal. A coloração com CMA/DA diferenciou bandas com fluorescência intensa nas heterocromatinas adjacentes à constrição secundária no cromossomo 1 e também em um outro par de cromossomos na posição adjacente à região pericentromérica, tal como foi observado para $C$. juncea (Figura 5c). Consideramos este par de cromossomo adicional como correspondente ao cromossomo 4 de $C$. juncea, como será discutido mais adiante. Estes quatro sítios diferenciados pela coloração com $\mathrm{CMA} / \mathrm{DA}$, são considerados muito ricos em GC em relação aos demais sítios observados apenas com a coloração com CMA. As colorações com DAPI e DAPI/AMD não revelaram bandas fluorescentes, apenas regiões de fluorescência reduzida, correspondentes às heterocromatinas pericentroméricas e às da constrição secundária (Figura 5e), o que confirma o pressuposto de que essas regiões sejam ricas em GC. Estes resultados são muito semelhantes aos observados em $C$. juncea, e servem como parâmetro de comparação entre as duas espécies.

A análise de metáfases hibridizadas com a sonda de rDNA de 45S, revelaram a presença de sinais de hibridação no cromossomo 1, como esperado por conter a região organizadora do nucléolo e em um outro par de cromossomos (Figuras $5 \mathrm{f} \mathrm{e} \mathrm{10e).} \mathrm{No}$ cromossomo 1 pôde-se observar o sinal ocupando a constrição secundária e as heterocromatinas adjacentes, com um padrão muito idêntico ao observado em $C$. juncea . O outro par de cromossomos com um sítio de rDNA corresponde ao par que possui uma banda CMA/DA. O sítios de hibridação da sonda de rDNA de 45S e a banda CMA/DA fluorescente estão localizadas no braço curto deste par de cromossomos, enquanto em $C$. juncea este sítio está situado no braço longo. Mesmo assim, pela morfologia destes 
cromossomos eles podem ser considerados homeólogos, sendo que em $C$. stipularia poderia ter ocorrido uma inversão pericêntrica em relação a $C$. juncea.

Não foi possível o mapeamento físico do lóco de rDNA de $5 \mathrm{~S}$, provavelmente pelo tamanho muito pequeno do sítio. No experimento para mapear este lóco, foi utilizada apenas uma amplificação do sinal da sonda, o que pode não ter sido suficiente para sua visualização ao microscópio. Em um experimento futuro será utilizada uma sonda de rDNA de $5 \mathrm{~S}$ biotinilada, o que permitirá uma amplificação do sinal de hibridação com o uso de três anticorpos, o que aumenta as chances de visualização do sinal de hibridação.

\subsubsection{Crotalaria paulina}

A coloração pelo método de Feulgen mostra que, esta espécie poliplóide com $2 n=32$ cromossomos possui apenas um par com constrição secundária, conforme relato anterior (Oliveira \& Aguiar-Perecin, 1999) (Figura 6a). O bandamento-C revelou um pardrão de banda pericentromérico (Figuras $6 \mathrm{~b}$ e 9c)e com bandas adjacentes à constrição secundária, bandas-C terminais são de difícil observação e aparecem de modo muito inconstante, como é observado para outras espécies desta seção.

As heterocromatinas pericentroméricas e adjacentes à constrição secundária são fluorescentes com CMA (Figura 6c), indicando sua natureza rica em GC, entretanto com a aplicação de CMA/DA as regiões pericentroméricas deixam de ser fluorescentes, sendo diferenciados três pares de cromossomos (Figura $6 \mathrm{~d}$ e $10 \mathrm{~d}$ ). $\mathrm{O}$ cromossomo 1 que apresenta a constrição secundária, apresenta fluorescência intensa, um segundo par de cromossomos apresenta uma região com fluorescência intensa e adjacente à região pericentromérica com fluorescência reduzida, a fluorescência parece ocupar uma grande região do braço curto deste cromossomo, sendo sua morfologia muito parecida com a do cromossomo 1 e um terceiro par de cromossomos apresenta um sinal fluorescente no braço longo na região adjacente ao centrômero, porém este cromossomo é menor que os outros dois pares marcados. Este último par, apresenta morfologia muito semelhante ao par de cromossomos 4 de $C$. juncea e também ao cromossomo com marcação adicional observado em $C$. stipularia. A coloração com DAPI e DAPI/AMD não apresentaram 
bandas fluorescentes (Figura 6d). Todas as regiões heterocromáticas aparecem com fluorescência reduzida, tanto nas regiões pericentroméricas, quanto nas regiões adjacentes à constrição secundária. Estes resultados reforçam a evidência de que estas regiões devem ser muito ricas em GC.

A hibridação in situ com a sonda de rDNA de $45 \mathrm{~S}$ confirmou que estas regiões fluorescente com CMADA, correspondem a sítios ribossomais. Entretanto, dificilmente os seis sítios aparecem com sinais, à contagem mais comum foram de cinco sinais de hibridação (Figura $6 \mathrm{f}$ e $10 \mathrm{~d}$ ). Isto pode ser devido ao tamanho reduzido do sítio. Foi observado, que o sinal de hibridação do sítio de rDNA de 45S no cromossomo menor, é muito fraco, mesmo em prófases mitóticas. O cromossomo 1 com a constrição secundária é marcado como esperado, o segundo par de cromossomos é grande e com morfologia muito semelhante a do cromossomo 1, como descrito anteriormente e possivelmente é o seu homeólogo e do mesmo modo o cromossomo com o sinal menor no braço curto, tem morfologia muito parecida com a do cromossomo 4 de $C$. juncea, sendo este seu provável homeólogo (Figura 10). Estas regiões nunca aparecem como constrições secundárias, exceto o cromossomo 1 com a constrição secundária, indicando que elas devem estar inativas ou apresentam atividade em outras fases do desenvolvimento da planta.

Do mesmo modo como ocorreu em $C$. stipularia, não foi possível o mapeamento do lóco de rDNA de 5S. As razões pelo qual isto não foi possível, foram discutidas anteriormente.

\subsubsection{Seção Crotalaria, sub-seção Crotalaria}

\subsubsection{Crotalaria spectabilis}

Esta espécie é a única que possui a constrição secundária no braço longo do cromossomo 1 (Oliveira \& Aguiar-Perecin, 1999), o que é facilmente observado em preparações pelo método de Feulgen (Figura 7a). O método de bandamento-C revelou bandas pericentroméricas em todos os cromossomos e não é claro a presença de possíveis bandas terminais (Figura $7 \mathrm{~b}$ ). As regiões heterocromáticas adjacentes à 
constrição secundária aparecem como bandas-C (Figura 7b), embora todos os cromossomos apresentem bandas pericentroméricas nítidas, a do cromossomo 1 é particularmente difícil de ser observada. Em muitas metáfases, a região pericentromérica do cromossomo 1 não apresenta coloração pelo corante de Giemsa após o tratamento para o bandamento- $\mathrm{C}$, sendo possível a observação de apenas uma banda- $\mathrm{C}$ pequena adjacente à constrição secundária (Figuras7b e 9a). Entretanto, como será descrito a seguir a região heterocromática pericentromérica do cromossomo 1 está presente e pode ser diferenciada da heterocromatina adjacente à constrição secundária.

A coloração com fluorocromos feita de modo seqüencial, CMA - CMA/DA diferenciou as heterocromatinas adjacentes a RON das pericentroméricas (Figuras 7c e d), do mesmo modo que para as espécies da seção Calycinae. Neste caso as heterocromatinas adjacentes à constrição secundária apresentaram fluorescência intensa para coloração com CMA e CMA/DA (Figuras 7c e d), sendo que para a coloração com CMA todas as regiões pericentroméricas dos demais cromossomos apresentaram fluorescência intensa, enquanto que para o $\mathrm{CMA} / \mathrm{DA}$ apresentaram fluorescência reduzida. No cromossomo 1 é possível observar que a banda fluorescente adjacente à constrição secundária e próxima ao centrômero é ligeiramente maior quando corada apenas com o CMA, do que quando corada com CMA/DA, indicando assim a presença da heterocromatina pericentromérica, que não fluoresce intensamente com CMA/DA, também neste cromossomo. As colorações com DAPI e DAPI/AMD não revelaram bandas fluorescentes em C. spectabilis (Figura 7e), entetanto, diferentemente das outras espécies, não há regiões de fluorescência reduzidas nítidas, exceto para a constrição secundária do cromossomo 1. Em muitas metáfases submetidas à hibridação molecular fluorescente in situ e contra-coradas com DAPI, é possível observar um padrão de bandas semelhante ao bandamento-C e ainda a visualização de fluorescência nas extemidades dos cromossomos, entretanto isto poderia ser considerado como resultado do processo de desnaturação-renaturação dos cromossomos e não podem ser confundidas como regiões de DNA rico em AT.

Os experimentos com a sonda de rDNA de $45 \mathrm{~S}$ revelam que apenas o cromossomo 1 possuí a seqüência codificadora dos rRNAs e que estas estão localizadas 
na constrição secundária e nos blocos de heterocromatina adjacentes (Figura $7 f$ e 10b). De modo muito interessante, a contra coloração com iodeto de propídio revelou um padrão de bandas semelhante ao do bandamento-C, nestas preparações. Este padrão de bandas permitiu a comparação entre o tamanho da banda e a extensão do sinal de hibridação. Observa-se que o sítio de rDNA não ocupa toda a região heterocromática revelada pelo iodeto de propídio, sendo que na região mais próxima ao centrômero é claramente observado a fluorescência do iodeto de propídio, que corresponde à heterocromatina pericentromérica do cromossomo 1 (Figuras $7 f$ e 10b). Este mesmo padrão de diferenciação é observado em $C$. juncea, indicando uma relação estreita entre a estrutura dos cromossomos destas espécies, apesar de estarem em grupos botânicos distintos.

A hibridação com sonda dos rDNAs de $45 \mathrm{~S}$ e $5 \mathrm{~S}$ permitiu um mapeamento detalhado destes sítios (Figura 10b). O lóco de rDNA de 5S está localizado no braço longo do cromossomo 1 junto à heterocromatina adjacente à constrição secundária que ocupa a posição mais distal do braço (Figura 7g). Por esta localização tão próxima é que não foi possível a diferenciação deste lóco na forma de uma banda CMA/DA fluorescente, como é observado no braço longo de C. juncea. Certamente, pela sua posição muito próxima à heterocromatina adjacente à constrição secundária as duas regiões apareçam como uma única banda CMA/DA fluorescente. O mapeamento destes marcadores cromossômicos permite claramente observar que $C$. spectabilis possui uma inversão pericêntrica em relação a $C$. juncea. Os pontos de quebra ocorreram provavelmente em um loco adjacente ao centrômero e o final da heterocromatina adjacente à constrição secundária na posição distal, sendo que a posição do loco de rDNA de 5S manteve-se conservado nas duas espécies.

\subsubsection{Seção Chrysocalycinae, sub-seção Incanae}

\subsubsection{Crotalaria incana}

A espécie $C$. incana é a única com 2 n=14 cromossomos (Palomino e Vázquez, 1992, Oliveira \& Aguiar-Perecin, 1999). De acordo com as últimas autoras é a espécie 
com um dos maiores comprimentos de lote haplóide, e conseqüentemente apresentam os maiores cromossomos. A análise morfométrica dos cromossomos desta espécie corados pelo método de Feulgen confirmaram as observações anteriores de Oliveira \& AguiarPerecin (1999), observando-se apenas um par de cromossomos com constrição secundária (Figura 8a).

Em preparações coradas pelo bandamento-C não se observaram blocos de heterocromatina corados intensamente (Figura $8 b$ ). As regiões pericentroméricas não se mostraram intensamente coradas, do mesmo modo que as regiões adjacentes à constrição secundária, onde seriam esperadas bandas- $\mathrm{C}$, tal como foi descrito para as demais espécies. Em seu estudo Oliveira (1992) havia descrito que após a aplicação da metodologia de bandamento- $\mathrm{C}$, os núcleos desta espécie apareciam sem qualquer tipo de cromocentros, e que nas metáfases não foi possível à observação de bandas-C.

Preparações coradas com o fluorocromo CMA e CMA/DA apresenta marcações fluorescentes na heterocromatina adjacente à constrição secundária, distal e proximal e na região terminal do braço curto do cromossomo 1 (Figura 8c) e este sítio distal não é facilmente observado em metáfases muito contraídas, sendo mais visível em prófases e prometáfases e não foi detectado nas outras espécies. Também nestas fases, é possível um detalhamento da constrição secundária. A região pericentromérica não apresenta fluorescência e a heterocromatina adjacente à constrição secundária na região proximal apresenta fluorescência intensa. Esta banda fluorescente não é facilmente observada em metáfases muito contraídas. Na região distal à constrição secundária há outra banda fluorescente, também de difícil observação. Em algumas metáfases estas bandas aparecem fundidas, devido a não distensão da constrição secundária, ainda assim o sinal fluorescente é muito pequeno, principalmente quando comparado com as outras espécies do gênero. Nas fases de prófase e prometáfase a banda fluorescente distal do braço curto é mais facilmente visualizada. As regiões pericentroméricas não apresentaram fluorescência nesta espécie, diferindo totalmente das demais. Existem ainda duas marcas fluorescentes com CMA e CMA/DA em regiões intersticiais dos braços curto e longo do cromossomo 3, entretanto estes sítios são muito pequenos e de difícil observação. 
As colorações fluorescentes DAPI e DAPI/AMD revelaram bandas fluorescentes dispersas nos cromossomos (Figuras 8d e 10a). As regiões pericentroméricas aparecem na sua maioria sem fluorescência. Apenas o par de cromossomos 4 apresenta fluorescência pericentromérica, o que torna este sítio fluorescente um excelente marcador para este cromossomo. O par de cromossomos 1 possui um sítio fluorescente adjacente ao centrômero e este é separado da constrição secundária por uma região de cromatina não fluorescente. Na ponta do braço curto do cromossomo 1, há um sinal fluorescente, que não corresponde aquele observado com CMA e CMA/DA. Outros cromossomos apresentam sítios DAPI/AMD fluorescentes dispersos. $\mathrm{O}$ cromossomo 2 apresenta sítios nos terminais do braço curto e longo, além de um sítio intersticial no braço longo. O cromossomo 3 apresenta somente sítios fluorescentes com DAPI e DAPI/AMD nas posições terminais de cada braço. O cromossomo 4 apresenta sítios fluorescentes nas posições terminais de cada braço, além de um sítio fluorescente na região pericentromérica, como anteriormente descritos. $\mathrm{O}$ cromossomo 5 possuí apenas um sítios fluorescente em posição intersticial do braço longo. $\mathrm{O}$ cromossomo 6 possuí dois sítios fluorescentes no braço longo, um em posição intersticial e outro na posição terminal. $\mathrm{O}$ cromossomo 7 é o único que não apresenta marcas fluorescentes. Este padrão de bandas DAPI/AMD fluorescentes, representam um excelente marcador para a identificação de cada um dos cromossomos de $C$. incana. Curiosamente em relação às outras espécies, os sítios fluorescentes terminais em $C$. incana foram constantes e de identificação consistente e com repetibilidade. Seria esperado que o bandamento-C revelasse estas regiões heterocromáticas, entretanto isto não foi observado pela metodologia utilizada, provavelmente por serem estas regiões muito pequenas.

A hibridação in situ com as sondas de DNAs ribossômicos de $45 \mathrm{~S}$ e $5 \mathrm{~S}$ revelaram mais marcadores interessantes nesta espécie. O rDNA de $45 \mathrm{~S}$ foi mapeado utilizando-se a sonda marcada com biotina o que permitiu a amplificação de três vezes do sinal, sendo possível o mapeamento de sítios menores destes genes (Figuras 8e e 10a). Como esperado, o cromossomo 1 apresentou sítios correspondente à constrição secundária e nas heterocromatinas adjacentes. Além deste dois outros sítios foram 
mapeados, um no cromossomo 4 em posição subterminal, adjacente ao sítio fluorescente com DAPI ou DAPI/AMD; o cromossomo 5 apresenta um sítio de rDNA de 45S na posição terminal do braço curto. A sonda de rDNA de $5 \mathrm{~S}$ revelou sinal no braço longo do cromossomo 3, em posição correspondente ao sítios fluorescente com CMA ou CMA/DA, da mesma forma que foi observado para as outras espécies. Estes sítios de rDNA representam marcadores muito importantes no estudo comparativo entre as espécies e ainda, a combinação destas diferentes metodologias, permitiu um mapeamento detalhado de cada cromossomo de C. incana (Figura 10).

\subsection{Marcadores cromossômicos e a subdivisão do gênero Crotalaria em seções}

Os idiogramas de bandamento-C e o mapa físico com a posição dos sítios fluorescentes para as colorações com fluorocromos e para sítios de hibridação de sondas de rDNAs de $45 \mathrm{~S}$ e 5S, estão sumarizados no Quadro 2 e podem ser visualizados nas

figuras 9 e 10 respectivamente. Na quadro 2 é apresentado um resumo dos marcadores cromossômicos descritos anteriormente.

A caracterização de estruturas dos cromossomos de espécies de Crotalaria, permitiu uma visualização dos possíveis processos evolutivos envolvidos na especiação do gênero. A espécie $C$. juncea, foi a espécies referencial neste trabalho, por ter sido a primeira estudada e também por ter a maior importância agrícola. Esta espécie como visto anteriormente possui um sítio adicional de rDNA de $45 \mathrm{~S}$ no braço longo do cromossomo 4. De acordo com a observação de preparações coradas pelo nitrato de prata, este sítio aparentemente tem uma atividade parcial muito fraca e pode ser expresso de modo mais significativo em outros estágios do desenvolvimento da planta. Em núcleos interfásicos foi possível a observação de micronucléolos (dados não apresentados).

Quanto as espécies poliplóides, algumas considerações são importantes: 1. As características cromossômicas das espécies poliplóides são coerentes com sua classificação taxonômica juntamente com $C$. juncea, o que pode nos permitir assumir que as espécies ancestrais desses poliplóides originados por auto ou alopoliploidia, seriam muito semelhantes a espécie $C$. juncea, como será discutido. 2. As observações 
dos sítios ribossômicos nestes poliplóides dão algumas informações interessantes para a investigação de sua origem através de auto ou alopoliploidia. O número de sítios de rDNA 45S não são correspondentes ao grau de poliploidia desses poliplóides, sendo que em C. paulina são observados 6 sítios, enquanto $C$. stipularia apresenta 4 sítios de rDNA 45S.

Quadro 2: Número e natureza dos marcadores cromossômicos descritos para espécies de Crotalaria

\begin{tabular}{|c|c|c|c|c|c|c|c|c|}
\hline \multirow[b]{2}{*}{ Espécies } & \multirow[b]{2}{*}{$2 n$} & \multirow[b]{2}{*}{ C.S } & \multicolumn{2}{|c|}{ FISH } & \multicolumn{2}{|c|}{ Bandas CMA/DA } & \multicolumn{2}{|c|}{ Bandas } \\
\hline & & & $45 \mathrm{~S}$ & 5S & $45 \mathrm{~S}$ & $5 \mathrm{~S}$ & Centroméricas & Term./Inters. \\
\hline \multicolumn{9}{|c|}{ Seção Calycinae } \\
\hline C. juncea & 16 & 2 & 4 & 2 & + & + & $\mathrm{CMA}+/ \mathrm{DAPI}-$ & - \\
\hline C. paulina & 32 & 2 & 6 & nd & + & - & $\mathrm{CMA}+/ \mathrm{DAPI}-$ & - \\
\hline C. stipularia & 32 & 2 & 4 & nd & + & - & $\mathrm{CMA}+/ \mathrm{DAPI}-$ & - \\
\hline \multicolumn{9}{|c|}{ Seção Crotalaria } \\
\hline \multicolumn{9}{|c|}{ Sub-seção Crotalaria } \\
\hline C. spectabilis & 16 & 2 & 2 & 2 & + & +1 & CMA+/DAPI- & - \\
\hline \multicolumn{9}{|c|}{ Seção Chrysocalycinae } \\
\hline \multicolumn{9}{|c|}{ Sub-seção Incanae } \\
\hline \multirow[t]{2}{*}{ C. incana } & 14 & 2 & 6 & 2 & + & + & CMA- & DAPI + \\
\hline & & & & & & & DAPI $+^{2}$ & $\mathrm{CMA}+{ }^{3}$ \\
\hline
\end{tabular}

C.S. - número diplóide de constrições secundárias.

Term./Inters. - Posições terminais e intersticiais.

nd - não detectado, provavelmente devido ao seu pequeno tamanho.

${ }^{1}$ Não é possível diferenciar este sítio devido a proximidade entre os rDNAs de $45 \mathrm{~S}$ e $5 \mathrm{~S}$.

${ }^{2}$ Somente no cromossomo 4.

${ }^{3}$ Somente na posição terminal do braço longo do cromossomo 1 e em posições intersticiais dos braços curto e longo do cromossomo 3.

$\mathrm{Na}$ espécie $C$. paulina o par de cromossomos classificado como número 2 , seria homeólogo do par 1 de C. juncea ou de um ancestral semelhante e nele teria ocorrido perda parcial de seqüências de rDNA 45S e ainda ocorreria dominância nucleolar entre estes dois pares de cromossomos, assunto que será discutido mais adiante. O cromossomo identificado como par 8, portador de um sítio de rDNA 45S, seria homeólogo do par 4 de $C$. juncea ou de um ancestral relacionado com esta espécie, mas 
teria havido perda total das seqüências ribossomais em outro par correspondente, seja esta espécie de origem auto ou alopoliplóide (Fig. 10 e Quadro 2). $\mathrm{Na}$ espécie $C$. stipularia o par de cromossomos que seria homeólogo do cromossomo 1 perdeu totalmente as seqüências ribossomais, do mesmo modo o cromossomo identificado como par 8, portador de um sítio de rDNA 45S, seria homeólogo do par 4 de $C$. juncea ou de um ancestral relacionado, entretatanto, tal como ocorreu para $C$. paulina o outro par de cromossomos correspondente teria perdido toda a seqüência de rDNA 45S.

Pode-se, portanto, concluir que estas espécies estão sofrendo um estado de reversão da poliploidia, voltando ao estado diplóide pelo menos do ponto de vista citológico. Neste caso, a espécie $C$. paulina estaria em um estagio intermediário deste processo em relação a espécie $C$. stipularia que teria atingido o estágio máximo de diploidização. Reforçando esta hipótese, está o fato da dificuldade de observação do sítio de rDNA de $45 \mathrm{~S}$ nos dois homólogos do par 8 de $C$. paulina, sendo que em muitos casos foram contados apenas cinco sítios de hibridação da sonda de rDNA 45S.

Em relação as demais estruturas cromossômicas estas três espécies mostraram semelhanças. A posição das bandas- $\mathrm{C}$ e sua natureza com relação ao conteúdo de GC e AT determinado pelo uso de fluorocromos específicos (Figuras 9 e 10), mostram que elas tem origem semelhantes. Resta ainda para completar a seção Calycinae, o mapeamento do rDNA de 5S para observar se há uma colinearidade deste marcador entre a espécie diplóide e as poliplóides.

A espécie $C$. spectabilis, pertencente à seção Crotalaria, difere das espécies da seção Calycinae, principalmente pelo fato de não apresentar sítios adicionais de rDNA de 45S (Quadro 2 e Figura 10). Como foi observado e descrito anteriormente, $C$. spectabilis, apresenta apenas um sítio de rDNA de $45 \mathrm{~S}$ no braço longo do cromossomo 1, na região da constrição secundária e heterocromatinas adjacentes. Comparando-se esta espécie, com o representante diplóide da seção Calycinae, $C$. juncea, fica claro que C. spectabilis possui uma inversão pericêntrica no cromossomo 1. Observa-se claramente que a posição do rDNA de 5S se manteve colinear entre as duas espécies, entretanto a heterocromatina pericentromérica e o sítios e rDNA de $45 \mathrm{~S}$ se alteraram em relação à posição do centrômero, sendo que os rDNAs de $45 \mathrm{~S}$ e $5 \mathrm{~S}$ passaram a ser quase 
co-localizados, não sendo possível a separação com a coloração CMA/DA de um sítio fluorescente correspondente ao rDNA de 5S, tal como foi observado em $C$. juncea.

As demais estruturas cromossômicas, tal como as bandas- $\mathrm{C}$ e sua natureza com relação ao conteúdo de $\mathrm{GC}$ e $\mathrm{AT}$, foram semelhantes entre as seções Calycinae e Crotalaria, sendo possível sua separação somente pelo número de sítios de rDNA de 45S (Figuras 9 e 10). Na figura 11 os cariótipos das cinco espécies estão organizados em um esquema de relações filogenéticas proposto por Polhill (1982). De modo muito interessante, as seções Calycinae e Crotalaria correspondem às que têm flores mais especializadas. Diferindo totalmente destas duas seções botânicas, está a espécie $C$. incana, perencente a seção Chrysocalycinae - subseção Incanae. Esta espécie com $2 \mathrm{n}=14$, além dos cromossomos maiores e mais assimétricos (Oliveira \& Aguiar-Perecin, 1999), não possui bandas-C pericentroméricas, possui apenas dois sítios CMA positivos que não correspondente a sítios de rDNAs e a maioria de seus sítios fluorescentes são ricos em AT (Quadro 2 e Figura 10). Além disso, o número de sítios de rDNA de 45S é maior do que o observado em $C$. juncea. A localização dos sítios de rDNA de 5S não é colinear ao observado em $C$. juncea e $C$. spectabilis, onde este sítio é colinear (Figura $10)$.

Botanicamente a espécie $C_{i}$ incana está muito distante das demais espécies com relação à sua especialização floral. $C$. incana está localizado no grupo com flores sem estruturas de especialização floral (Figura 11).

Estas primeiras espécies estudadas a partir de técnicas de bandamento-C, coloração com fluorocromos e hibridação de sondas de rDNAs de 45S e 5S, permitem a visualização de ganhos e perdas de seqüências repetitivas durante a evolução e a especialização destas espécies, como será discutido mais adiante. 


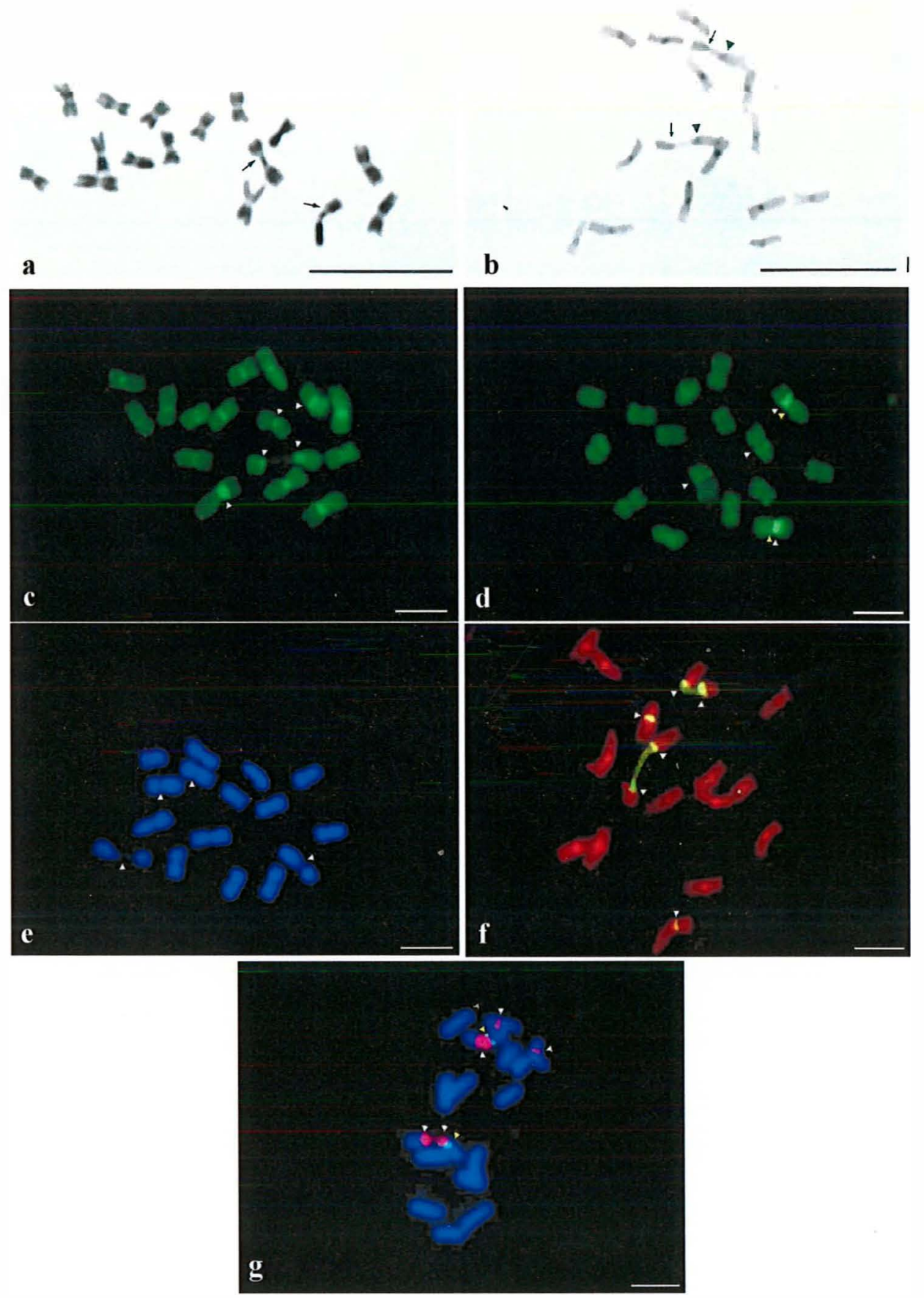

Figura 3 - Crotalaria juncea - seção Calycinae $-2 n=16$. (a) Metáfase corada pelo método de Feulgen. (b) Metáfase corada pelo método do bandamento-C: identificam-se bandas pericentroméricas e adjacentes à constrição secundária. (c) Coloração com CMA mostrando o mesmo padrão de bandas visto em b. (d) Coloração CMA/DA. (e) Coloração DAPI/AMD mostrando apenas regiões pericentroméricas e a constrição secundária negativas. (f) FISH com a sonda de rDNA 45S: vêem-se sítios de hibridação nos cromossomos 1 e 4. (g) FISH com sondas de rDNA de 45S (vermelho) e 5S (verde), observa-se apenas marcação de 5S no braço longo do cromossomo 1. Setas indicam posições nos cromossomos 1 e 4 . Barra $=10 \mu \mathrm{m}$ (a)(b) e $5 \mu \mathrm{m}$ 


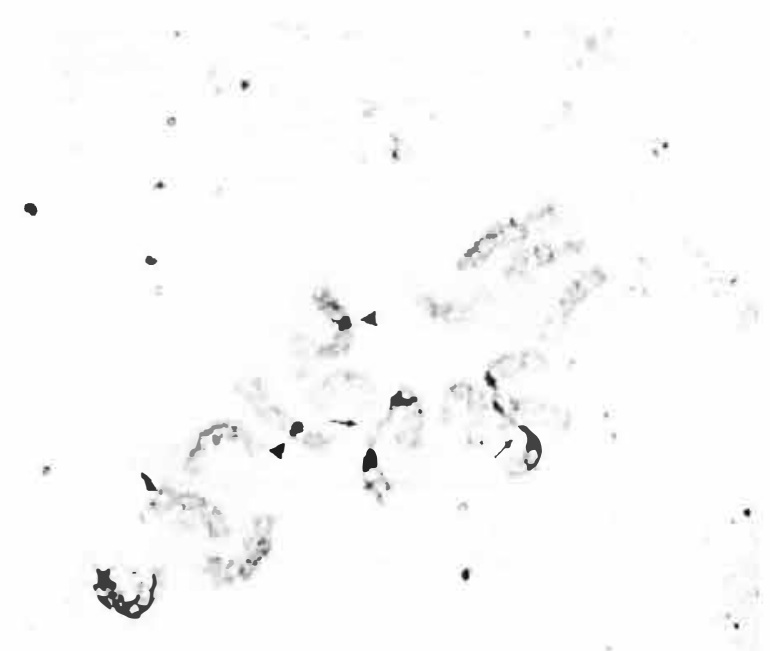

a

,
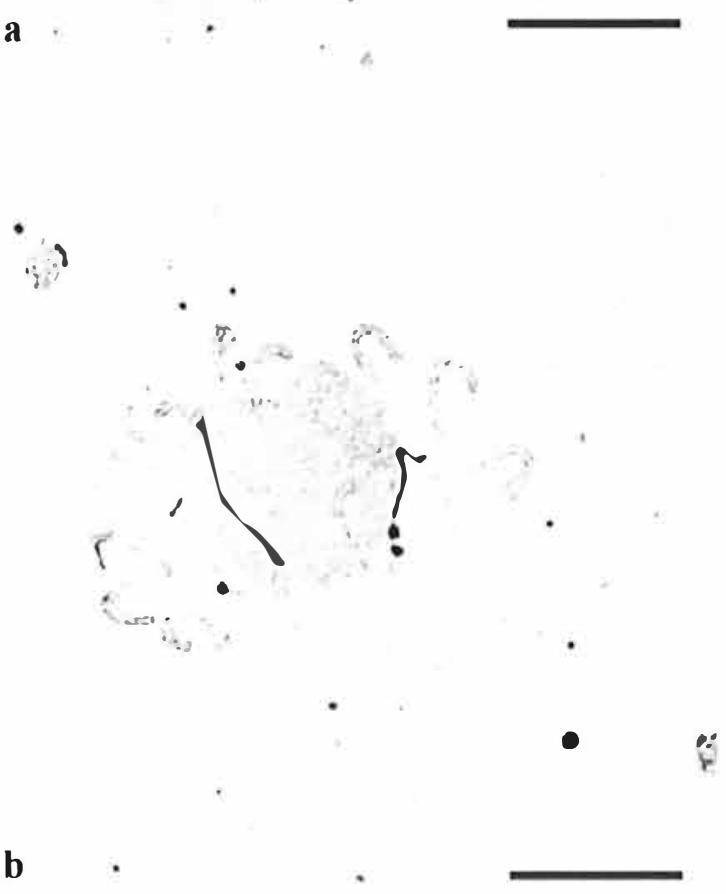

Figura 4 - Bandamento-Ag RON em C. juncea. (a) Metáfase mitótica mostrando marcação na constrição secundária do cromossomo 1 (setas) e no cromossomo 4 no sítio adicional de rDNA 45S. (b) Prófase mitótica onde se observa claramente a constrição secundária associada ao nucléolo, neste caso não há marcação no par 4 . Barra $=10 \mu \mathrm{m}$ 


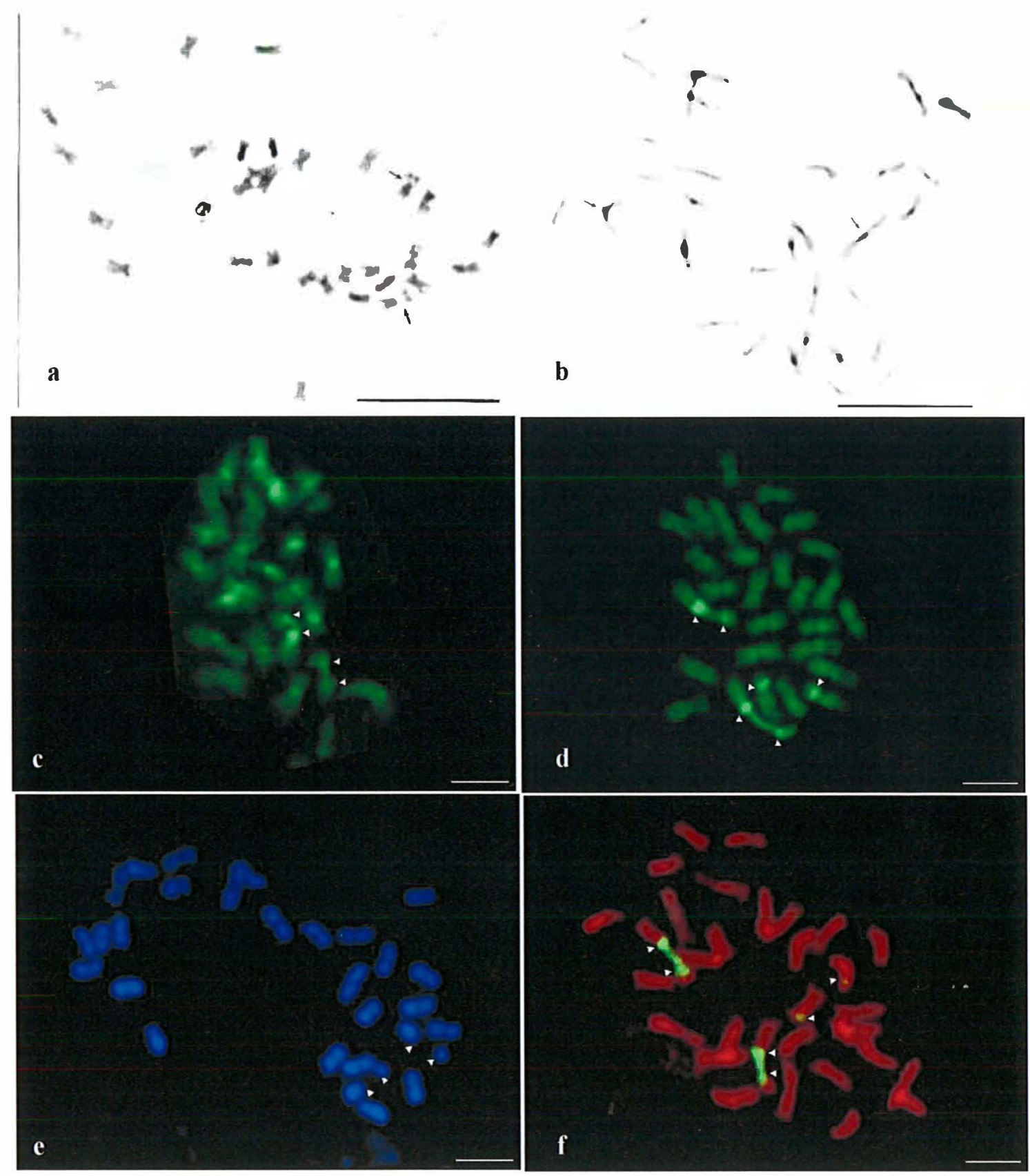

Figura 5 - Crotalaria stipularia - seção Calycinae - $2 n=32$. (a) Metáfase corada pelo método de Feulgen. (b) Bandamento-C mostrando um padrão pericentromérico de marcação. (c) Coloração CMA, mostrando padrão de bandas semelhante aode bandas-C. (d) Coloração CMA/DA. (e) Coloração DAPI/AMD, as regiões heterocromáticas aparecem negativas. (f) FISH com a sonda de rDNA 45S, sítios de hibridação da sonda são observados no cromossomo 1 que possui a região organizadora do nucléolo e em um segundo par de cromossomos observa-se um sítio menor. Setas indicam posições nos cromossomos 1 e homeólogo 4' Barra=10 $\mu \mathrm{m}$ (a)(b) e $5 \mu \mathrm{m}$ 


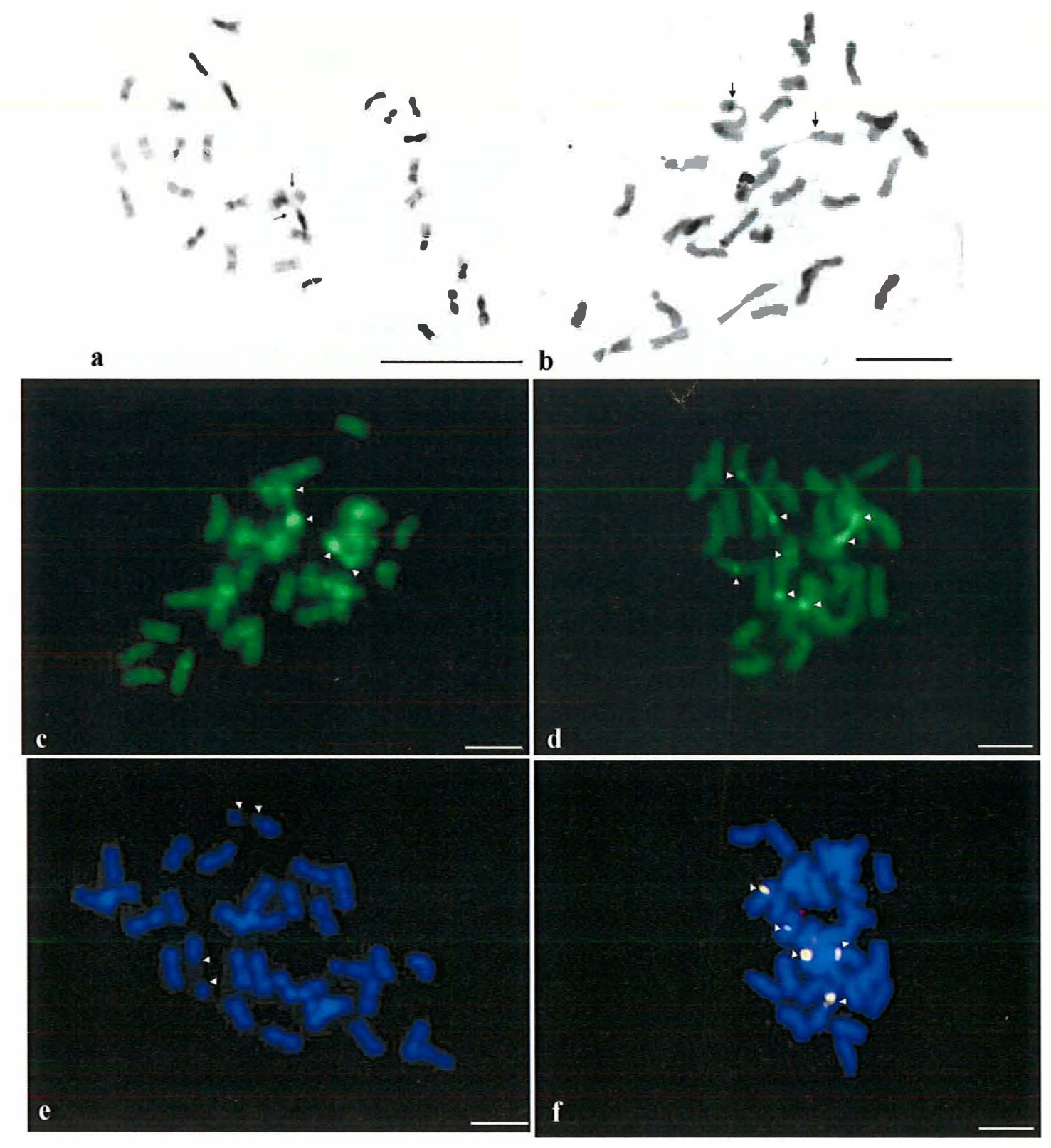

Figura 6 - Crotalaria paulina - seção Calycinae $-2 n=32$. (a) Metáfase corada pelo método de Feulgen. (b) Metáfase corada pelo método do bandamento-C. (C) Metáfase corada apenas com CMA. Todas as regiões pericentroméricas aparecem fluorescentes. (d) Coloração CMA/DA. Apenas três pares de cromossomos são visualizados com bandas fluorescente. (e) Coloração DAPI/AMD. Todos as regiões heterocromáticas pericentroméricas aparecem com fluorescência negativa. (f) FISH com a sonda de rDNA de 45S. Sítios de hibridação são observados no cromossomo 1, correspondentes à região organizadora do nucléolo, um segundo par de cromossomos marcados e o homeólogo 4 'com um sítio menor. Setas indicam as posições nos cromossomos 1 e homeólogos 1' e 4'. Barra=10 $\mu \mathrm{m}$ (a)(b) e $5 \mu \mathrm{m}$ 


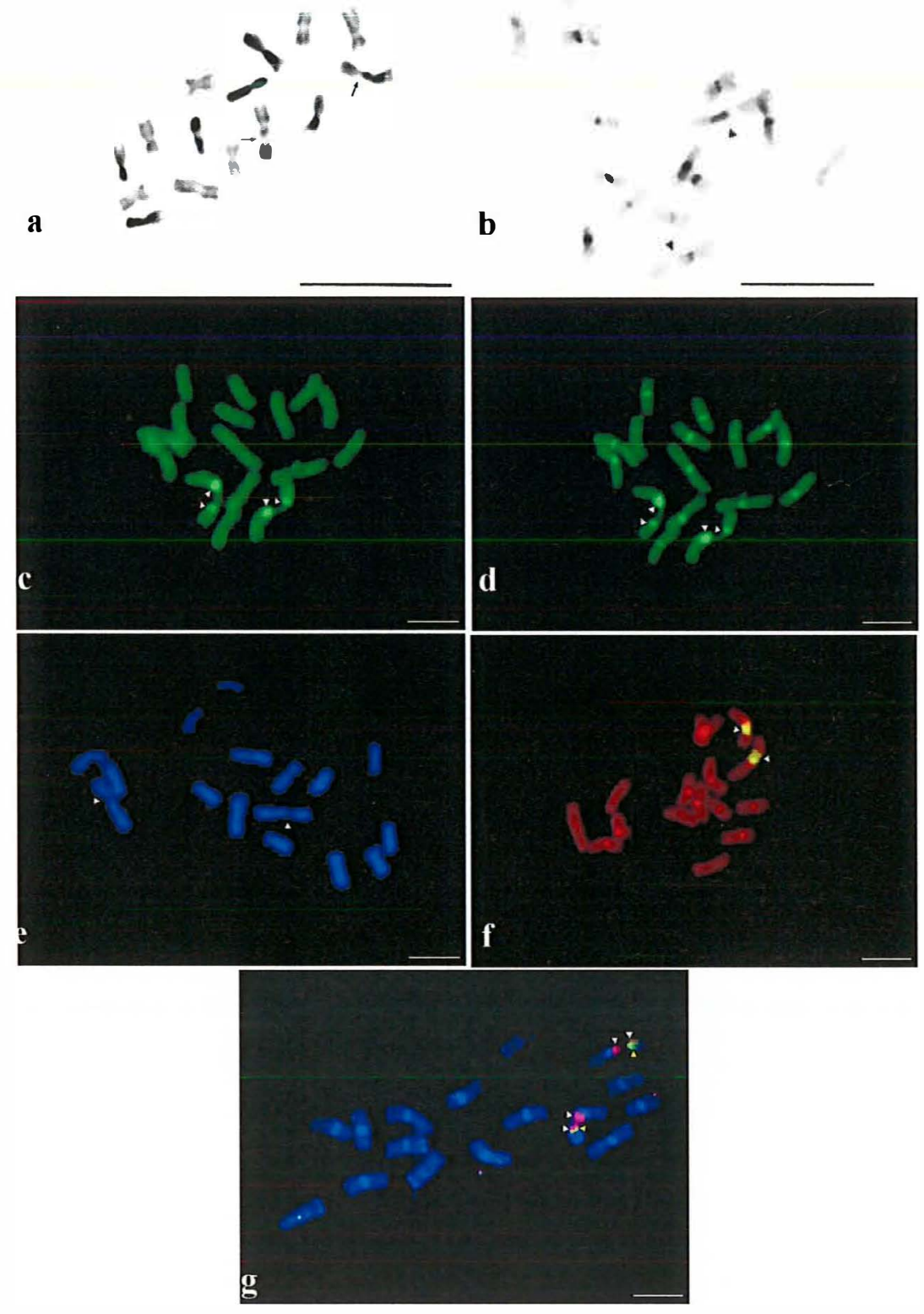

Figura 7 - Crotalaria spectabilis - seção Crotalaria $-2 n=16$. (a) Metáfase corada pelo método de Feulgen. (b) Bandamento-C mostrando heterocromatina na região pericentroméricas. (c) CMA/DA mostrando apenas as heterocromatinas adjacentes à constrição secundária fluorescentes. (d) CMA onde todas as heterocromatinas aparecem fluorescentes, semelhante aos apresentados em b. (c) e (d) foram coradas sequencialmente. (e) Coloração DAPI/AMD, sem a presença de sítios fluorescentes. (f) FISH com a sonda de rDNA de $45 \mathrm{~S}$ mostrando sítios de hibridação apenas no cromossomo 1 correspondente à região organizadora do nucléolo. (g) FISH com sondas de rDNA de 45S (vermelho) e 5S (verde), observa-se um único sítio de $5 \mathrm{~S}$ no braço longo do cromossomo 1; as heterocromatinas fluorescentes são resultado da desnaturação e renaturação do DNA durante a hibridação e não refletem a natureza de suas seqüências. Setas indicam posições no cromossomo 1 . Barra $=10 \mu \mathrm{m}(\mathrm{a})(\mathrm{b}) \mathrm{e}$ $5 \mu \mathrm{m}$ 


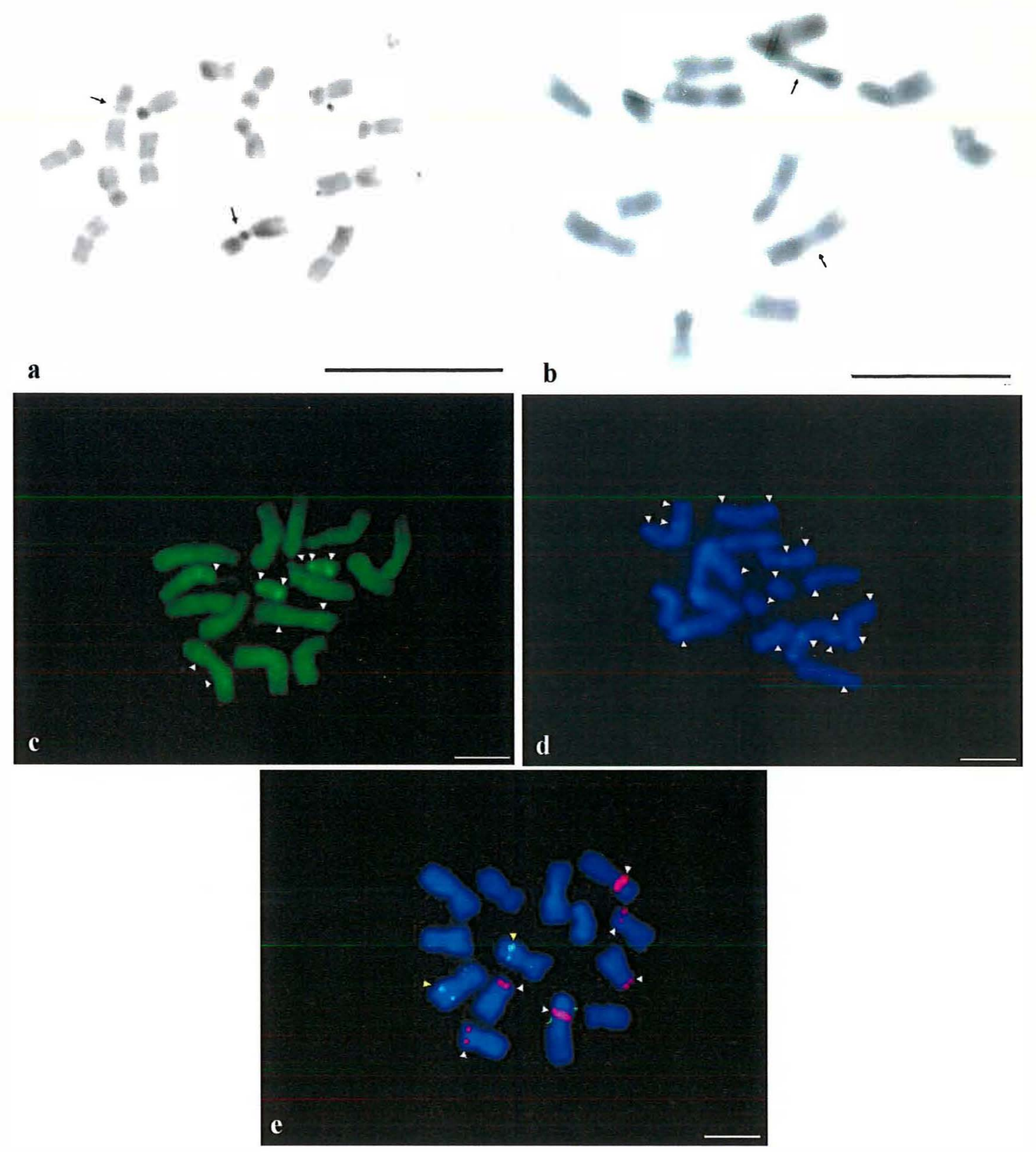

Figura 8 - Crotalaria incana - seção Incanae $-2 n=14$. (a) Metáfase corada pelo método de Feulgen. (b) Bandamento- $C$ onde não se evidencia nenhuma banda, nem mesmo adjacentes a constrição secundária. (c) Metáfase mitótica corada com CMA. Observa-se a heterocromatina associada à região organizadora do nucléolo e um sinal fluorescente na ponta do braço curto. (d) Coloração DAPI/AMD, setas indicam as posições dos sítios fluorescentes. (e) FISH com sondas de rDNA de 45S (vermelho) e 5S (verde), observa-se sítios de rDNA de 45S nos cromossomos 1, 4 e 5, e de $5 \mathrm{~S}$ apenas no cromossomo 3. Setas indicam posições nos cromossomos. Barra $=10 \mu \mathrm{m}(\mathrm{a})(\mathrm{b})$ e $5 \mu \mathrm{m}$ 
$\mathbf{a}$

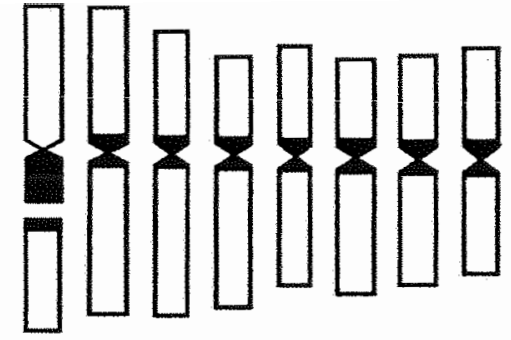

b

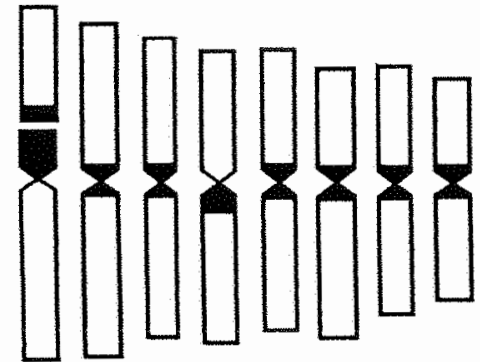

c

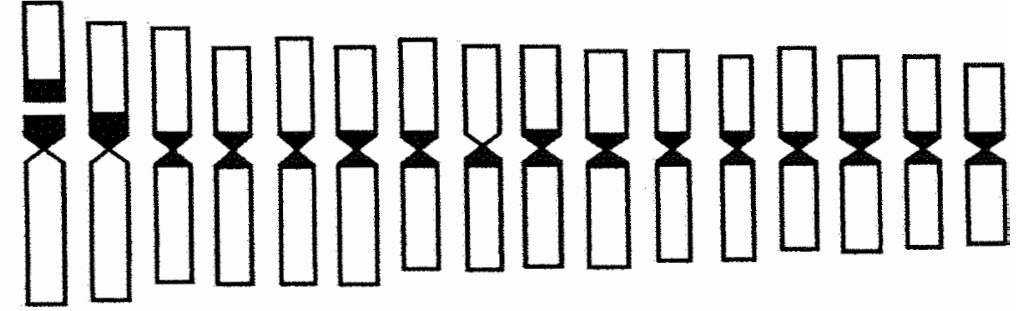

d

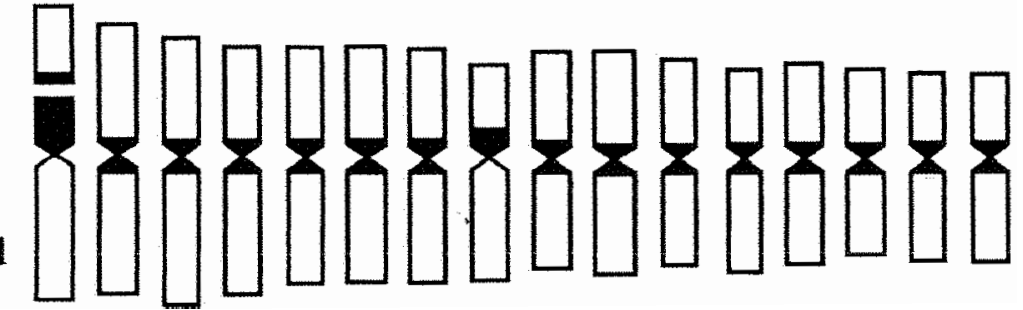

Figura 9 - Idiogramas dos cariótipos com o padrão de bandas-C de espécies de Crotalaria. (a) $C$. spectabilis. (b) C. juncea. (c) C. paulina. (d) C. stipularia. 


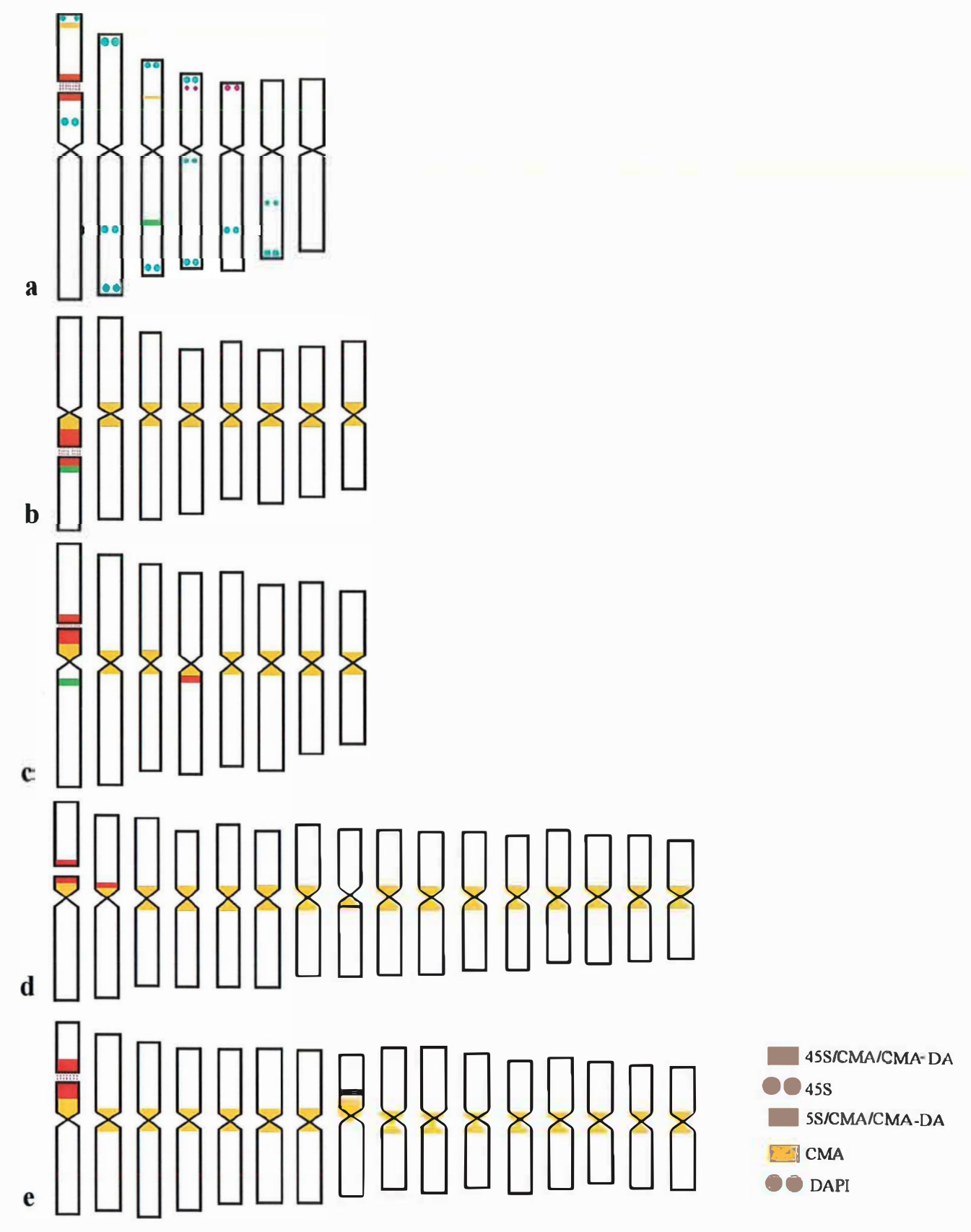

Figura 10 - Mapas físicos dos cromossomos de espécies de Crotalaria. (a) C. incana. (b) C. spectabilis. (c) C. juncea. (d) C. paulina. (e) C. stipularia. 


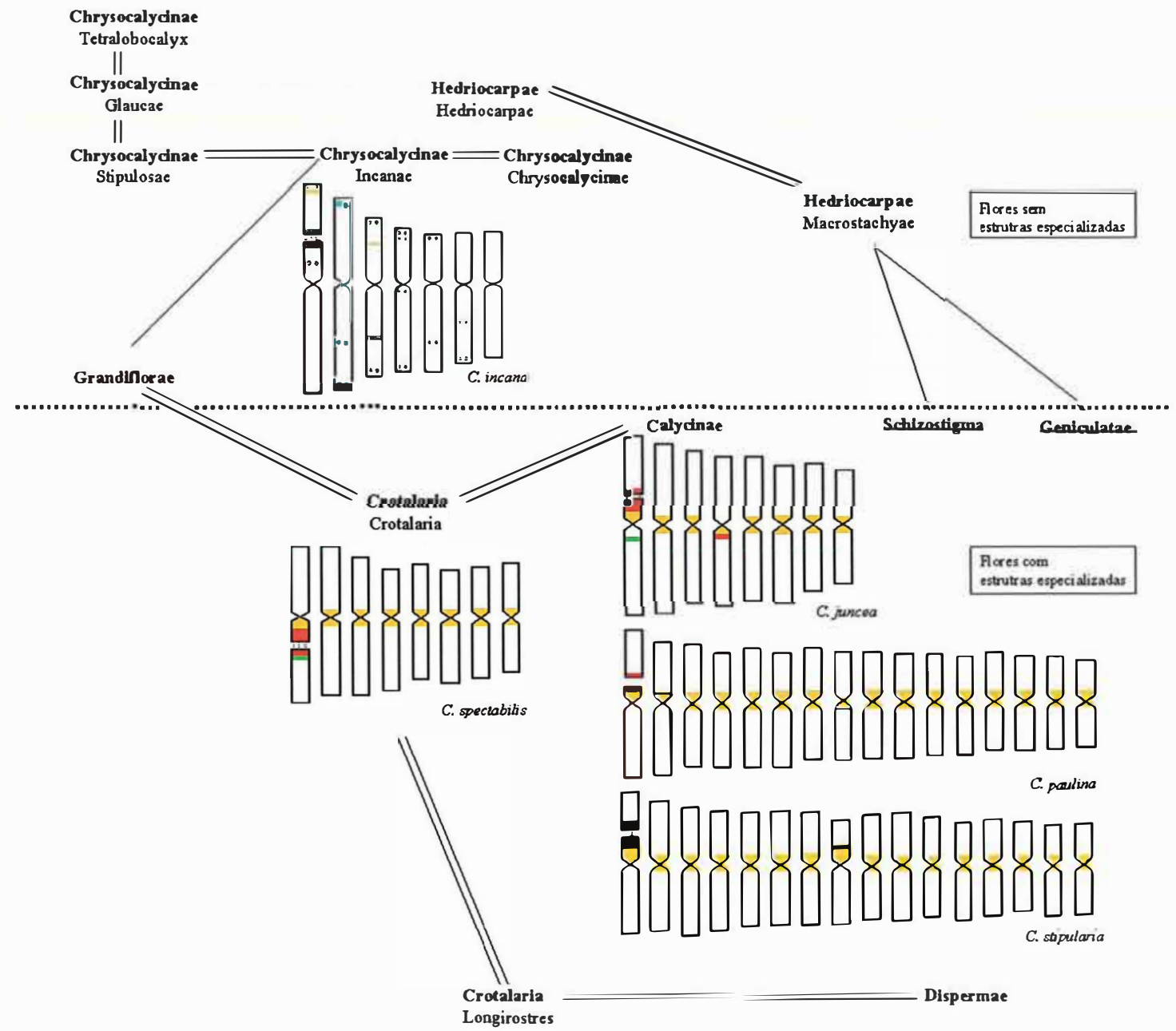

Figura 11 - Modelo integrado entre as relações filogenéticas de seções do gênero Crotalaria e a estrutura dos cariótipos (adaptado de Polhill, 1982). 


\section{DISCUSSÃO}

\subsection{Estrutura dos cromossomos}

Os estudos sobre o cariótipo de espécies de Crotalaria têm descrito a maioria das espécies com $2 \mathrm{n}=16$ cromossomos (Apêndice 1), com apenas uma constrição secundária, localizada no braço curto do cromossomo 1 (Raina \& Verma, 1979; Mangotra \& Koul, 1991; Oliveira \& Aguiar-Perecin, 1999), exceto para C. spectabilis, que apresenta constrição secundária no braço longo (Oliveira \& Aguiar-Perecin, 1999). Os cariótipos são em sua grande maioria do tipo simétrico com cromossomos metacêntricos e submetacêntricos (Oliveira \& Aguiar-Perecin, 1999). Os tamanhos dos cromossomos são relativamente semelhantes o que dificulta a identificação, de modo que outros marcadores ao longo dos cromossomos são úteis em tal tarefa, entretanto medidas de cromossomos em metáfases mitóticas com morfologia nítida, são essenciais para a elaboração de um cariótipo padrão, que descreva a morfologia dos cromossomos, tal como foi obtido por Oliveira \& Aguiar-Perecin (1999) para uma série de espécies de Crotalaria.

Em milho o bandamento-C é uma ferramenta muito importante para identificação de cromossomos mitóticos (Aguiar-Perecin, 1985; Aguiar-Perecin \& Vosa, 1985; Bertão \& Aguiar-Perecin, 2002). Também na família Triticeae, o bandamento-C é fundamental para identificação correta dos cromossomos (Friebe \& Gill, 1997). Entretanto, em $C$. juncea, C. stipularia, C. paulina e C. spectabilis o padrão pericentromérico das bandas$\mathrm{C}$ não permite uma identificação rápida dos cromossomos. Este padrão pericentromérico de bandas-C tem sido observado em outros gêneros e espécies da família Leguminosae, como é o caso de Vigna (Galasso et al., 1992; Galasso et al., 1993), Vicia atropurpurea 
(Cremonini et al., 1993), Cicer (Tayyar et al., 1994), Lathyrus (Ünal et al., 1995) e Medicago sativa ssp. falcata (Bauchan \& Hossain 1999).

Cromossomos com constrição secundária freqüentemente apresentam blocos heterocromáticos detectáveis pelo bandamento-C, adjacentes a estas regiões menos condensadas. Nas espécies de Crotalaria pertencentes à seção Calycinae e Crotalaria o cromossomo 1, com a contrição secundária, apresenta dois blocos heterocromáticos adjacentes à constrição secundária, um proximal e outro distal. Este mesmo padrão de heterocromatinas adjacentes à região organizadora do nucléolo foi observado em Vigna unguiculata (Galasso et al., 1992), Vicia atropurpurea (Cremonini et al., 1993) e Vicia faba (Fuchs et al., 1998b) e também em espécies de outras famílias de plantas como em Cephalanthera (Ochidaceae) (Schwarzacher \& Schweizer, 1982) e Gibasis karwinskyana (Commelinaceae) (Kenton, 1991). Entretanto, este padrão de heterocromatinas detectadas por bandamento-C não foi observado em $C$. incana. É possível que pelo seu pequeno tamanho ou estado de condensação não tenha sido detectado pela técnica empregada.

As seqüências que compõem as regiões heterocromáticas pericentroméricas e as associadas à RON nas espécies da seção Calycinae e Crotalaria são ricas em GC, uma vez que ambas quando coradas com CMA apresentam fluorescência intensa. Em $C$. incana somente a constrição secundária e três sítios menores apresentam fluorescência com CMA. A composição do DNA cromossômico é o determinante primário para o bandamento fluorescente (Schweizer, 1976a; Schweizer, 1983). As heterocromatinas associadas à região organizadora do nucléolo são descritas como sítios CMA fluorescentes em um grande número de espécies (Schweizer, 1976a; Schweizer, 1977; Schwarzacher \& Schweizer, 1982; Kenton, 1991; Galasso et al., 1993; Doudrick et al., 1995; Fuchs et al., 1998b; Forni-Martins \& Guerra, 1999).

Além disso, no caso das espécies de Crotalaria estas regiões heterocromáticas associadas à RON podem, ainda, ser diferenciadas pela combinação de CMA com DA. Neste caso, as heterocromatinas pericentroméricas perdem sua fluorescência permanecendo fluorescente apenas aquelas ligadas à RON, ou outras regiões que contenham as seqüências para os genes ribossomais, ou ainda regiões na cromatina em 
sítios que não correspondem a bandas- $\mathrm{C}$, como o sítio fluorescente no braço longo do cromossomo 1 de $C$. juncea, ou os sítios fluorescentes no braço curto do cromossomo 1 e os intersticiais dos braços curto e longo do cromossomo 3 de $C$. incana. Schweizer (1976a) descreve que em Vicia faba a combinação de CMA e metil-green, não alterava qualitativamente o padrão de bandas, mas aumentava o contraste do brilho da banda na constrição secundária. Entretanto, no nosso caso a combinação de fluorocromos permitiu uma alteração quantitativa no padrão de bandas, para as espécies das seções Calycinae e Crotalaria, diferenciando bandas pericentroméricas e associadas à RON. Schwarzacher \& Schweizer (1982) estudando o gênero Cephalanthera obtiveram marcações fluorescentes específicas para alguns cromossomos, quando utilizaram combinações CMA/DA, DAPI/AMD e quinacrina/AMD, embora todos os cromossomos tivessem bandas-C. A seleção de bandas cromossomo específicas também são relatadas em humanos. A combinação DAPI/DA permite identificar bandas fluorescentes específicas nos cromossomos 1, 9, 15, 16 e Y (Schweizer et al., 1978; Schweizer, 1983). Em geral bandas fluorescentes positivas e negativas em plantas, correspondem as bandas-C, entretanto, nem toda banda-C pode ser detectada por técnicas de bandamento fluorescente (Friebe et al., 1996).

A coloração com DAPI e DAPI/AMD não revelou bandas fluorescentes em espécies das seções Calycinae e Crotalaria, mas evidenciou regiões com fluorescência reduzida. Esta informação reforça a observação de que realmente estas regiões sejam muito ricas em GC. A utilização do contra-corante $\mathrm{AMD}$, que é específico para regiões ricas em GC, provavelmente se liga a estas regiões, no caso de $C$. juncea, C. stipularia, C. paulina e $C$. spectabilis a região pericentromérica e adjacentes à constrição secundária, impedindo a fluorescência do DAPI. Isto ocorre pois o DAPI tem emissão de energia no mesmo comprimento de onda de absorção do $\mathrm{AMD}$, de forma que este ultimo rouba a energia do DAPI, em um processo denominado energia de transferência, impedindo a fluorescência do DAPI (Schweizer, 1981). O mecanismo envolvido na diferenciação de bandas ricas em GC, difere completamente do que foi apresentado para DAPI/AMD. Neste caso o CMA se liga em todos os resíduos GC, permitindo sua fluorescêcia intensa nas regiões pericentroméricas e nas adjacentes à RON, entretanto, 
quando a DA é aplicada esta tende a se ligar nos resíduos AT das seqüências de DNA, de modo que devido ao tipo de arranjo dos nucleotídeos a DA retira o CMA impedindo sua fluorescência por competição pelo sítios, assim somente regiões com muito resíduos de GC e pouco AT permanecem fluorescente. Schweizer (1981) detalha este mecanismo de competição em combinação de fluorocromos primários e contra-corantes, para cromossomos humanos, onde a combinação DAPI/DA revela regiões fluorescentes em cromossomos específicos, como descrito anteriormente, sendo que neste caso o DA se liga ao longo dos cromossomos e em arranjos específicos dos nucleotídeos AT, permitindo um maior contraste das regiões onde o DAPI está ligado (Schweizer, 1983).

Diferentemente das demais espécies, $C$. incana apresenta sinais fluorescentes para colorações com DAPI e DAPI/AMD, entretanto neste caso não é observado uma diferenciação no padrão de fluorescência. Da mesma forma, as colorações com CMA e CMA/DA não diferenciaram padrões específicos de sinais fluorescentes. Provavelmente esta não observação de diferenciação de sinais fluorescentes em $C$. incana, seja o resultado de diversidade das seqüências repetitivas que compõem estas regiões e $C$. incana neste caso possui regiões de DNA espécie-específico, tal como foi observado por Galasso et al. (1995) para Vigna unguiculata.

Em todas as espécies, as bandas fluorescentes diferenciadas por CMA/DA, correspondem a sítios dos genes ribossomais de $45 \mathrm{~S}$, exceto os sítios de rDNA de $45 \mathrm{~S}$ localizados nos braços curtos dos cromossomos 4 e 5 de $C$. incana. Esta correlação já era esperada, de acordo com o exposto acima. Outros trabalhos, também relacionam sítios de CMA com regiões que apresentam hibridação da sonda de rDNA de $45 \mathrm{~S}$ (Doudrick et al., 1995; Galasso et al., 1995; Cerbah et al., 1995; Fuchs et al., 1998b; Cerbah et al., 1998; Galasso et al., 1998; Roose et al., 1998; Siljak-Yakovlev et al., 2003). Entretanto, Doudrick et al. (1995) relata que nem todas as bandas CMA fluorescentes correspondiam aos sítios de hibridação da sonda de rDNA de 45S. Esta não correlação também pode ser percebida sem a utilização de hibridação in situ. Já em Vigna unguiculata em todas as linhagens analisadas, foi possível uma estrita correspondência entre os sítios de hibridação da sonda de rDNA de $45 \mathrm{~S}$ e as heterocromatinas fluorescentes com CMA (Galasso et al., 1998). No caso de $C$. incana 
onde dois sítiosde rDNA 45S nos cromossomos 4 e 5 não apresentaram esta correspondência, a explicação pode residir no fato destes sítios serem extremamente pequenos e desta forma a coloração com o fluorocromo CMA ou CMADDA não foi sensível para detecção, mas certamente estes sítios são ricos em GC, como é da estrutura do rDNA de $45 \mathrm{~S}$ de plantas.

As espécies $C$. juncea, $C$. incana e $C$. spectabilis ainda apresentaram correspondência entre o sítio de hibridação do rDNA de $5 \mathrm{~S}$ e sítios fluorescentes diferenciados com CMA/DA. Esta correspondência é mais clara nas espécies $C$. juncea $\mathrm{e}$ C. incana que possuem o loco de rDNA de $5 \mathrm{~S}$ distante do de $45 \mathrm{~S}$ ou está localizado em outro cromossomo. No caso de $C$. spectabilis devido à proximidade entre os locos de rDNA de $45 \mathrm{~S}$ e $5 \mathrm{~S}$, não é fácil a diferenciação deste ultimo. A correspondência entre sítios de rDNA de $5 \mathrm{~S}$ e sinais fluorescentes com CMA não são comuns na literatura. Esta correspondência foi observada em espécies dos gênero Hypochaeris (Cerbah et al., 1998) e Lilium (Siljak-Yakovlev et al., 2003).

Regiões de DNA ribossômico adicionais em espécies de plantas podem ter origem em eventos de poliploidia, onde o complemento cromossômico é duplicado como um todo, como no caso das espécies poliplóides $C$. stipularia e C. paulina da seção Calycinae. Entretanto, esta oḅservação não é capaz de explicar a origem de sítios adicionais de rDNA de $45 \mathrm{~S}$ em plantas estritamente diplóides, como é o caso de $C$. juncea e $C$. incana. Existem evidencias de que o rDNA de $45 \mathrm{~S}$ apresente características de elemento transponível. Entretanto na estrutura molecular do rDNA $45 \mathrm{~S}$ de trigo descrita por Flavell (1989) não há nenhuma evidência de arranjos de seqüências, como terminais invertidos que é uma característica muito comum dos elementos de transposição, que lhe confiram esta característica. Schubert \& Wobus (1985), estudando algumas linhagens de cebola denomindas "Top-onion", puderam observar que após determinados cruzamentos, novos sítios de rDNA 45S surgiram em posições em que anteriormente não eram observados. Ainda no gênero Allium, Schubert (1984) e Schubert \& Wobus (1985) mostraram que existem mais evidências citológicas de que estas regiões de DNA ribossômico têm mudado de posição, observações estas feitas através do surgimento de novas RONs ativas coradas por nitrato de prata e pelo 
aparecimento de blocos heterocromáticos adjacentes à estas novas RONs. Além disso, esta possibilidade de transposição já é utilizada para explicar a quebra de sintenia destes locos de rDNA 45S com os grupos de ligação no gênero Oryza (Shishido et al., 2000) e em espécies da tribo Triticeae (Dubcovsky \& Dvorak, 1995). A melhor evidência de que o rDNA de $45 \mathrm{~S}$ tenha esta capacidade, está nas observações da espécie Hypochaeris radicata, onde a ocorrência de quebra de um dos cromossomos 1 por fissão cêntrica é acompanhada por ganhos de seqüências de rDNA, confirmadas por hibridação in situ e presença de constrições secundárias com atividade nucleolar nas extremidades dos telocêntricos formados e em posição intersticial do cromossomo 1 padrão, que originalmente não continha este tipo de seqüência, sendo que nas espécies onde esta quebra não ocorre, há um único lóco de rDNA de 45S localizado no cromossomo 3 na extremidade de um dos braços (Hall \& Parker, 1995). Esta talvez seja a melhor explicação para o surgimento de sítios adicionais no braço longo do cromossomo 4 de $C$. juncea e nas posições subterminal do cromossomo 4 e terminal do cromossomo 5 de $C$. incana, de forma que o sítio original localizado no cromossomo 1, padrão para o gênero, por razões de estresse se mova para outras regiões dos cromossomos. A grande dificuldade de aceitação desta hipótese reside no fato de ainda não existir evidências moleculares da capacidade do DNA ribossômico se transpor ou mesmo se quer um modelo para que isso ocorre, mesmo que teórico.

Embora o completo cromossômico possa ter mais de um sítio de genes ribossomais de $45 \mathrm{~S}$, nem sempre todos estes lócus são ativos. Formi-Martins \& Guerra (1999) observaram que em Sesbania raramente o número de bandas CMA fluorescentes coincide com o número de constrições secundárias descritas. Estes descrevem que, o número de constrições secundárias depende da atividade nucleolar na interfase anterior e pode ser subestimada, mas que o número de bandas CMA fluorescentes não. Em Vigna unguiculata, em que foram detectados 5 sítios de genes ribossomais de $45 \mathrm{~S}$, sendo quatro maiores e um menor, somente este último sítio não apresentou atividade transcricional (Galasso et al., 1998). Em C. juncea a coloração com nitrato de prata às vezes apresenta marcação no loco de genes ribossomais de $45 \mathrm{~S}$ do cromossomo 4, entretanto em muitos casos não é observado qualquer tipo de marcação. Em muitas 
prófases, quando o nucléolo é ainda visível, observa-se claramente o cromossomo 1 associado a esta organela, mas nunca o cromossomo 4.

Galasso et al. (1995) havia descrito que o sítio menor de Vigna unguiculata não era expresso em núcleos de células de ponta de raízes, mas que, entretanto em cevada, evidências de associações de cromossomos meióticos com nucléolos indicava que à atividade de sítios menores podiam ser detectados nesta fase do desenvolvimento da planta (Tschiya 1960 citado por Galasso et al., 1995). Estas observações não descartam a possibilidade deste sítio adicional de $C$. juncea ser parcialmente ativo na raiz e ter uma atividade mais expressiva em outras fases do desenvolvimento da planta, mas estudos detalhados a este respeito devem ser conduzidos. Observações de sítios menores ativos também foram descritas para Trigonella foenum-graecum (Leguminosae), entretanto nesta espécie os sítios menores formam constrição secundária (Ahmad et al., 1999), o que não é observado em $C$. juncea. Uma possibilidade é a de que a quantidade de regiões codantes expressas no sítio adicional de rDNA de $45 \mathrm{~S}$ em $C$. juncea seja tão pequeno que não haja a formação de constrição secundária.

Certamente, os métodos de bandamento-C, coloração com fluorocromos e FISH de rDNAs são capazes de detectar tipos específicos de arranjos cromossômicos, tal como foi observado para $C$. juncea e $C$. spectabilis que apresentam uma inversão pericêntrica, dificeis de serem identificados, utilizando-se outros métodos. Os locos de rDNA de 45S podem ser marcadores úteis para uma conexão entre o cromossomo e o mapa de ligação e para seguir determinados cromossomos em programas de hibridações e cruzamentos interespecíficos (Galasso et al., 1995). Estes marcadores foram capazes de descrever com precisão os cromossomos de espécies de Crotalaria, sendo que em alguns casos foi possível até uma subdivisão de estruturas dentro de um mesmo cromossomo, tornando possível sua identificação precisa, representando ótimos marcadores cromossômicos para estudo da evolução de cariótipos. 


\subsection{Evolução dos cariótipos e sua concordância com a taximetria do gênero Crotalaria}

O gênero Crotalaria com mais de 550 espécies descritas foi de modo muito interessante organizado em seções e subseções botânicas, para agrupar espécies com características morfológicas semelhantes. Isto foi primeiramente proposto por Polbill (1968) utilizando-se de uma metodologia ortodoxa de divisão, ou seja, sem uma análise estatística, mas sim baseado no seu conhecimento de campo e de herbário (Bisby, 1973). Esta primeira classificação em seções e subseções foi alterada a partir de uma série de análises taximétricas realizadas por Bisby (1970), Bisby (1973) e Bisby \& Polhill (1973).

Estas subdivisões não foram de elaboração simples (Bisby, 1973), uma vez que o grupo apresenta uma evolução extremamente reticulada, onde conjuntos de características especializadas misturam-se a não especializadas, ou até mesmo desaparecem em um grupo primitivo e reaparecem em um grupo mais evoluído (Bisby, 1973; Bisby \& Polhill, 1973). Mesmo assim a maioria das espécies se acomoda bem dentro dos grupos estabelecidos.

A citogenética pode levar a importantes estudos de relações filogenéticas e que dão suporte à classificação taxonộmica realizada através da análise de caracteres morfológicos da planta, bem como de características moleculares dos cromossomos que permitem estudos sobre a evolução dos cariótipos das espécies.

Os resultados de Boulter et al. (1970) são grande prova disso. As espécies de Crotalaria apresentavam características de número e de tamanho dos cromossomos, que concordava com a subdivisão do gênero. Além disso, o trabalho de Boulter et al. (1970) indicava que havia uma redução do tamanho dos cromossomos com a especialização floral das espécies.

Oliveira \& Aguiar-Perecin (1999) também mostraram em um estudo mais detalhado sobre a evolução dos cariótipos deste gênero, que cada seção apresentava características marcantes de simetria e tamanho dos cromossomos, sendo que a seção mais especializada apresentava maior assimetria e menor tamanho dos cromossomos. Fica claro que dentro do gênero existe uma tendência de evolução dos cariótipos 
(Oliveira \& Aguiar-Perecin, 1999), mas que para esta tendência ser vista é necessário uma visão geral das espécies até agora conhecidas do ponto de vista citogenético.

Por estas razões outros trabalhos de citogenética não conseguiram fazer considerações interessantes sobre a evolução cariotípica do gênero. Por exemplo, os trabalhos de Gupta \& Gupta (1978a), Gupta \& Gupta (1978b), Raina \& Verma (1979) e Verma et al. (1984). Embora, estes trabalhos apresentem ótimas descrições cariotípicas, a falta de uma subdivisão das espécies limita a interpretação dos autores. O mesmo ocorre com Gupta (1976) que apesar de dividir as espécies em seções, não a utiliza para fazer considerações sobre a evolução do grupo.

A combinação de métodos citogenéticos que permitem a obtenção de marcadores citológicos e os dados botânicos representam uma ferramenta poderosa para estudo da evolução de cariótipos.

Embora o nosso número de espécies estudadas seja restrito, as observações sobre as estruturas dos cromossomos e seus polimorfismos permitiram concordar com as subdivisões botânicas, o que de certa forma era esperado, pois as análises de cariótipos e do complemento cromossômico já indicavam esta concondância (Boulter et al., 1970; Oliveira \& Aguiar-Perecin, 1999).

As espécies podem ser divididas claramente em três grupos. A seção Calycinae é marcada pela presença de um sítio adional de rDNA de $45 \mathrm{~S}$ no braço longo do cromossomo 4, o que a difere da $C$. spectabilis representante da seção Crotalaria subseção Crotalaria, além disso as espécies poliplóides concentram-se na primeira seção. As duas seções ainda compartilham de semelhanças quanto à posição das bandas-C e à sua natureza rica em GC. Estas ultimas características tornam estas subseções filogeneticamente relacionadas, o que está em concordância com o seus graus de especialização floral (Bisby \& Polhill, 1973; Polhill, 1982).

A espécie $C$. incana, pertence a um grupo completamente distinto de espécies, tal que, Bisby \& Polhill (1973) criaram uma subseção dentro da seção Chrysocalycinae para agrupar as espécies relacionas a $C$. incana. As espécies desta subseção apresentam um número cromossômico de 2 n=14 (veja revisão do número de cromossomos dividido por seções e subseções no apêndice 1), embora ocorram espécies com $2 n=16$. Este 
grupo, além disso, não apresenta flores com estruturas especializadas, tem origem em uma região muito restrita ao sul da África e com posterior dispersão para outras regiões (Polhill, 1982).

A análise dos cromossomos de $C$. incana mostra que ela é distante das espécies de outras seções investigadas. Não há ocorrência de bandas-C nas regiões pericentroméricas, não há ocorrência de grande blocos de heterocromatina ricas em GC, o número de locos de rDNA de $45 \mathrm{~S}$ é maior do que as demais espécies e juntamente com o rDNA de 5S não apresentam sintenia destes mesmos marcadores nas outras espécies.

A espécie $C$. incana é considerada uma das espécies mais antigas do gênero (Polhill, 1982) e deste modo esta espécie teve mais tempo para se derivar. Muitos trabalhos de citogenética por não levar em consideração esta condição para $C$. incana, interpretam erroneamente esta espécie como uma das mais evoluídas devido ao seu cariótipo assimétrico, como proposto por Chennaveeraiah \& Patil (1973) e Patil \& Chennaveeraiah (1975).

Stebbins (1971) relata que cariótipos assimétricos na maioria das vezes estão associados com a redução do número de cromossomos, mas também estão associados com inversões pericêntricas e translocações desiguais que fixam grupos de ligação de genes importantes para adaptação dos organismos a novos habitats. E esta consideração está de acordo com as observações feitas para $C$. incana. Após sua dispersão a partir do sul da África, ela é encontrada praticamente em todo o mundo, sendo que para cada região são descritos novos cariótipos, tornando esta espécie muito polimorfica, com muitos citotipos descritos (Palomino e Vázquez, 1991).

Embora, os nossos dados não permitam uma exploração mais profunda sobre esta espécie, dois resultados devem ser considerados: o primeiro de que agora existem marcadores específicos para cada cromossomo desta espécie, permitindo uma comparação entre acessos; e segundo, claramente esta espécie difere das demais estudadas neste trabalho.

A espécie $C$. incana é a única espécie neste trabalho, relacionada com o centro primário de origem na África. Tanto C. juncea, como C. spectabilis apresentam os respectivos centros de origem fora da África, mais exatamente na Índia de onde há um 
fluxo de migração para o continente americano onde surgem as espécies poliplóides da seção Calycinae, embora seja controverso se $C$. sptipularia tenha origem na Índia ou não (Polhill, 1982). A maioria das espécies poliplóides ocorrem na América (Windler, 1974), tanto que Lewis (1987) sugere que C. stipularia seja descrita como tendo dois tipos descritos um da Índia e um da América.

Estas observações geográficas sugerem que estas espécies com flores mais especializadas tenham uma origem mais recente em relação a $C$. incana (Polhill, 1982). Deste modo os nossos dados indicam um acúmulo de seqüências de DNA ricas em GC localizadas em regiões pericentroméricas, além da redução do número de sítios de rDNA de 45S, nas espécies $C$. juncea e $C$. spectabilis em relação ao número apresentado por $C$. incana. A ocorrência de especiação por poliploidia provavelmente ocorre após a migração e com a introdução de espécies da seção Calycinae na América, como dito anteiormente.

Entretanto, resta a questão: como teria surgido o número básico $\mathrm{x}=14$ na subseção Incanae? Os nossos dados não permitem uma conclusão, ou uma interpretação direta do caso, mas permite uma inferência a partir do panorama da evolução das outras espécies acima descrito.

A perda de sintenia do lóco de rDNA de $5 \mathrm{~S}$ passando do cromossomo 1 para o cromossomo 3 e dos locos de rDNA de $45 \mathrm{~S}$ ocorrendo em posições terminais e subterminais dos cromossomos 4 e 5 em $C$. incana em relação as outras espécies, bem como a ocorrência de sítios fluorescentes DAPI em posição intersticiais levam a hipótese de que realmente esta espécie tenha surgido por translocações a partir de espécies com $2 \mathrm{n}=16$ cromossomos da própria seção Chrysocalycinae que levaram a perda de um centrômero e posteriormente a ocorrência de inversões, como já descrito. Esta suposição já havia sido prosposta por Senn (1938) e Atchinson (1950) e os marcadores cromossomos indicam a mesma direção.

Stebbins (1971) descreve detalhadamente este mecanismo de perda de um cromossomo através de translocações e sem perdas drásticas de material genético, pois como apontado por Oliveira \& Aguiar-Perecin (1999) esta espécie apresenta comprimento do lote haplóide muito semelhante aos das demais espécies e os dados de 
medida do conteúdo de DNA indica que esta espécie é a tem a maior quantidade de DNA (Gupta, 1976).

Embora esta derivação do cariótipo não tenha garantido ganhos de especialização floral, tal como observado na maioria das espécies conhecidas (Stebbins, 1971), permitiu a $C$. incana se adaptar a diferentes habitats, desde a África passando pela Eurásia e chegando ao novo mundo.

Assim, os marcadores cromossômicos descritos, obtidos a partir do bandamento-C, coloração com fluororomos e FISH de rDNAs de $45 \mathrm{~S}$ e $5 \mathrm{~S}$ mostram-se importantes para o estudo da evolução dos cromossomos de espécies de Crotalaria. Obviamente que um número maior de espécies deve ser analisado, bem como devem ser empregados outros marcadores de seqüências repetitivas tal como seqüências telôméricas e seqüências repetitivas em tandem isoladas a partir destas espécies. Entretanto, neste estudo os resultados obtidos reforçam as subdivisões botânicas, havendo concordância entre a evolução dos marcadores cromossômicos e os dados sistemáticos e fitogeográficos existentes.

\subsection{Origem e evolução de espécies alopoliplóides}

A grande maioria das espécies poliplóides de Crotalaria, ocorre na seção Calycinae (Apêndice 1), principalmente em espécies do continente americano (Windler, 1974). Isto nos leva a crer que a poliploidia teve papel fundamental na especiação deste gênero no continente. As espécies poliplóides de Crotalaria, sua grande maioria com $2 \mathrm{n}=32$ cromossomos possuem apenas um par de cromossomos com constrição secundária (Mangotra \& Koul, 1991; Cequea \& Nirchio, 1998; Oliveira \& AguiarPerecin, 1999). Além desta observação Oliveira \& Aguiar-Perecin (1999) ainda notaram que o comprimento do lote haplóide destas espécies nunca dobrava em relação às espécies diplóides. Sugeriram que deveria ter ocorrido redução no conteúdo de DNA durante a evolução e que como não havia uma correspondência entre o número de constrições secundárias e o grau de ploidia, provavelmente existiriam outras regiões capazes de organizar nucléolos, mas que devido à anfiplastia ou dominância nucleolar 
estas não eram detectadas na forma de constrições secundária. Estas observações sugeriram que provavelmente estas espécies sejam alopoliplóides (Verma \& Raina, 1983; Cequea \& Nirchio, 1998) e que provavelmente tiveram origem dentro da própria seção Calycinae (Oliveira e Aguiar-Perecin, 1999).

A hibridação da sonda de rDNA de $45 \mathrm{~S}$ revelou que a espécie diplóide $C$. juncea possui dois lócus, um no cromossomo 1 que possui a constrição secundária e outro no braço longo do cromossomo 4. Supondo que este seria um cariótipo semelhante ao dos ancestrais poliplóides, uma vez que o evento ocorreu entre diplóides da seção Calycinae, seria esperado a ocorrência de quatro locos de rDNA de $45 \mathrm{~S}$ nas espécies poliplóides. Entretanto, foi observado que a espécie $C$. paulina possui 3 locos, enquanto C. stipularia possui apenas dois locos.

A morfologia dos cromossomos e o padrão do sinal de hibridação, permitiu observar que nestes poliplóides ocorre tanto perda como silenciamento dos sítios ribossomais. Chen et al., 1998 e Lewis \& Pikaard, 2001 descrevem que no alopoliplóide natural Arabidopsis suecia, que tem como ancestrais Arabidopsis thaliana e Cardaminopsis arenosa, o silenciamento de genes de rRNA invariavelmente ocorrem nos cromossomos de A. thaliana. Maluszynska \& Heslop-Harrison (1993) observaram que em espécies do gênero Arabidopsis há uma variabilidade no número de sítios de rDNA 45S mapeados por FISH, supondo que há perda destes sítios durante a evolução das espécies deste gênero.

No caso de $C$. paulina, onde três sítios são observados, podemos considerar que o cromossomo com sinal maior, porém sem constrição secundária é homeólogo do cromossomo 1 com constrição secundária, logo conclui-se que há uma dominância nucleolar entre estes locos. Porém o outro sítio localizado no cromossomo 8, apresenta relações de homeologia com o cromossomo 4 de $C$. juncea, neste caso o outro par de homeólogo perdeu o sítio de rDNA de 45S.

A espécie $C$. stipularia neste caso, representaria um extremo da perda de seqüências de rDNA, pois o seu número de sítios é igual ao observado em $C$. juncea que é diplóide. De tal modo que não há sítios de rDNA de 45S no cromossomo homeólogo ao cromossomo 1 e nem no cromossomo homeólogo do 4 , sendo que este último ainda 
esta inativo, ou pelo menos parcialmente inativo em relação ao cromossomo 1 que apresenta constrição secundária, tal como foi observado para o cromossomo 4 de $C$. juncea, onde é possível em algumas metáfases observar a coloração por nitrato de prata nesta região e a observação de micronucléolos no núcleo interfásico (dados não apresentados).

Para o estudo das espécies poliplóides levou-se em consideração que a ocorrência de constrição secundária seja o resultado imediato de regiões ativas na interfase anterior. A ocorrência de constrição secundária tem sido apresentada como o resultado da atividade nucleolar em uma série de trabalhos triticale. Neste híbrido interespecífico Lacadena et al. (1984), Cermeño et al. (1984), Cermeño et al. (1987), Lima-Brito et al. (1998) e Pikaard (1999) mostram que as espécies envolvidas no híbrido, Triticum aestivum e Secale cereale, normalmente apresentam suas regiões organizadoras do nucléolos ativas na forma de constrição secundária, entretanto no híbrido as constrições secundárias dos cromossomos de Secale cereale desaparecem, permanecendo ativas e com constrição secundária somente os cromossomos provenientes do Triticum aestivum. Estes trabalhos demonstram que um genoma pode ser dominante em relação ao outro, tal como observado para o triticale (Triticum $\mathbf{x}$ Secale) onde os lócus de rDNA do genoma do trigo dominam os do centeio tornando-os inativos (Lacadena et al., 1984; Cermeño et al., 1984; Cermeño et al., 1987). O mesmo evento é observado em tritordeum, que são híbridos entre triticales e espécies do gênero Hordeum, onde os rDNAs de centeio nunca se expressam, mas os do trigo e da cevada são ativos conjuntamente (Lima-Brito et al., 1998).

Existem suposições de que esta dominância esteja sobre o controle de genes em um dos genomas (Neves et al., 1997). Entretanto, ao que tudo indica o evento de dominância nucleolar continuará sendo estudado como um evento epigenético, controlado de forma muito intensa pela metilação e a desacetilação de histonas ( revisão em Pikaard, 1999).

A alopoliploidização seja ela surgida por hibridação interespecifica ou intergenérica seguida de duplicação dos cromossomos, está sempre associada com alterações genômicas, tais como eliminação de seqüências, ativação de transposons, co- 
conversão intergenômica, metilação, silenciamento gênico e mudanças na expressão gênica (Shaked et al., 2001).

Sabe-se que a condição poliplóide não é o melhor estado para a manutenção de uma espécie, pelo menos do ponto de vista cromossômico. A ocorrência de multivalentes na meiose devido à homeologia trariam irregularidades cromossômicas $\mathrm{e}$ conseqüentemente perda da viabilidade do híbrido. Entretanto, existem mecanismos genéticos no controle do pareamento cromossômico, principalmente em espécies alopoliplóides, que permitem somente a sinapse entre cromossomos homólogos, promovendo um comportamento diplóide, como é o caso do gene $P h l$ descrito em trigo. Além deste mecanismo genético, existem outros mecanismos que operam no comportamento diplóide ou até mesmo na diploidização das espécies, tal como a regulação da expressão gênica e a eliminação de seqüências (Feldman et al., 1997). Alguns processos podem reduzir o nível de expessão dos genes para um estado diplóide, como a metilação e da desacetilação de histonas, sendo que neste caso, embora o genoma seja poliplóide com relação à quantidade de material genético e número de cópias dos genes, o seu comportamento gênico e cromossômico será estritamente diplóide (Leitch \& Bennett, 1997). O processo de regulação da expressão gênica através da inativação de genes por metilação e desacetilação de histonas seria importante para acentuar as diferenças entre os cromossomos homeólogos nos organismos poliploides, facilitando o correto pareamento dos cromossomos durante a meiose (Feldman et al., 1997). Se este é o caso, nós poderíamos esperar ver evidencias de substancial diploidização, através da inativação de genes e perdas de seqüências de DNA, ocorrendo logo na primeira geração após a diploidização (Eckardt, 2001). E isto é o que realmente ocorre nos poliplóides recém formados.

Uma série de trabalhos sintetizando novamente o trigo, através de cruzamentos dos seus prováveis ancestrais, tem servido como material para o entendimento dos estágios iniciais de formação de um alopoliplóide (Feldman et al., 1997; Ozkan et al., 2001; Shaked et al., 2001; Kashkush et al., 2002). Estes trabalhos têm mostrado que existe um controle muito bem orquestrado de silenciamento e eliminação de seqüências dos genomas. As perdas e silenciamentos tanto ocorrem em regiões codantes tais como 
genes de rRNA, metablismo, resistência a doenças e controle do ciclo celular (Kashkush et al., 2002), bem como regiões de DNA altamente repetitivo (Ozkan et al., 2001; Shaked et al., 2001; Kashkush et al., 2002). Estas perdas e silenciamentos ocorrem de forma unidirecional de um genoma sobre o outro (Ozkan et al., 2001).

A metilação está fortemente associada à inativação dos genes, mas, além disso, grande parte dos genes eliminados estavam primariamente associados com a metilação (Kashkush et al., 2002), indicando que este deve ser um dos requisitos para a eliminação de um segmento de DNA do genoma. Mais ainda, a metilação seria como um relógio marcando o tempo para a eliminação de uma seqüência, pois eliminações destas seqüências foram observadas até a sexta geração após a formação do alopoliplóide (Ozkan et al., 2001).

A direção das eliminações indica que no nivel diplóide, existe uma condição pré-adptativa para as mudanças genomicas e a pré-determinação da direção de eliminação, ou seja, a condição de dominância de um genoma sobre o outro existe antes da formação do poliplóide, mas somente é expressa quando os dois genomas que irão compor o poliplóide se encontram no núcleo (Ozkan et al., 2001). As perdas de seqüências de DNA não ocorrem ao acaso no genoma dos alopoliplóides, apresentam alta repetibilidade para as seqüências que são eliminadas, isto testado para vários alopoliplóides re-sintetizados (Ozkan et al., 2001; Shaked et al., 2001; Kashkush et al., 2002).

Após estas eliminações e silenciamentos iniciais, em uma escala de tempo evolutiva o processo de diploidização continuaria ocorrendo de modo a homogeneizar os genomas e tornar uma planta estritamente diplóide. Isto é muito bem descrito para a espécie Nicotiana tabacum, que possui apenas um lóco de rDNA de 45S e um complexo conjunto de translocações entre os cromossomos das espécies ancestrais (Leitch \& Bennett, 1997; Lim et al., 2000).

A eliminação de locos dos rDNA de $45 \mathrm{~S}$ têm sido descrito para uma série de gêneros com espécies poliplóides, tais como em Hordeum (Taketa et al., 1999); Trifolium (Ansari et al., 1999); Brassica (Snowdon et al., 2000) e Pinus (Liu et al., 2003). O caso mais curioso ocorre em Scilla autumnalis, onde os poliplóide naturais e os 
artificiais perdem um dos locos de rDNA logo na primeira geração de alopoliploidia, as análises citogenéticas indicam que esta perda inclui as regiões heterocromáticas adjacentes à constrição secundaria que ocorre no parental diplóide (Vaughan et al., 1993). Este é o caso mais extremo de perda de rDNA de $45 \mathrm{~S}$ conhecido em plantas, já que os demais exemplos tratam de perdas que ocorreram ao longo da história evolutiva de cada espécie.

Assim podemos dizer que a espécie $C$. stipularia representaria o estado de diploidização extrema, em comparação com a espécie diplóide $C$. juncea. No caso de $C$. paulina, onde se observa um número intermediário de locos de rDNA de 45S, supõemse que esta espécie não atingiu o estágio máximo de diploidização e trata-se de um intermediário. As eliminações estariam ocorrendo no sentido de se acentuar a diferença entre os cromossomos homeólogos como sugerido nos trabalhos anteriormente descritos, uma vez que a eliminação de seqüências de rDNA ocorre entre cromossomos homeólogos.

Muitos poliplóides têm origem polifilética, tendo sido formados de modo recorrente por parentes diplóides geneticamente distintos (Soltis \& Soltis, 2000). Isto permitiria que $C$. stipularia tivesse se originado tanto na Índia, como na América independentemente, tal como mostra os tipos botânicos descritos por Lewis (1987).

Concluindo, os estudos sobre origem e evolução dos alopoliplóides indicam que a estabilização do alopoliplóide envolve dois grandes eventos: (1) diploidização cromossômica, no qual o pareamento de cromossomos homeólogos é supresso, e isto leva a uma condição de pareamento semelhante a das espécies diplóides, formando exclusivamente bivalentes de cromossomos homólogos e (2) diploidização genética, no qual, genes duplicados, incluindo sítios adicionais de rDNA, são silenciados, ou têm sua expressão reduzida, ou são eliminados do genoma. 


\section{CONCLUSÃO}

As técnicas de bandamento-C, coloração com fluorocromos e FISH de rDNAs de $45 \mathrm{~S}$ e $5 \mathrm{~S}$, permitiram um mapeamento detalhado da estrutura dos cromossomos de espécies do gênero Crotalaria, onde foram identificadas regiões de heterocromatinas ricas em GC em um grupo de espécies e de heterocromatinas ricas em AT na espécie $C$. incana. Estes marcadores dão suporte a subdivisão do gênero em seções e subseções, sendo que dentro de cada uma destas divisões foram identificados marcadores cromossômicos específicos. Além disso, foi possível traçar um panorama da evolução destas espécies, indicando que há ganhos e perdas de DNA durante a história evolutiva das espécies independentemente do seu grau de ploidia. Por último, observou-se que as espécies poliplóides estão em processo de diploidização, constatado através da perda de locos de rDNA de 45S em relação à espécie diplóide estudada da mesma seção botânica.

Certamente, estas observações abrem a perspectiva para que um número maior de espécies sejam analisadas com estes e outros marcadores, de modo que as questões não resolvidas neste trabalho possam ser esclarecidas. 


\section{REFERÊNCIAS BIBLIOGRÁFICAS}

AGUIAR-PERECIN, M.L.R. C-banding in maize. I. Band patterns. Caryologia, v.38, p.23-30, 1985.

AGUIAR-PERECIN, M.L.R.; VOSA, C.G. C-banding in maize. II. Identification of somatic chromosomes. Heredity, v.54, p.37-42, 1985.

AHMAD, F.; ACHARYA, S.N.; MIR, Z.; MIR, P.S. Localization and activity of rRNA genes on fenugreek (Trigonella foenum-graecum L.) chromosomes by fluorescent in situ hybridization and silver staining. Theoretical and Applied Genetics, v.98, p.179-185, 1999.

ALI, H.B.; MEISTER, A.; SCHUBERT, I. DNA content, rDNA loci, and DAPI bands reflect the phylogenetic distance between Lathyrus species. Genome, v.43, p.1027$1032,2000$.

ANSARI, H.A.; ELLISON, N.W.; READER, S.M.; BADAEVA, E.D.; FRIEBE, B.; MILLER, T.E.; WILLIANS, W.M. Molecular cytogenetic organization of 5S and 18S-26S rDNA loci in white clover (Trifolium repens L.) and related species. Annals of Botany, v.83, p.199-206, 1999.

ATCHINSON, E. Studies in the Leguminosae. V. Cytological observations on Crotalaria. Journal of the Elisha Mitchell Science Society, v.66, p.70-75, 1950.

BAIRIGANJAN, G. C.; PATNAIK, S. N. Chromosomal evolution in Fabaceae. Cytologia, v.54, p.51-64, 1989. 
BANDEL, G. Variação numérica de cromossomos e evolução nas leguminosas. Piracicaba, 1972. 138p. Tese (Doutorado) - Escola Superior de Agricultura "Luiz de Queiroz", Universidade de São Paulo.

BAUCHAN, G.R.; HOSSAIN, M.A. Constitutive heterochromatin DNA polimorphisms in diploid Medicago sativa ssp. falcata. Genome, v.42, p.930-935, 1999.

BENNETT, M.D.; LEITCH, I.J. Nuclear DNA Amounts in Angiosperm. Annals of Botany, v.76, p.113-176, 1995.

BENNETT, M.D.; LEITCH, I.J. Nuclear DNA Amounts in Angiosperm - 583 New estimates. Annals of Botany, v.80, p.169-196, 1997.

BERNARDELLO, L.M.; STIEFKENS, L.B.; PIOVANO, M.A. Números cromosómicos en dicotiledóneas Argentinas. Boletín de la Sociedad Argentina de Botánica, v.26, p.149-157, 1990.

BERTÃO, M.; AGUIAR-PERECIN, M.L.R. Maize somatic chromosome preparation: pretreatments and genotypes for obtation of high index of metaphase accumulation. Caryologia, v.55 p.115-119, 2002.

BISBY, F.A. The evaluation and selection of characters in Angiosperm taxonomy: an example from Crotalaria L. New Phytologist, v.69, p.1149-1160, 1970.

BISBY, F.A. The role of taximetrics in angiosperm taxonomy. I. Empirical comparisons of methods using Crotalaria L. New Phytologist, v.72, p.699-726, 1973.

BISBY, F.A.; POLHILL, R.M. The role of taximetrics in angiosperm taxonomy. II. Parallel taximetric and orthodox studies in Crotalaria L. New Phytologist, v.72, p.727-742, 1973.

BOULTER, D.; DERBYSHIRE, E.; FRAHM-LELIVELD, J.A.; POLHILL, R.M. Observations on the cytology and seed-proteins of various African species of Crotalaria L. (Leguminosae). New Phytologist, v.69, p.11 7-131, 1970.

CEQUEA, H.; NIRCHIO, T. Cytogenetic analysis of the natural tetraploid Crotalaria stipularia. Acta Científica Venezolana, v.49, p. 38-41, 1998. 
CERBAH, M.; COULAUD, J.; MUGNIER, C.; SILJAK-YAKOVLEV, S. Genome size, fluorochrome banding and karyotype evolution in some Hypochaeris species. Genome, v.38, p.689-695, 1995.

CERBAH, M.; COULAUD, J.; SILJAK-YAKOVLEV, S. rDNA organization and evolutionary relationships in the genus Hypochaeris (Asteraceae). The Journal of Heredity, v.89, p.312-318, 1998.

CERMEÑO, M.C.; FRIEBE, B.; ZELLER, F.J.; KROLOW, K. D. Nucleolar competition in different $(\mathrm{A} / \mathrm{B})(\mathrm{A} / \mathrm{B}) \mathrm{RR}$ and DDRR tetraploid triticales. Heredity, v.58, p.1-4, 1987.

CERMEÑO, M.C.; ORELLANA, J.; SANTOS, J.L.; LACADENA, J.R. Nucleolar organizer activity in wheat, rye and derivatives analyzed by silver-staining procedure. Chromosoma, v.89, p.370-376, 1984.

CHEN, Z.J.; COMAI, L.; PIKAARD, C.S. Gene dosage and stochastic effects determine the severity and direction of uniparental ribosomal RNA gene silencing (nucleolar dominance) in Arabidopsis allopoliploids. Proceedings National Academy of Science USA, v.95, p.14891-14896, 1998.

CHEN, Z.Y.; HUANG, S.F. The karyotypes of five cultivated plants. Acta Botanica Austro Sinica, v. 4, p.75-83, 1989.

CHENNAVEERAIAH, M.S.; PATIL, B.C. Chromosome number and karyotype study in eight species of Crotalaria. Cytologia, v.38, p.73-79, 1973.

CREMONINI, R.; CASTIGLIONI, M.R.; VENORA, G.; BLANGIFORTI, S.; LOSAVIO, F.P.; PIGNONE, D. Cytology of Vicia species. VI. Nuclear chromatin organization, karyomorphological analysis and DNA amount in Vicia serratifolia Jacq. Caryologia, v.51, p.195-205, 1998.

CREMONINI, R.; FUNARI, S.; GALASSO, I.; PIGNONE, D. Cytology of Vicia species II. Banding patterns and chromatin organization in Vicia atropurpurea Desf. Heredity, v.70 p.628-633, 1993. 
CREMONINI, R.; MIOTTO, D.; NGU, M.A.; TOTA, D.; PIGNONE, D.; BLANGIFORTI, S.; VENORA, G. Cytology of Vicia species. V. Nuclear chromatin structure, karyomorphological analysis and DNA content in newly discovered relatives of Vicia faba L.: Vicia kalakhensis Khattab, Maxted et Bisby and Vicia eristalioides Maxted. Cytologia, v.63, p.371-379, 1998.

CUSTÓDIO, A.V.C.; ALVES, M.A.O.; NUNES, E.P.; BARBOSA E SILVA, F.E. Número cromossômico de seis espécies de leguminosas do Ceará. Ciência e Cultura, v. 41, p.684, 1989.

DATTA, R.M.; BISWAS. P.K. Karyotypic study in the genus Crotalaria. II. Caryologia, v.16, p.701-705, 1963.

DATTA, R.M.; CHOUDHURY, P.C. Karyotype in Crotalaria. Bulletin of the Torrey Botanical Club, v.93, p.241-243, 1966.

DATTA, R.M.; GANGULY, P.K. Karyotypic study in the genus Crotalaria. I. Broteria, v.16, p.39-46, 1967.

DATTA, R.M.; GHOSAHAL, K.K. Karyotypic study in the genus Crotalaria. III. Zeitschrift fur Pflanzenzuchtung, v.61, p.58-62, 1969.

DOUDRICK, R.L.; HESLOP-HARRISON, J.S.; NELSON, C.D.; SCHMIDT, T.; NANCE, W.L.; SCHWARZACHER, T. Karyotype of slash pine (Pinus elliottii var. ellioti) using patterns of fluorescence in situ hybridization and fluorochrome banding. The Journal of Heredity, v.86, p.289-296, 1995.

DUBCOVSKY, J.; DVORÁK, J. Ribosomal RNA multigene loci: Nomads of the Triticeae genomes. Genetics, v.140, p.1367-1377, 1995.

ECKARDT, N.A. A sense of self: The role of DNA sequence elimination in allopolyploidization. The Plant Cell, v.13, p.1699-1703, 2001.

FALISTOCCO, E.; FALCINELLI, M. Karyotype and C-banding in Medicago noëana Boiss., Leguminosae. Cytologia, v.58, p.151-154, 1993. 
FELDMAN, M.; LIU, B.; SEGAL, G.; ABBO, S.; LEVY, A.A.; VEJA, J.M. Rapid elimination of low-copy DNA sequences in polyploid wheat: A possible mechanism for differentiation of homeologous chromosomes. Genetics, v.147, p.1381-1387, 1997.

FLAVELL, R.B. Variation in structure and expression of ribosomal DNA loci in wheat. Genome, v.31,p.963-968, 1989.

FORNI-MARTINS, E.R.; GUERRA, M. Longitunal differentiation in chromosomes of some Sesbania Scop. Species. Caryologia v.52, p.97-103, 1999.

FREDIANI, M.; GELATI, M.T.; MAGGINI, F.; GALASSO, I.; MINELLI, S.; CECCARELLI, M.; CIONINI, P.G. A family of dispersed repeats in the genome of Vicia faba: structure, chromosomal organization, redundancy modulation, and evolution. Chromosoma, v.108, p.317-324, 1999.

FRIEBE, B.; ENDO, T.R.; GILL, B.S. Chromosome-Banding Methods. In: Fukui, K.; Shigeki, N. (Ed.) Plant chromosomes: laboratory methods. Boca Raton: CRC Press, 1996. cap.7, p.123-154.

FRIEBE, B.; GILL, B.S. Chromosome banding and genome analysis in diploid and cultivated polyploids wheats. In: P.P. JAUHAR (Ed.) Methods of genome analysis in plants. Boca Raton: CRC Press, 1997. cap.3, p.39-60.

FUCHS, J.; KÜHNE, M.; SCHUBERT, I. Assignment of linkage groups to pea chromosomes after karyotyping and gene mapping by fluorescent in situ hibridization. Chromosoma, v.107, p.272-276, 1998a.

FUCHS, J.; STREHL, S.; BRANDES, A.; SCHWEIZER, D.; SCHUBERT, I. Molecular-cytogenetic characterization of the Vicia faba genome - heterochromatin differantiation, replication patterns and sequence localization. Chromosome Research, v.6, p.219-230, 1998 b.

GALASSO, I.; HARRISON, G.E.; PIGNONE, D.; BRANDES, A.; HESLOPHARRISON, J.S. The distribution and organization of Tyl-copia-like 
retrotransposable elements in the genome of Vigna unguiculata (L.) Walp. (Cowpea) and its relatives. Annals of Botany, v.80, p.327-333, 1997.

GALASSO, I.; PIGNONE, D.; PERRINO, P. Cytotaxonomic studies in Vigna. I. General technique and Vigna unguiculata C-banding. Caryologia, v.45, p.155-161, 1992.

GALASSO, I.; PIGNONE, D.; PERRINO, P. Cytotaxonomic studies in Vigna. II. Heterochromatin characterization in Vigna unguiculata and three related wild species. Caryologia, v.46, p.275-282, 1993.

GALASSO, I.; SAPONETTI, L.S.; PIGNONE, D. Cytotaxonomic studies in Vigna. IV. Variation of the number of active and silent rDNA sites in Vigna unguiculata populations. Caryologia, v.51, p.95-104, 1998.

GALASSO, I.; SCHMIDT, T.; PIGNONE, D. Identification of Lens culinares ssp. Culinares chromosomes by physical mapping of repetitive DNA sequences. Chromosome Research, v.9, p.199-209, 2001.

GALASSO, I.; SCHMIDT, T.; PIGNONE, D.; HESLOP-HARRISON, J.S. The molecular cytogenetics of Vigna unguiculata (L.) Walp: the physical organization and characterization of 18s-5.8s-25s rRNA genes, 5s rRNA genes, telomere-like sequences, and a family of centromeric repetitive DNA sequences. Theoretical and Applied Genetics, v.91, p.928-935, 1995.

GOLDBLATT, P. Cytology and phylogeny of Leguminosae. In: POLHILL, R.M.; RAVEN, P.H. (Ed.) Advances in legume systematics. Kew: Royal Botanic Gardens, 1981. cap.55, p.427-463.

GORTNER, G.; NENNO, M.; WEISING, K.; ZINK, D.; NAGL, W.; KAHL G. Chromosomal localization and distribution of simple sequence repeats and the Arabidopsis-type telomere sequence in the genome of Cicer arietinum L. Chromosome Research, v.6, p.97-104, 1998. 
GUERRA, M. Patterns of heterochromatin distribution in plant chromosomes. Genetics and Molecular Biology, v.23, p.1029-104 1, 2000.

GUPTA, P.K. Nuclear DNA, nuclear area and nuclear dry mass in thirteen species of Crotalaria (Angiospermae, Leguminosae). Chromosoma, v.54, p.155-164, 1976.

GUPTA, R.; GUPTA, P.K. Karyotype Studies in the Genus Crotalaria Linn. Cytologia, v.43, p.357-369, 1978a.

GUPTA, R.; GUPTA, P.K. Pachytene karyotype in the genus Crotalaria L (Leguminosae). Cytologia, v.43, p.655-663, 1978 b.

HALL, K.J.; PARKER, J.S. Stable chromosome fission associated with rDNA mobility. Chromosome Research, v.3, p.417-422, 1995.

HESLOP-HARRISON, J.S. Comparative genome organization in plants: From sequence and markers to chromatin and chromosomes. The Plant Cell, v.12, p.617-635, 2000.

HOWELL , W.M.; BLACK, D. A. Controlled silver-staining of nucleolus organizer regions with a protective colloidal developer: A 1-step method. Experientia, v.36, p.1014, 1980.

HUSAINI, S.W.; GILL, L.S. Cyto-morphological studies of the genus Crotalaria L. (Leguminosae) from Nigeria. Boletim da Sociedade Broteriana, v.58, p.149-172, 1985.

HUSAINI, S.W.; IWO, G.A. Cytomorphological studies of some weedy species of the family Leguminosae from Jos Plateau, Nigeria. Feddes Repertorium, v.103, p.111$120,1992$.

JAHAN, B.; VAHIDY, A.A.; ALI, S.I. Chromosome numbers in some taxa of Fabaceae mostly native to Pakistan. Annals of the Missouri Botanical Garden, v.81, p.792$799,1994$.

KAR, K.; SEN, S.A. comparative karyological study of root and embryo tissue of a few genera of Leguminosae. Cytologia, v.56, p.403-408, 1991. 
KASHKUSH, K.; FELDMAN, M.; LEVY, A.A. Gene loss, silencing and activation in a newly synthesized wheat allotetraploid. Genetics, v.160, p.1651-1659, 2002.

KENTON A. Heterochromatin accumulation, disposition and diversity in Gibasis karwinskyana (Commelinaceae). Chromosoma, v.100, p.467-478, 1991.

KHATOON, S.; ALI, S.I. Chromosome numbers in subfamily Papilionoideae (Leguminosae) from Pakistan. Willdenowia, v.20, p.159-165, 1991.

KHATOON, S.; ALI, S.I. Chromosome numbers of some plants of Pakistan. Pakistan Journal of Botany, v.14, p.117-129, 1982.

KUMARI, S.; BIR, S.S. Karyomorphological evolution in Papilionaceae. Journal of Cytology and Genetics, v.25, p.173-219, 1990.

LACADENA, J.R.; CERMEÑO, M.C.; ORELLANA, J.; SANTOS, J.L. Evidence for wheat-rye nucleolar competition (amphiplasty) in triticale by silver-staining procedure. Theoretical and Applied Genetics, v.67, p.207-213, 1984.

LEITCH, I.J.; BENNETT, M.D. Polyploidy in angiosperms. Trends in Plant Science, v.2, p.470-476, 1997.

LEWIS, G.P. Legumes of Bahia. Kew: Royal Botanic Gardens, 1987. 369p.

LEWIS, M.S.; PIKAARD, C.S. Restricted chromosomal silencing in nucleolar dominace. Proceedings National Academy of Science USA, v.98, p.14536-14540, 2001.

LI, J.Q. On the karyotypes in six species of Crotalaria L. in Yunnan. Journal of Wuhan Botanical Research, v.6, p.13-20, 1988.

LIM, K.Y.; MATYÁSEK, R.; LICHTENSTEIN, C.P.; LEITCH, A.R. Molecular cytogenetic analyses and phylogenetic studies in the Nicotiana section Tomentosae. Chromosoma, v.109, p.245-258, 2000.

LIMA-BRITO, J.; GUEDES-PINTO, H.; HESLOP-HARRISON, J.S. The activity of nucleolar organizing chromosomes in multigeneric $F_{1}$ hybrids involving wheat, triticale, and tritordeum. Genome, v.41, p.763-768, 1998. 
LIU, Z.L.; ZHANG, D.; HONG, D.Y; WANG, X.R. Chromosomal localization of 5S and 18S-5.8S-25S ribosomal DNA sites in five Asian pines using fluorescent in situ hybridization. Theoretical and Applied Genetics, v.106, p.198-204, 2003.

MALUSZYNSKA, J.; HESLOP-HARRISON, J.S. Molecular cytogenetics of the genus Arabidopsis: In situ localization of rDNA sites, chromosome number and diversity in centromeric heterochromatin. Annals of Botany, v.71, p.479-484, 1993.

MANGOTRA, R.; KOUL, A. Base number in the genus Crotalaria - evidences from meiosis. The Nucleus, v.34, p.158-161, 1991.

MEDINA, J.C. Plantas Fibrosas da Flora Mundial. São Paulo: Industria Gráfica Siqueira, 1959. 913p.

MILNE-REDHEAD, E. Miscellaneous notes on African species of Crotalaria L.: I. Kew Bulletin, v. 15, p.157-167, 1961.

MISSOURI BOTANICAL GARDEN. Index to Plant Chromosome Numbers (IPCN). http://mobot.mobot.org/W3T/Search/ipen.html (acessado em junho, 2003).

MO, H.K.; LI, Q.Q.; ZHANG, Q.M. Karyotype analysis of Crotalaria anagyroides. Guihaia, v.7, p.205-207, 1987.

MOSCONE, E.A.; KLEIN, F.; LAMBROU, M.; FUCHS, J.; SCHWEIZER, D. Quantitative karyotyping and dual-color FISH mapping of 5S and 18s-25S rDNA probes in the cultivated Phaseolus species (Leguminosae). Genome, v.42, p.1224$1233,1999$.

MURRAY, B.G.; BENNETT, M.D.; HAMMETT, R.W. Secondary constrictions and NORs of Lathyrus investigated by silver staining and in situ hybridization. Heredity, v.68, p.473-478, 1992

NARAYAN, R.K.J. Chromosome changes in the evolution of Lathyrus species. In: BRANDHAM, P.E.; BENNETT, M.D. (Ed.) Kew Chromosome Conference II. Boston: George Allen \&Unwin Publishers, 1983. cap.30, pp. 243-250.

NARAYAN, R.K.J. Discontinous DNA variation in the evolution of plant species: the genus Lathyrus. Evolution, v.36, p877-891, 1982. 
NARAYAN, R.K.J. The role of genomic constraints upon evolutionary changes in genome size and chromosome organization. Annals of Botany, v.82, p.57-66, 1998. Suplemment A

NARAYAN, R.K.J.; DURRANT, A. DNA distribution in chromosomes of Lathyrus species. Genetica, v.61, p.47-53, 1983.

NARAYAN, R.K.J.; McINTYRE, F.K. Chromosomal DNA variation, genomic constraints and recombination in Lathyrus. Genetica, v.79, p.45-52, 1989.

NAVRÁTILOVÁ, A.; NEUMANN, P.; MACAS, J. Karyotype analysis of four Vicia species using in situ hybridization with repetitive sequences. Annals of Botany, v.91, p.921-926, 2003.

NEVES, N.; SILVA, M.; HESLOP-HARRISON, J.S.; VIEGAS, W. Nucleolar dominance in triticales: control by unliked genes. Chromosome Research, v.5, p.125-131, 1997.

OLIVEIRA, A. L. P. C.; AGUIAR-PERECIN, M. L. R. Estudos citogenéticos em 5 espécies do gênero Crotalaria (Leguminosae). Ciência e Cultura, v.41, p.678, 1989.

OLIVEIRA, A.L.P.C. Evolução cariotípica no gênero Crotalaria L. (Leguminosae). Piracicaba, 1992. 113p. Tese (Doutorado) - Escola Superior de Agricultura "Luiz de Queiroz", Universidade de São Paulo.

OLIVEIRA, A.L.P.C.; AGUIAR-PERECIN, M.L.R. Karyotype evolution in the genus Crotalaria L. Cytologia, v.64, p.164-174, 1999.

OZKAN, H.; LEVY, A.A.; FELDMAN, M. Allopolyploidy-induced rapid genome evolution in the wheat (Aegilops-Triticum) group. The Plant Cell, v.13, p.1735$1747,2001$.

PALOMINO, G.; VÁZQUEZ, R. Cytogenetic Studies in Mexican Populations of Species of Crotalaria L. (Leguminosae-Papilionideae). Cytologia, v.56, p.343-351, 1991. 
PATIL, B. C. Cytology and nature of ploidy in three species of Crotalaria. Journal Japanese of Botany, v.62, p.55-62, 1987.

PATIL, B. C. Cytomixis in Crotalaria Linn. Journal of Cytology and Genetics, v.18, p.79-85, 1983.

PATIL, B.G.; CHENNAVEERAIAH, M.S. Cytological studies in Crotalaria incana L. and C. mucronata Desv. The Nucleus, v.18, p.141-146, 1975.

PEARCE, S.R.; HARRISON, G.; LI, D.; HESLOP-HARRISON, J.S.; KUMAR, A.; FLAVELL, A.J. The Tyl-copia group retrotransposons in Vicia species: copy number, sequence heterogeneity and chromosomal localization. Molecular and General Genetics, v.250, p.305-315, 1996.

PEDROSA, A.; SANDAL, N.; STOUGAARD, J.; SCHWEIZER, D.; BACHMAIR, A. Chromosomal map of the model legume Lotus japonicus. Genetics, v.161, p.1661$1672,2002$.

PEDROSA, A.; VALLEJOS, C.E.; BACHMAIR, A.; SCHWEIZER, D. Integration of common bean (Phaseolus vulgaris L.) linkage and chromosomal maps. Theoretical and Applied Genetics, v.106, p.205-212, 2003.

PIKAARD, C.S. Nucleolar dominance and silencing of transcription. Trends in Plant Science, v.4, p.478-483, 1999.

PODLECH, D. Chromosomenstudien en Pflanzen des Saharo-Sindischen Trockengebietes. Mitteilungen der Botanischen Staatssammlung München, v. 22, p.5-20, 1986

POLHILL, R.M. Crotalaria in Africa and Madagascar. Rotterdam: A.A. Balkeama, 1982. 389p.

POLHILL, R.M. Crotalarieae (Benth.) Hutch. (1964). In: POLHILL, R.M.; RAVEN, P.H. (Ed.) Advances in legume systematics. Kew: Royal Botanic Gardens, 1981. Tribe 29, p.399-402. 
POLHILL, R.M. Genisteae (Adans.) Benth. and related tribes (Leguminosae). Botanical Systematics, v.1, p.143-368, 1976.

POLHILL, R.M. Miscellaneous notes on African species of Crotalaria.: II. Kew Bulletin, v.22, p.169-348, 1968.

POLHILL, R.M.; RAVEN, P.H. Advances in legume systematics. Parte 1. Kew: Royal Botanic Gardens, 1981. 424p.

POLHILL, R.M.; RAVEN, P.H.; STIRTON, C.H. Evolution and sistematics of the Leguminosae. In: POLHILL, R.M.; RAVEN, P.H. (Ed.) Advances in legume systematics. Kew: Royal Botanic Gardens, 1981. cap.1, p.1-26.

RAINA, S.N.; MUKAI, Y. Detection of a variable number of 18S-5.8S-26S and 5S ribosomal DNA loci by fluorescent in situ hybridization in diploid and tetraploid Arachis species. Genome, v.42, p.52-59, 1998.

RAINA, S.N.; MUKAI, Y.; KAWAGUCHI, K.; GOEL, S.; JAIN, A. Physical mapping of $18 \mathrm{~S}-5.8 \mathrm{~S}-26 \mathrm{~S}$ and $5 \mathrm{~S}$ ribosomal RNA gene families in three important vetches (Vicia species) and their allied taxa constituting three species complexes. Theoretical and Applied Genetics, v.103, p.839-845, 2001.

RAINA, S.N.; VERMA, R.C. Cytogenetics of Crotalaria I. Mitotic complements in twenty species of Crotalaria L. Cytologia, v.44, p.365-375, 1979.

ROOSE, M.L.; SCHWARZACHER, T.; HESLOP-HARRISON, J.S. The chromosomes of Citrus and Poncirus species and hybrids: identification of characteristic chromosomes and physical mapping of rDNA loci using in situ hybridization and fluorocrome banding. The Journal of Heredity, v.89, p.83-86.

SANJAPPA, M.; DASGUPTA, A. Chromosome numbers in some Indian legumes. Indian Journal of Botany, v. 6, p.61-64, 1983.

SCHUBERT, I. Mobile nucleolus organizing regions (NORs) in Allium (Liliaceae s. lat.)? - Inferences from specificity of silver staining. Plant Systematic and Evolution, v.144, p.291-305. 
SCHUBERT, I.; RIEGER, R. Alterations by centric fissions of the diploid chromosome number in Vicia faba L. Genetica, v.81, p.67-69, 1990.

SCHUBERT, I.; WOBUS, U. In situ hybridization confirms jumping nucleolus organizing regions in Allium. Chromosoma, v.92, p.143-148, 1985.

SCHWARZACHER, T.; SCHWEIZER, D.; Karyotype analysis and heterochromatin differentiation with giemsa C-banding and fluorescent counterstaining in Cephalanthera (Orchidaceae). Plant Systematic and Evolution, v.141, p.91-113, 1982.

SCHWEIZER D. R-banding produced by DNase I digestion of chromomycin -stained chromosomes. Chromosoma, v.64, p.117-124, 1977.

SCHWEIZER D. Reverse fluorescent chromosome banding with chromomycin and DAPI. Chromosoma, v.58, p.307-324, 1976a.

SCHWEIZER, D. Counterstain-enhanced chromosome banding. Human Genetics, v.57, p.1-14, 1981 .

SCHWEIZER, D. DAPI fluorescence of plant chromosomes prestained with actinomycin D. Experimental Cell Research, v.102, p.408-413, 1976 b.

SCHWEIZER, D. Distamycin-DAPI bands: properties and occurrence in species. In: BRANDhaM, P.E.; BENNETT, M.D. (Ed.) Kew Chromosome Conference II. Boston: George Allen \&Unwin Publishers, 1983. cap.6, p. 43-51.

SCHWEIZER, D.; AMBROS, P.; ANDRLE, M. Modification of DAPI banding on human chromosomes by pre-staining with a DNA-binding oligopeptide antibiotic, distamycin A. Experimental Cell Research, v.111, p.327-332, 1978.

SHAKED, H.; KASHKUSH, K.; OZKAN, H.; FELDMAN, M.; LEVY, A.A. Sequence elimination and cytosine methylation are rapid and reprodusible responses of the genome to wide hybridization and allopolyploidy in wheat. The Plant Cell, v.13, p.1749-1759, 2001. 
SHI, L.; ZHU, T.; KEIM, P. Ribosomal RNA genes in soybean and common bean: chromosomal organization, expression, and evolution. Theoretical and Applied Genetics, v.93, p.136-141, 1996.

SHISHIDO, R.; SANO, Y.; FUKUI, K. Ribosomal DNAs: an exception to the conservation of gene order in rice genomes. Molecular and General Genetics, v.263, p.586-591, 2000.

SIDHU, M.; BIR, S.S. Karyological studies on weeds on cultivable lands in Punjab, India. Tropical Plant Science Research, v.1, p.1-13, 1983.

SILJAK-YAKOVLEV, S.; PECCENINI, S.; MURATOVIC, E.; ZOLDOS, V.; ROBIN, O.; VALLÈS, J. Chromosomal differentiation and genome size in three European mountain Lilium species. Plant Systematic and Evolution, v.236, p.165-173, 2003.

SNOWDON, R.J.; FRIEDT, W.; KÖHLER, A.; KÖHLER, W. Molecular cytogenetic localization and characterization of $5 \mathrm{~S}$ and $25 \mathrm{~S}$ rDNA loci for chromosome identification in Oilseed Rape (Brassica napus L.). Annals of Botany, v.86, p.201204, 2000.

SOLTIS, P.S.; SOLTIS, D.E. The role of genetic and genomic attributes in the sucess of polyploids. Proceedings National Academy of Science USA, v.97, p.7051-7057, 2000.

STEBBINS, G.L. Chromosomal evolution in higher plants. London: Edward Amold Ltd., 1971. 216p.

TAKETA, S.; HARRISON, G.E.; HESLOP-HARRISON, J.S. Comparative physical mapping of the $5 \mathrm{~S}$ and $18 \mathrm{~S}-25 \mathrm{~S}$ rDNA in nine wild Hordeum species and cytotypes. Theoretical and Applied Genetics, v.98, p.1-9, 1999.

TAYYAR R.L., LUKASZEWSKI A.J. AND WAINES J.G., - Chromosome banding patterns in annual species of Cicer. Genome, v.37, p.656-663, 1994.

ÜNAL, F.; WALLACE, A.J.; CALLOW, R.S. Diverse heterochromatin in Lathyrus. Caryologia, v.48, p.47-63, 1995. 
VAUGHAN, H.E.; JAMILENA, M.; REJÓN, C.R.; PARKER, J.S.; GUARRIDORAMOS, M.A. Loss od nucleolar-organizer regions during polyploid evolution in Scilla autumnalis. Heredity, v.71, p.574-580, 1993.

VERMA, R. C.; RAINA, S. N. Cytogenetics of Crotalaria. Cell and Chromosome Newsletter, v. 1, p.32-33, 1978.

VERMA, R.C.; KESAVACHARYULU, K.; RAINA, S.N. Cytogenetics of Crotalaria IX. Mitotic Complements in 19 Species. Cytologia, v.49, p.157-169, 1984.

VERMA, R.C.; RAINA, S.N. Cytogenetics of Crotalaria. II. Male meiosis in 8 species of Crotalaria. Cytologia, v.45, p.297-306, 1980.

VERMA, R.C.; RAINA, S.N. Cytogenetics of Crotalaria. V. Supemumerary nucleoli in C. agatiflora (Leguminosae). Genetica, v.56, p.75-80, 1981.

VERMA, R.C.; RAINA, S.N. Cytogenetics of Crotalaria. VIII. Male meiosis in 26 species. Cytologia, v.48, p.719-733, 1983.

VOSA, C.G. Basic karyotype of rye (Secale cereale) analyzed with giemsa and fluorescence methods. Heredity, v.33, p.403-409, 1975.

WINDLER, D. Chromosome number for native North American unifoliate species of Crotalaria (Leguminosae). Brittonia, v.26, p.172-176, 1974.

YEH, M.S.; YUASA, H.; MAEKAWA, F. Chromosome numbers in the Leguminosae. Scientific Report Research of the Institute of Evolution Biology, v. 3, p.57-71, 1986.

ZHU, B.C. Karyotype analysis of Sunn crotalarias chromosome. Chinese Bulletin of Botany, v. 2, p.39-40, 1984 
APÊNDICES 
APÊNDICE 1 - Revisão do número de $\operatorname{cromossomos}^{1}$ de espécies de Crotalaria, subdivididos dentro de suas respectivas seções e subseções botânicas.

Espécie

n 2n Referências

\section{SEÇÃO GRANDIFLORAE}

C. agatiflora

C. australis

C. barnabassii

C. capensis

C. laburnifolia

C. rosenii

\section{SEÇÃO CHRYSOCALYCINAE}

\section{Subseç̃o Incanae}

C. barkae

C. incana
8

7
16 Bandel, 1972; Verma et al., 1984

16 Verma et al., 1984

16 Boulter et al., 1970; Bandel, 1972

14 Datta \& Ghoshal, 1969; Bandel, 1972

816 Atchinson, 1950; Bandel, 1972; Gupta \& Gupta, 1978; Raina \&Verma, 1979; Bairiganjan \& Patnaik, 1989 Mangotra \& Koul, 1991

16 Boulter et al., 1970
16 Bandel, 1972; Chennaveeraiah \& Patil, 1973; Husaini \& Iwo, 1992

14, 21 Atchinson, 1950; Bandel, 1972; Gupta \& Gupta, 1978; Raina \&Verma, 1979; Patil, 1983; Oliveira \& AguiarPerecin, 1989; Custódio et al., 1989; Bernardello et al., 1990; Mangotra \& Koul, 1991; Palomino \& Vázquez, 1991; Oliveira, 1992; Oliveira \& AguiarPerecin, 1999

14 Boulter et al., 1970; Gupta \& Gupta, 1978

14 Boulter et al., 1970; Gupta \& Gupta, 1978

14 Boulter et al., 1970

14 Boulter et al., 1970

32 Verma et al., 1984

32 Atchinson, 1950; Bandel, 1972

14, 16 Boulter et al., 1970; Bandel, 1972
Subseção Stipulosae

C. cylindrocarpa

C. goreënsis

C. lachnocarpa (C. lachnophora)

C. lachnophora

C. natalitia var. natalitia

C. natalitia var. rutshuruensis

C. podocarpa

C. rhodesiae
Bandel, 1972; Husaini \& Gill, 1985

$8 \quad 16$ Atchinson, 1950; Bandel, 1972; Husaini \& Gill, 1985; Husaini \& Iwo, 1992

16 Bandel, 1972

Husaini \& Gill, 1985

16 Boulter et al., 1970

16 Boulter et al., 1970

16 Bandel, 1972

16 Verma et al., 1984 
APENNDICE 1 - Revisão do número de cromossomos de espécies de Crotalaria, subdivididos dentro de suas respectivas seções e subseções botânicas.

\begin{tabular}{|c|c|c|c|}
\hline Espécie & $\mathbf{n}$ & $2 n$ & Referências \\
\hline \multicolumn{4}{|l|}{ Subseção Glaucae } \\
\hline C. glauca & 8 & & $\begin{array}{l}\text { Bandel, 1972; Husaini \& Gill, 1985; Husaini \& Iwo, } \\
1992\end{array}$ \\
\hline C. glaucoides & & 16 & Bandel, 1972 \\
\hline C. goetzei & & 16 & Boulter et al., 1970 \\
\hline C. lachnocarpoïdes & & 16 & Boulter et al., 1970 \\
\hline C. lachnosema & 8 & & Husaini \& Iwo, 1992 \\
\hline $\begin{array}{l}\text { C. longifoliolata (C. glaucifolia } \\
\text { Polhill, 1971) }\end{array}$ & 8 & & Husaini \& Iwo, 1992 \\
\hline C. orthoclada & & 16 & Boulter et al., 1970 \\
\hline C. ramosissima (C. huillensis) & 8 & 16 & $\begin{array}{l}\text { Sanjappa \& DasGupta, 1983; Bairiganjan \& Patnaik, } \\
1989\end{array}$ \\
\hline C. rotundicarinata $(C$. goetzei) & & 16 & Bandel, 1972 \\
\hline
\end{tabular}

Subseção Chrysocalycinae

C. anagyroides (C. micans Link, 816 Atchinson, 1950; Datta \& Ganguly, 1967; Bandel, 1822) 1972; Gupta \& Gupta, 1978; Raina \&Verma, 1979; Mo et al., 1987; Mangotra \& Koul, 1991; Husaini \& Iwo, 1992

C. atrorubens

C. confusa

C. ebenoïdes

C. ononoïdes

C. perrottetii

C. unifoliata

Subseção Tetralobocalyx

\section{SEÇÃO HEDRIOCARPAE}

Subseção Hedriocarpae

C. burttii

C. comanestiana

C. pycnostachya

C. saharae

C. saltiana

8
$8+1 B$
8

16

Bandel, 1972; Husaini \& Iwo, 1992

Husaini \& Gill, 1985

Bandel, 1972; Husaini \& Iwo, 1992

16 Boulter et al., 1970

16 Boulter et al., 1970; Bandel, 1972

16 Bandel, 1972

\section{Subseção Macrostachyae}

C. acervata (C. subcaptata subsp 8 oradum Bak. f., Polhill, 1968)

C. argyraea
Husaini \& Gill, 1985

Atchinson, 1950; Bandel, 1972 
APÊNDICE 1 - Revisão do número de cromossomos de espécies de Crotalaria, subdivididos dentro de suas respectivas seções e subseções botânicas.

Espécie
C. astragalina (C. subcapitata
subsp. oreadum, C. lathyroides, $C$.
onobrychis $)$
C. balbi
C. brownei

C. cleomifolia

C. comosa

C. dewildemaniana subsp.

oxyrhyncha

C. dilloniana (C. petitiana)

C. distantiflora

C. falcata (C. pallida var. obovata)

C. impressa

C. intermedia (C. brevidens var.intermedia Polhill, 1968)

C. intermedia (C. ochroleuca)

C. kirkii

C. lanceolata n 2n Referências

16 Bandel, 1972

16 Boulter et al., 1970

816 Bandel, 1972; Gupta \& Gupta, 1978; Verma \& Raina, 1978; Raina \&Verma, 1979; Raina \& Verma, 1980

$8 \quad$ Husaini \& Gill, 1985; Husaini \& Iwo, 1992

8 Bandel, 1972; Husaini \& Iwo, 1992

16 Boulter et al., 1970; Gupta \& Gupta, 1978

16 Atchinson, 1950; Bandel, 1972

16 Boulter et al., 1970

16 Boulter et al., 1970; Bandel, 1972; Verma et al., 1984; Husaini \& Iwo, 1992

16 Patil, 1983

16 Atchinson, 1950; Boulter et al., 1970; Bandel, 1972; Gupta \& Gupta, 1978; Verma \& Raina, 1978; Raina \&Verma, 1979; Verma \& Raina, 1980; Husaini \& Iwo, 1992

16 Bandel, 1972

16 Boulter et al., 1970; Gupta \& Gupta, 1978

816 Atchinson, 1950; Boulter et al., 1970; Bandel, 1972; Gupta \& Gupta, 1978; Verma \& Raina, 1978; Raina \&Verma, 1979; Verma \& Raina, 1980; Oliveira \& Aguiar-Perecin, 1989; Oliveira \& Aguiar-Perecin, 1999
C. massaiensis
C. mesopontica
C. mucronata (C. pallida)

C. naragutensis

C. obovata (C. pallida var. obovata)

C. ochroleuca
32 Boulter et al., 1970

16 Bandel, 1972

816 Atchinson, 1950; Bandel, 1972; Gupta \& Gupta, 1978; Raina \&Verma, 1979; Husaini \& Iwo, 1992

Boulter et al., 1970; Bandel, 1972; Husaini \& Iwo, 1992

Atchinson, 1950; Bandel, 1972

16 Boulter et al., 1970; Bandel, 1972; Verma et al., 1984; Mangotra \& Koul, 1991 
APÊNDICE 1 - Revisão do número de cromossomos de espécies de Crotalaria, subdivididos dentro de suas respectivas seções e subseções botânicas.

\begin{tabular}{llll}
\hline Espécie & n & 2n & Referências \\
\hline C. pallida & 8 & 16 & Gupta \& Gupta, 1978; Raina \&Verma, 1979; Li, 1988; \\
& & & Oliveira \& Aguiar-Perecin, 1989; Kumari \& Bir, \\
& & 1990; Bairiganjan \& Patnaik, 1989; Oliveira \& \\
& Aguiar-Perecin, 1999
\end{tabular}

C. pallida var. obovata

C. pallida var. pallida

C. petitiana

C. rogersii

C. spartea

C. striata (C. pallida)

C. usaramoensis (C. zanzibarica)

C. vallicola

C. vatkeana

C. zanzibarica

\section{SEÇÃO GENICULATAE}

C. bongensis

C. leprieurii

C. sphaerocarpa

C. vogelii (C. leprieurii)

\section{SEÇÃO SCHIZOSTIGMA}

\section{SEÇÃO CALYCINAE}

C. aegyptiaca

C. arenaria

C. alata (C. bialata Hara, 1966)

C. albida

C. bifaria

C. breviflora

C. burhia

C. calycina
16 Mangotra \& Koul, 1991

16 Mangotra \& Koul, 1991

16 Boulter et al., 1970; Gupta \& Gupta, 1978

16 Boulter et al., 1970

16 Boulter et al., 1970; Bandel, 1972

816 Bandel, 1972; Gupta \& Gupta, 1978; Raina \&Verma, 1979

816 Atchinson, 1950; Bandel, 1972; Yeh, 1986

16 Boulter et al., 1970

16 Boulter et al., 1970

$8 \quad 16 \quad$ Patil, 1983
Husaini \& Gill, 1985; Husaini \& Iwo, 1992

16 Boulter et al., 1970

16 Boulter et al., 1970; Bandel, 1972; Verma et al., 1984

16 Bandel, 1972

\footnotetext{
16 Boulter et al., 1970; Bandel, 1972

816 Atchinson, 1950; Bandel, 1972

816 Atchinson, 1950; Bandel, 1972; Patil, 1983; Bairiganjan \& Patnaik, 1989

16 Bandel, 1972; Li, 1988; Bairiganjan \& Patnaik, 1989; Kumari \& Bir, 1990

Bandel, 1972; Sanjappa \& DasGupta, 1983

816 Atchinson, 1950; Verma \& Raina, 1978; Verma et al., 1984

816 Datta \& Ghodhury, 1966; Bandel, 1972; Verma \& Raina, 1978; Raina \&Verma, 1979; Verma \& Raina, 1980; Khatoon \& Ali, 1982; Khatoon \& Ali, 1991; Jahan et al., 1994

Boulter et al., 1970; Bandel, 1972; Husaini \& Gill, 1985
} 
APÊNDICE 1 - Revisão do número de cromossomos de espécies de Crotalaria, subdivididos dentro de suas respectivas seções e subseções botânicas.

\begin{tabular}{|c|c|c|c|}
\hline Espécie & $\mathbf{n}$ & $2 n$ & Referências \\
\hline C. juncea & 8 & 16 & $\begin{array}{l}\text { Atchinson, 1950; Datta \& Ganguly, 1967; Bandel, } \\
\text { 1972; Gupta \& Gupta, 1978; Verma \& Raina, 1978; } \\
\text { Raina \&Verma, 1979; Verma \& Raina, 1980; Zhu, } \\
\text { 1984; Yeh et al., 1986; Bairiganjan \& Patnaik, 1989; } \\
\text { Kumari \& Bir, 1990; Mangotra \& Koul, 1991; Kar \& } \\
\text { Sen, 1991; Jahan et al., } 1994\end{array}$ \\
\hline C. mysorensis (C. hirta) & & 16 & $\begin{array}{l}\text { Datta \& Ghoshal, 1969; Bandel, 1972; Gupta \& } \\
\text { Gupta, 1978; Raina \&Verma, 1979; Kumari \& Bir, } \\
1990\end{array}$ \\
\hline C. nitens & 16 & 32 & Chennaveeraiah \& Patil, 1973; Patil, 1983; Patil, 1987 \\
\hline C. orixensis & & 16 & $\begin{array}{l}\text { Bandel, 1972; Chennaveeraiah \& Patil, 1973; Kumari } \\
\& \text { Bir, } 1990\end{array}$ \\
\hline C. paulina & & 32 & $\begin{array}{l}\text { Bandel, 1972; Patil, 1987; Verma et al., 1984; Oliveira } \\
\text { \& Aguiar-Perecin, } 1999\end{array}$ \\
\hline C. polygaloides & 8 & & Husaini \& Gill, 1985 \\
\hline C. sagittalis & 16 & 32 & Bandel, 1972; Windler, 1974; Verma et al., 1984 \\
\hline C. scabrella & 8 & & Sanjappa \& DasGupta, 1983 \\
\hline C. stipularia & 16 & 32 & $\begin{array}{l}\text { Bandel, 1972; Windler, 1974; Verma et al., 1984; } \\
\text { Patil, 1987; Oliveira \& Aguiar-Perecin, 1989; } \\
\text { Custódio et al., 1989; Mangotra \& Koul, 1991; } \\
\text { Oliveira \& Aguiar-Perecin, } 1999\end{array}$ \\
\hline
\end{tabular}

\section{SEÇÃO CROTALARIA}

Subseção Crotalaria

C. fulva (C. berteroana Senn, 1939)

816 Atchinson, 1950; Bandel, 1972; Sanjappa \& DasGupta, 1983

C. grahamiana

16 Bandel, 1972; Chennaveeraiah \& Patil, 1973; Gupta \& Gupta, 1978; Raina \&Verma, 1979; Mangotra \& Koul, 1991

C. ivantalensis

C. lanata (C. lunata)

C. maxillaris (C. emarginella

Polhill, 1968)*

C. quinquefolia

16 Atchinson, 1950; Bandel, 1972

16 Bandel, 1972; Verma et al., 1984

16 Verma et al., 1984

16 Atchinson, 1950; Boulter et al., 1970; Bandel, 1972; Gupta \& Gupta, 1978; Verma et al., 1984; Bairiganjan \& Patnaik, 1989 
APÊNDICE 1 - Revisão do número de cromossomos de espécies de Crotalaria, subdivididos dentro de suas respectivas seções e subseções botânicas.

\begin{tabular}{|c|c|c|c|}
\hline Espécie & n & $2 n$ & Referências \\
\hline C. recta (C. Colorata subsp. erecta) & $7(?)$ & 16 & $\begin{array}{l}\text { Boulter et al., 1970; Bandel, 1972; Raina \&Verma, } \\
\text { 1979; Husaini \& Iwo, } 1992\end{array}$ \\
\hline C. retusa & 8 & 16 & $\begin{array}{l}\text { Atchinson, 1950; Boulter et al., 1970; Bandel, 1972; } \\
\text { Gupta \& Gupta, 1978; Verma \& Raina, 1978;Verma } \\
\text { \& Raina, 1980; Patil, 1983; Husaini \& Gill, 1985; } \\
\text { Bairiganjan \& Patnaik, 1989; Oliveira \& Aguiar- } \\
\text { Perecin, 1989; Mangotra \& Koul, 1991; Husaini \& } \\
\text { Iwo, 1992; Oliveira \& Aguiar-Perecin, 1999 }\end{array}$ \\
\hline
\end{tabular}

C. sericea (C. spectabilis)

C. spectabilis

C. verrucosa
8

8

C. aculeata

C. deserticola subsp. orientalis

C. grantiana (C. virgulata subsp. 8 grantiana)

C. greenwayi

C. laburnoïdes

C. maxillaris (C. senegalensis, C. 8 laburnoides)*

C. spinosa
16 Datta \& Ganguly, 1967; Bandel, 1972; Gupta \& Gupta, 1978; Verma \& Raina, 1978; Raina \&Verma, 1979; Kumari \& Bir, 1990

8 16, 32 Atchinson, 1950; Boulter et al., 1970; Bandel, 1972; Verma et al., 1984; Bairiganjan \& Patnaik, 1989; Mangotra \& Koul, 1991; Palomino \& Vázquez, 1991

16 Atchinson, 1950; Datta \& Biswas, 1963; Bandel, 1972; Gupta \& Gupta, 1978; Verma \& Raina, 1978; Raina \&Verma, 1979; Verma \& Raina, 1980; Bairiganjan \& Patnaik, 1989; Mangotra \& Koul, 1991

\section{SEÇÃO DISPERMAE}

C. argyrolobioides

C. cephalotes

C. cuspidata

C. hyssopifolia

C. kipandensis

C. laxiflora
Boulter et al., 1970; Husaini \& Iwo, 1992

16

16 Bandel, 1972; Atchinson, 1950; Patil, 1983; Verma et al., 1984

16 Boulter et al., 1970; Gupta \& Gupta, 1978

16 Boulter et al., 1970

16 Atchinson, 1950; Boulter et al., 1970; Bandel, 1972; Verma et al., 1984

16 Atchinson, 1950; Boulter et al., 1970; Bandel, 1972; Podlech, 1986

16 Verma et al., 1984

Boulter et al., 1970; Husaini \& Iwo, 1992

16 Boulter et al., 1970

16 Boulter et al., 1970

16 Boulter et al., 1970

16 Boulter et al., 1970 
APÊNDICE 1 - Revisão do número de cromossomos de espécies de Crotalaria, subdivididos dentro de suas respectivas seções e subseções botânicas.

\begin{tabular}{|c|c|c|c|}
\hline Espécie & $\mathbf{n}$ & $2 n$ & Referências \\
\hline C. medicaginea & & 16 & $\begin{array}{l}\text { Bandel, 1972; Gupta \& Gupta, 1978; Raina \&Verma, } \\
\text { 1979; Li, 1988; Bairiganjan \& Patnaik, 1989; } \\
\text { Mangotra \& Koul, 1991 }\end{array}$ \\
\hline C. medicaginea var. luxurians & 8 & 16 & $\begin{array}{l}\text { Khatoon \& Ali, 1982; Sidhu \& Bir, 1983; Kumari \& } \\
\text { Bir, } 1990\end{array}$ \\
\hline C. medicaginea var. medicaginea & 16 & 32 & Kumari \& Bir, 1990; Jahan et al., 1994 \\
\hline C. prolongata & & 16 & Boulter et al., 1970 \\
\hline C. trifoliastrum & & 16 & Bandel, 1972; Verma et al., 1984 \\
\hline
\end{tabular}

\section{SEÇÕES NÃO DEFINIDAS}

C. amazonas

C. assamica

C. brachystachya

C. bracteata

C. brevifolia

C. bupleurifolia

C. candicans

C. ferruginea

C. ferruginea var. pilosissima

C. formosa

C. heyneana

C. hirsuta

C. leptostachya

C. leschenaultii

C. linifolia

C. longirostrata

C. madurensis

C. nana

C. nayaritensis

C. paniculata

C. polyphylla

C. prostrata

C. pulcherrima

C. pumila
16 Bandel, 1972

16 Chen \& Huang, 1989

16 Verma et al., 1984

16 Li, 1988

816 Bandel, 1972; Gupta \& Gupta, 1978; Verma \& Raina, 1979; Verma \& Raina, 1980

16 Windler, 1974

16 Mangotra \& Koul, 1991

1648 Datta \& Ghoshal, 1969; Bandel, 1972; Li, 1988; Mangotra \& Koul, 1991

16 Chennaveeraiah \& Patil, 1973

8 Sanjappa \& DasGupta, 1983

8 Sanjappa \& DasGupta, 1983

16 Kumari \& Bir, 1990

16 Mangotra \& Koul, 1991

16 Chennaveeraiah \& Patil, 1973; Gupta \& Gupta, 1978; Mangotra \& Koul, 1991

16 Li, 1988; Bairiganjan \& Patnaik, 1989; Mangotra \& Koul, 1991

32 Palomino \& Vázquez, 1991

16 Mangotra \& Koul, 1991

16 Mangotra \& Koul, 1991

16

16 Sanjappa \& DasGupta, 1983

16 Windler, 1974

816 Bandel, 1972; Bairiganjan \& Patnaik, 1989; Kumari \& Bir, 1990; Mangotra \& Koul, 1991

Sanjappa \& DasGupta, 1983

1632 Atchinson, 1950; Bandel, 1972; Bemardello et al., 1990; Palomino \& Vázquez, 1991 
APÊNDICE 1 - Revisão do número de cromossomos de espécies de Crotalaria, subdivididos dentro de suas respectivas seções e subseções botânicas.

\begin{tabular}{lcrl}
\hline Espécie & n & 2n & Referências \\
\hline C. pusilla & & 16 & Kumari \& Bir, 1990 \\
C. purshii & 16 & & Windler, 1974 \\
C. quercetorum & 16 & & Windler, 1974 \\
C. rotundifolia var. rotundifolia & 16 & & Windler, 1974 \\
C. rotundifolia var. vulgaris & 16 & & Windler, 1974 \\
C. sessiflora & & 16 & Kumari \& Bir, 1990 \\
C. shevaroyensis & 8 & 16 & Chennaveeraiah \& Patil, 1973; Patil, 1983 \\
C. tetragona & & 16 & Mangotra \& Koul, 1991 \\
C. usorensis & 8 & & Atchinson, 1950; Bandel, 1972 \\
C. valetonii & 8 & & Atchinson, 1950; Bandel, 1972 \\
C. walkeri & & 16 & Raina \&Verma, 1979; Mangotra \& Koul, 1991 \\
C. wightiana & & 16 & Chennaveeraiah \& Patil, 1973 \\
\hline 1 Banco de dados do Missouri Botanical Garden, Index To Plant Chromosome Numbers (IPCN).
\end{tabular}




\title{
APENDICE 2 - Trabalho publicado
}

\section{TÉCNICAS PARA A OBTENÇÃO DE PREPARAÇÕES CITOLÓGICAS COM ALTA FREQÜÊNCIA DE METÁFASES MITÓTICAS EM PLANTAS: PASSIFLORA (PASSIFLORACEAE) E CROTALARIA (LEGUMINOSAE)'}

\author{
Silvia Marina $\mathrm{Cuco}^{2}$ \\ Mateus Mondin ${ }^{2}$ \\ Maria Lúcia Cameiro Vieira ${ }^{2}$ \\ Margarida L. R. Aguiar-Perecin ${ }^{2.3}$
}

Recebido em 15/01/2001. Aceito em 12/12/2002

\begin{abstract}
RESUMO - (Técnicas para a obtenção de preparações citológicas com alta freqüência de metáfases mitóticas em plantas: Passiflora (Passifloraceae) e Crotalaria (Leguminosae)). Foram conduzidos experimentos visando à otimização de procedimentos para preparações citológicas de pontas de raiz com alta frequêencia de metáfases mitóticas, apresentando cromossomos com morfologia nítida, em espécies pertencentes a dois gêneros de plantas, Passiflora (Passifloraceae) e Crotalaria (Leguminosae). Para o acúmulo de metáfases, bem como de prófases e prometáfases com cromossomos bem condensados, foram avaliados pré-tratamentos de raizes, em que foram utilizadas diferentes combinações de 8-hidroxiquinolina, inibidor do fuso mitótico, com cicloheximida, inibidor da sintese protėica. As preparações foram coradas pelo método de Feulgen. Os melhores resultados foram obtidos com o tratamento com 8-hidroxiquinolina a 300ppm combinado com cicloheximida a 3,125ppm, por 1 hora e 30 minutos para as espécies de Passiflora, e a combinação de 8-hidroxiquinolina a 300ppm + cicloheximida a 6,25ppm também durante 1 hora e 30 minutos para as espécies de Crotalaria. Esta investigação ilustra a situação de dois gêneros de plantas em que a adequação de pré-tratamentos diferiu entre os grupos, e é fundamental para estudos envolvendo comparação do cariótipo das espécies, sobretudo para a deteç̧ão de marcadores cromossômicos evidenciados por meio de métodos diversos de citogenética (bandamento-C, bandamento com fluorocromos e hibridação in situ fluorescente).
\end{abstract}

Palavras-chave - Passiflora, Crotalaria, citogenética vegetal, cromossomos mitóticos, 8-hidroxiquinolina, cicloheximida

ABSTRACT - (Techniques to obtain cytological preparations with high frequency of mitotic metaphases in plants: Passiflora (Passifloraceae) and Crotalaria (Leguminosae)). Experiments were carried out aiming to optimize procedures for cytological preparations of root tips with high frequency of metaphase cells showing clear features of chromosome morphology, in species belonging to two genera of plants, Passiflora (Passifloraceae) and Crotalaria

1 Parte da Tese de Doutorado do segundo Autor

2 Departamento de Genética, Escola Superior de Agricultura "Luiz de Queiroz", Universidade de São Paulo, C. Postal 83, CEP 13400-970, Piracicaba, SP, Brasil

3 Autor para correspondência: mlrapere@carpa.ciagri.usp.br 
(Leguminosae). For the accumulation of metaphases, as well as prophases and prometaphases with well condensed chromosomes, pretreatments of root tips with different combinations of 8-hydroxiquinoline, a mitotic fuse inhibitor and with cycloheximide, a protein synthesis inhibitor, were evaluated in Feulgen stained preparations. The treatments with 8-hydroxiquinoline at 300ppm + cycloheximide at $3.125 \mathrm{ppm}$, and with 8-hydroxiquinoline at $300 \mathrm{ppm}+$ cycloheximide at $6.25 \mathrm{ppm}$, both for 1 hour and 30 minutes, were more effective respectively for Passiflora and Crotalaria species. This investigation illustrates a case of differences of pretreatment procedures between two genera of plants, as well as represents a basic work for studies involving the comparison of the karyotype of species belonging to these genera, and especially, for the detection of chromosome markers via several cytogenetic methods (C-banding, fluorescent-chromosome banding and in situ hybridization).

Key words - Passiflora, Crotalaria, plant cytogenetics, mitotic chromosomes, 8-hydroxiquinoline, cycloheximide

\section{Introdução}

Os procedimentos para preparações citológicas com alta freqüência de metáfases para a análise de cariótipos de plantas dependem do estabelecimento de uma rotina de obtenção de raizes apresentando meristemas com alto indice mitótico. Normalmente, sementes recémgerminadas são a melhor fonte de tais raizes, mas em casos de espécies que produzem sementes muito pequenas ou de difícil germinação, outros métodos de indução de raizes devem ser explorados, tais como enraizamento de estacas em vasos ou em meio de cultura. Outro aspecto altamente desejável é a obtenção de preparações com alta freqüência de metáfases apresentando cromossomos com morfologia nítida. Vários pré-tratamentos para acúmulo de metáfases têm sido descritos em plantas, tais como a combinação de agentes inibidores do fuso mitótico e da sintese protéica, bem como o emprego de hidroxiuréia para sincronização das células meristemáticas (Tlaskal 1980; Pan et al. 1993; Schubert et al. 1993; Schwarzacher et al. 1994; Silvarolla \& Aguiar-Perecin 1994; Lee et al. 1996; Bertão \& Aguiar-Perecin, 2002).

No presente trabalho, são relatados os resultados de experimentos conduzidos para a obtenção de preparações citológicas de ponta de raiz com alta freqüência de metáfases mitóticas, dentro de um programa de pesquisa visando o mapeamento de marcadores cromossômicos (via métodos de bandamento e de hibridação molecular in situ) em espécies pertencentes aos gêneros Passiflora (Passifloraceae) e Crotalaria (Leguminosae).

O gênero Crotalaria, pertencente à subfamília Papilionoideae, é constituido de aproximadamente 600 espécies, distribuidas principalmente nos trópicos, ocupando regiões de vegetação tipo savana ou cerrado (Polhill 1982). Embora tenha um grande número de espécies, algumas das quais importantes para a a gricultura, a análise citogenética do gênero restringiu-se apenas à contagem do número de cromossomos em poucas espécies (Gupta \& Gupta 1978; Raina \& Verma 1979) e à descrição do cariótipo de algumas delas (Palomino \& Vázquez 1991; Oliveira \& Aguiar-Perecin 1999). Nestes estudos, as raizes foram obtidas a partir de sementes recém-germinadas, ou de plântulas crescendo em vermiculita como substrato e pré-tratadas apenas com hidroxiquinolina.

O gênero Passiflora possui 465 espécies descritas (Vanderplank 1996), sendo algumas cultivadas devido às propriedades omamentais, nutricionais ou medicinais. $\mathrm{O}$ gênero é pouco estudado citologicamente e os trabalhos têm se limitado à contagem do número de cromossomos (Killip 1938; Storey, 1950; Snow e MacDougal 1993; De Melo et al. 2001).

Para o acúmulo de metáfases e prometáfases foram avaliados vários pré-tratamentos em que se utilizaram não somente hidroxiquinolina, inibidor do fuso mitótico, mas também combinações da mesma com cicloheximida, inibidor da síntese protéica. Com o emprego 
desses pré-tratamentos visou-se selecionar células com cromossomos pouco condensados em que pudessem ser melhor visualizados os marcadores cromossômicos a serem analisados por outras técnicas.

\section{Material e métodos}

Foram estudadas duas espécies de Passiflora ( $P$. edulis f. flavicarpa $\mathrm{e}$ $P$. amesthystina), da família Passifloraceae, uma espécie diplóide de Crotalaria ( $C$. juncea) e uma poliplóide (C. stipularia), da família Leguminosae. A Tab. 1 mostra os materiais analisados e os respectivos números de cromossomos relatados na literatura (Raina \& Verma 1979; Dornelas et al. 1995; Barbosa \& Vieira 1997; Oliveira \& Aguiar-Perecin 1999).
Sementes previamente escarificadas de Crotalaria foram germinadas em recipiente contendo Sphagnum umedecido, em sala climatizada a $28^{\circ} \mathrm{C}$. Ao atingirem tamanho aproximado de $1 \mathrm{~cm}$, as raizes foram cortadas $\mathrm{e}$ submetidas ao pré-tratamento com 8-hidroxiquinolina a $300 \mathrm{ppm}$ ou com combinações desta droga com diversas concentrações de cicloheximida, durante períodos de tempo variáveis (Tab. 1). Em seguida, as raízes foram transferidas para fixador de Carnoy (etanol:ácido acético 3:1), onde permaneceram por 12 horas à temperatura ambiente e posteriormente a $4^{\circ} \mathrm{C}$, até o momento de preparação das lâminas.

No caso de Passiflora, a obtenção de grande número de raizes para a rotina de trabalho foi mais eficiente a partir do cultivo de estacas de plantas matrizes, desenvolvido em telado. As

Tabela 1. Espécies de Passiflora (Passifloraceae) e Crotalaria (Leguminosae), respectivos números de cromossomos e pré-tratamentos utilizados.

Pré-tratamentos

Duração (horas)

P. edulis Sims. f. flavicarpa Deg. $(2 \mathrm{n}=2 \mathrm{x}=18)^{\circ}$

P. amethystina Mikan $(2 n=2 x=18)^{\circ}$

Hidroxiquinolina a $300 \mathrm{ppm} \quad 2: 00$

Hidroxiquinolina a $300 \mathrm{ppm} \quad 2: 30$

Hidroxiquinolina a $300 \mathrm{ppm} \quad 2: 45$

Hidroxiquinolina a 300ppm + Cicloheximida a 6,25ppm $\quad 2: 00$

Hidroxiquinolina a 300ppm + Cicloheximida a 6,25ppm $\quad 2: 30$

Hidroxiquinolina a $300 \mathrm{ppm}+$ Cicloheximida a 3,125ppm $\quad 1: 30$

Hidroxiquinolina a $300 \mathrm{ppm}+$ Cicloheximida a $3,125 \mathrm{ppm} \quad 2: 00$

Hidroxiquinolina a 300ppm + Cicloheximida a 3,125ppm

Hidroxiquinolina a 300ppm + Cicloheximida a 3,125ppm 2:40

Hidroxiquinolina a 300ppm + Cicloheximida a 3,125ppm 3:00

C. juncea L. $(2 \mathrm{n}=2 \mathrm{x}=16)^{*}$

Hidroxiquinolina a $300 \mathrm{ppm} \quad 2: 00$

Hidroxiquinolina a 300ppm + Cicloheximida a 12,5ppm $\quad 1: 30$

Hidroxiquinolina a $300 \mathrm{ppm}+$ Cicloheximida a $12,5 \mathrm{ppm} \quad 2: 00$

Hidroxiquinolina a 300ppm + Cicloheximida a $6,25 \mathrm{ppm} \quad 2: 00$

Hidroxiquinolina a 300ppm + Cicloheximida a 3,125pm $\quad 2: 00$

C. stipularia Desv. $(2 \mathrm{n}=4 \mathrm{x}=32)^{* *}$

Hidroxiquinolina a 300ppm + Cicloheximida a 6,25ppm $\quad 1: 30$

Hidroxiquinolina a 300ppm + Cicloheximida a 6,25ppm $\quad 2: 00$

* Número de cromossomos de acordo com Barbosa \& Vieira (1997) e De Melo et al. (2001).

* Número de cromossomos de acordo com Raina \& Verma (1979) e Oliveira \& Aguiar-Perecin (1999). 
estacas foram cultivadas em copos de plástico contendo o substrato Plantmax composto de vermiculita, turfa e cascas vegetais processadas e, após 15 a 20 dias, as primeiras raizes emergentes foram coletadas. Os pré-tratamentos utilizando 8-hidroxiquinolina e combinações com cicloheximida estão apresentados na Tab. 1.

Para a avaliação dos efeitos dos prétratamentos, as raizes foram coradas pelo método de Feulgen, de acordo com AguiarPerecin \& Vosa (1985), com algumas modificações. As raizes fixadas de Passiflora e Crotalaria foram hidrolisadas em $\mathrm{HCl} \mathrm{IN}$ a $60^{\circ} \mathrm{C}$ durante 12 e 8 minutos, respectivamente, lavadas em água destilada e coradas em reativo de Schiff por 45 minutos. Procedeu-se à nova lavagem em água destilada, seguida de maceração em solução enzimática composta de celulase a $2 \%$ e pectinase a $3 \%$, a $37^{\circ} \mathrm{C}$, durante 13 e 30 minutos, respectivamente, para Passiflora e Crotalaria. Após lavagem em tampão citrato (ácido cítrico $4 \mathrm{mM}+$ citrato trisódico $6 \mathrm{mM}$ ), as pontas das raizes foram esmagadas em carmin acético a $1 \%$. As laminulas foram removidas em nitrogênio liquido ou ácido acético a $45 \%$ e as lâminas então montadas em bálsamo do Canadá. As fotomicrografias dos cromossomos de Passiflora e de Crotalaria foram feitas em microscópio Axiophot 2 (Zeiss), utilizando-se o filme Kodak Technical Pan ISO 25 (Kodak).

\section{Resultados e discussāo}

Passiflora - Os pré-tratamentos descritos resultaram em acúmulo de metáfases, e as melhores preparações, com cromossomos bem espalhados, apresentando morfologia nítida, foram obtidas com a combinação de 8-hidroxiquinolina a $300 \mathrm{ppm}$ com cicloheximida a $3,125 \mathrm{ppm}$ por 1 hora e 30 minutos. A Fig. 1 mostra 0 aspecto geral de preparações feitas a partir de pontas de raiz de $P$. edulis f. flavicarpa submetidas a este pré-tratamento. Preparações das duas espécies de Passiflora mostraram o mesmo tipo de resposta a este tratamento, ou seja, grande número de metáfases com os cromossomos com grau de condensação adequado para análise de sua morfologia. As Figs. 2 e 3 apresentam metáfases de $P$. edulis $\mathrm{f}$. flavicarpa e $P$. amethystina onde se observam os cromossomos bem condensados e espalhados, visualizando-se claramente a presença de c onstrições secundárias e satélites nos pares de cromossomos 8 e 9 , os menores do cariótipo dessas espécies. Nas preparações de raizes tratadas apenas com 8-hidroxiquinolina, o bservou-se menor número de metáfases com o s cromossomos bem condensados, geralmente a presentando maior grau de sobreposição. Os tratamentos com duração maior que 1 hora e 30 minutos ou utilizando dose mais elevada de cicloheximida $(6,25 \mathrm{ppm})$ resultaram em alta contração dos cromossomos, o que dificulta sua análise morfológica.

Esses resultados foram importantes para o estabelecimento de uma rotina para a preparação de metáfases e prófases com cromossomos bem condensados, visando a analise de regiões organizadoras do nucléolo em experimentos de hibridização molecular fluorescente in situ, cujos resultados serão apresentados em outra publicação.

O efeito da 8-hidroxiquinolina e da cicloheximida tem sido explorado em diferentes espécies de plantas e o uso de concentrações e tempos de tratamento adequados é importante não somente para o acúmulo de metáfases, como também de prófases finais e prometáfases com cromossomos condensados, que também podem ser utilizadas para a análise de cariótipos. A superioridade do tratamento combinado das duas drogas pode ser compreendida de acordo com noções postuladas por Tlaskal (1980): a cicloheximida entra rapidamente nas células meristemáticas e inibe a mitose, impedindo o escape da metáfase para as fases subseqüentes; a cicloheximida causa supercontração dos cromossomos nas fases de prófase e metáfase; 


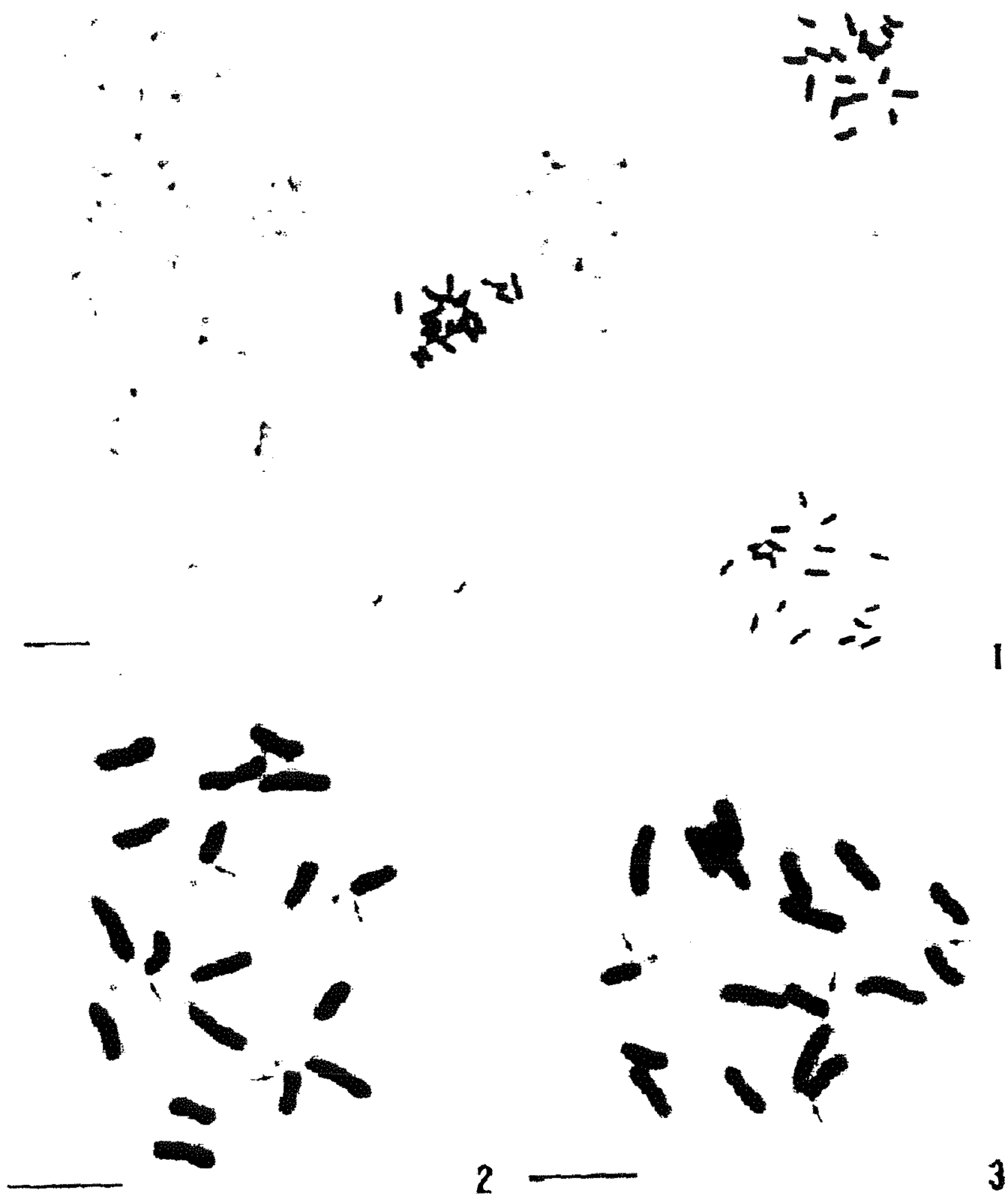

Figuras 1-3. 1. Acúmulo de células meta fásicas em meristema radicular de Passiflora edulis f. flavicarpa após tratamento com 8-hidroquinolina a $300 \mathrm{ppm}+$ cicloheximida a $3,125 \mathrm{ppm}$ por 1 hora e 30 minutos, e coloração pelo método de Feulgen. 2-3. Metáfases de Passiflora edulis e Passiflora amethystina, respectivamente, com $2 n=18$ cromossomos, apresentando dois pares de cromossomos com constrição secundária e satélite (setas). Barras de escala $=5 \mu \mathrm{m}$. 
a hidroxiquinolina quando entra na célula já afetada pela cicloheximida inibe o fuso mitótico e permite o espalhamento dos cromossomos durante o esmagamento; a 8-hidroxiquinolina contrai apenas os cromossomos metafásicos.

Crotalaria - Os pré-tratamentos de raizes avaliados entre as espécies de Crotalaria (Tab. 1) resultaram em acúmulo de metáfases, mas foi a combinação de 8-hidroxiquinolina a $300 \mathrm{ppm}+$ cicloheximida a $6,25 \mathrm{ppm}$, com duração de 1 hora e 30 minutos, a que induziu maior freqüência de metáfases apresentando cromossomos com morfologia nitida, como se vê na Fig. 4, que ilustra uma preparação de raiz de $C$. juncea submetida a este pré-tratmento. Em trabalho anterior (Oliveira \& Aguiar-Perecin, 1999), foi feita a análise do cariótipo de várias espécies de Crotalaria, a partir da observação de metáfases pré-tratadas com 8-hidroxiquinolina $0,002 \mathrm{M}$ por 4 horas e coradas pelo método de Feulgen, apresentando cromossomos com o mesmo grau de condensação e morfologia nitida, e em que a maioria das espécies apresentou uma constrição secundária no braço curto do cromossomo 1 . No presente trabalho, o pré-tratamento acima mencionado permitiu não somente o acúmulo de metáfases onde se vê claramente a posição do centrômero e da constrição secundária (Fig. 5), como também de prometáfases (Fig. 6) e prófases finais com cromossomos bem condensados e com morfologia nítida. Na Fig. 6, pode-se observar um dos cromossomos do par número $1 \mathrm{com}$ a constrição secundária muito distendida, aspecto este muito característico de prometáfases e prófases. As prometáfases podem ser distinguidas das metáfases pela presença das extremidades um pouco descondensadas, e as prófases com cromossomos condensados pela ação da cicloheximida, pela visualização do contorno do envoltório nuclear.

O tratamento com a combinação de 8-hidroxiquinolina a $300 \mathrm{ppm}+$ cicloheximida a $6,25 \mathrm{ppm}$ foi também eficiente para a análise dos cromossomos de C. stipularia, que são menores que os de $C$. juncea. A Fig. 7 mostra uma metáfase em que se podem distinguir claramente os centrômeros, a constrição secundária no braço curto do cromossomo 1 , bem como o tamanho menor dos cromossomos em relação aos de $C$. juncea. Esta diferença de tamanho já havia sido constatada por Oliveira \& Aguiar-Perecin (1999) e pode ser bem visualizada com o pré-tratamento empregado. Por outro lado, outros pré tratamentos utilizando a mesma combinação dos agentes citados mas com maior duração ( 2 horas) ou commaior dose de cicloheximida $(12,5 \mathrm{ppm})$ causaram maior acúmulo de metáfases e prometáfases com cromossomos muito condensados, em que a visualização de sua morfologia fica prejudicada. A Fig. 8 ilustra uma metáfase tratada com 8-hidroxiquinolina a 300ppm + cicloheximida a 6,25ppm, por 2 horas com os cromossomos muito contraidos e morfologia pouco nítida.

Os resultados deste trabalho sugerem que a combinação de 8-hidroxiquinolina a 300ppm + cicloheximida a 6,25ppm, durante 1 hora e 30 minutos é bastante adequada para um estudo comparativo de cariótipos de espécies de Crotalaria, sobretudo para a visualização de marcadores cromossômicos evidenciados através de métodos diversos de citogenética (bandamento-C, bandamento com fluorocromos e hibridação in situ fluorescente). A utilização de pré-tratamentos que induzem alto grau de contração dos cromossomos pode ser desejável em casos em que o objetivo seria apenas a contagem do número de cromossomos. A escolha do tipo de pré-tratamento é, portanto, dependente do tamanho dos cromossomos, que pode ser muito variável devido à grande diferença do conteúdo de DNA entre espécies de plantas (Bennett \& Leitch 1995; 1997). O presente trabalho ilustra a situação dos gêneros, Passiflora e Crotalaria, mostrando que os pré-tratamentos de maior eficiência diferem entre os dois grupos. 


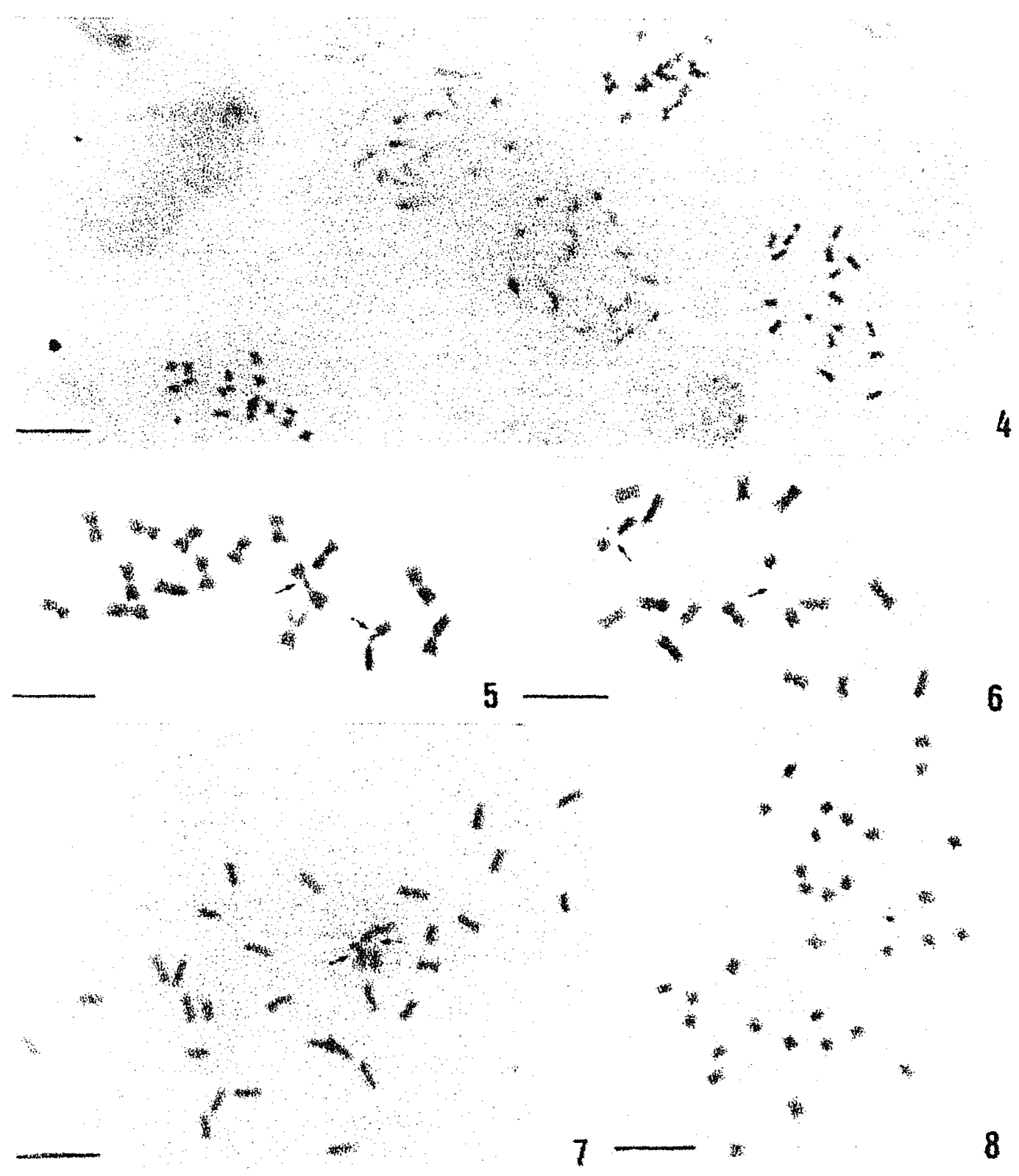

Figuras 4-8. 4. Acúmulo de células metafásicas em meristema radicular de Crotalaria juncea após tratamento com 8 -hidroxiquinolina a $300 \mathrm{ppm}+$ cicloheximida a $6,25 \mathrm{ppm}$ por 1 hora e 30 minutos, e coloração pelo método de Feulgen. 5-6. Respectivamente, metáfase e prometáfase condensada de Crolalaria juncea $(2 n=16)$, onde se pode observar uma constrição secundária na região proximal do braço curto do cromossomo 1; note-se a constrição muito distendida na prometáfase. 7-8 Metáfases de Crolalaria stipularia, respectivamente tratadas com 8-hidroxiquinolina a 300ppm + cicloheximida a $6,25 \mathrm{ppm}$ durante 1 hora e trinta minutos, e 2 horas. Note-se que a constrição secundária pode ser detectada na Fig. 7. Setas indicam as constrições secundárias. Barras de escala $=5 \mu \mathrm{m}$, exceto em (4) equivalente a $10 \mu \mathrm{m}$. 


\section{Agradecimentos}

Os autores agradecem à FAPESP, pelo apoio financeiro (Proc. 98/01170-5), bem como pelas bolsas de pós-doutorado (Proc. 99/07401-1) e doutorado (Proc. 01/06147-6).

\section{Referências bibliográficas}

Aguiar-Perecin, M. L. R. de \& Vosa, C. 1985. Cbanding in maize. Il. Identification of somatic chromosomes. Heredity 54: 37-42.

Barbosa, L.V. \& Vieira, M. L. C. 1997. Meiotic behavior of passion fruit somatic hybrids, Passiflora edul is f. flavicarpa Degener $+P$. amethystina Mikan. Euphytica 98: 121-127.

Bennett, M. D. \& Leitch, I. J. 1995. Nuclear amounts in Angiosperms. Annals of Botany 76: 113-176.

Bennett, M. D. \& Leitch, I. J. 1997. Nuclear amounts in Angiosperms - 583 new stimates. Annals of Botany 80: 169-196.

Bertão, M. R. \& Aguiar-Perecin, M. L. R. 2002. Maize somatic chromosome preparation: pretreatments and genotypes for obtention of high index of metaphase accumulation. Caryologia 55: 115-119.

De Melo, N. F.; Cervi, A. C. \& Guerra, M. 2001. Karyology and cytotaxonomy of the genus Passiflora L. (Passifloraceae). Plant Systematic and Evolution 226: 69-84.

Domelas, M. C.; Tavares, F. C. A.; Oliveira, J. C. \& Vieira, M. L. C. 1995. Plant regeneration from protoplast fusion in Passiflora spp. Plant Cell Reports 15: 106-110.

Gupta, R. \& Gupta, P. K. 1978. Karyotypic studies in the genus Crotalaria Linn. Cytologia 43: 357-369.

Killip, E. P. 1938. The American species of Passifloraceae. Publications of the Field Museum of Natural History, Botanical Series 19: 1-613.

Lee, J.; Arumuganathan, K.; Kaeppler, S. M.; Kaeppler, H. F. \& Papa, C. M. 1996. Cell synchronization and isolation of metaphases chromosomes from maize (Zea mays L.) root tips for flow cytometric analysis and sorting. Genome 39: 697-703.
Oliveira, A. L. P. C. \& Aguiar-Perecin, M. L. R. 1999. Karyotype evolution in the genus Crotalaria (Leguminosae). Cytologia 64: 165-174.

Palomino, G. \& Vázquez, R. 1991. Cytogenetic studies in mexican populations of species of Crotalaria (Leguminosae - Papilionoideae). Cytologia 56: 343-351.

Pan, W. H.; Houben, A. \& Schlegel, R. 1993. Highly effective cell synchronization in plant roots by hydroxyurea and amiprophos-metyl or colchicine. Genome 36: 387-390.

Polhill, R. M. 1982. Crotalaria in Africa and Madagascar. A. A. Balkeama, Roterdam.

Raina, S. N. \& Verma, R. C. 1979. Cytogenetics of Crotalaria I. Mitotic complements in twenty species of Crotalaria L. Cytologia 44: 365-375.

Schubert, I.; Dolezel, J.; Houben, A.; Scherthan, H. \& Wanner, G. 1993. Refined examination of plant metaphase chromosome structure at different levels made feasible by new isolation methods. Chromosoma 102: 96-101.

Schwarzacher, T.; Leitch, A. R. \& Heslop-Harrison, J. S. 1994. DNA: DNA in situ hybridization methods for light microscopy. Pp. 127-155. In: N. Harris \& K. J. Oparka (Eds.). Plant Cell Biology: A Practical Approach. Oxford University Press, Oxford.

Silvarolla, M. B. \& Aguiar-Perecin, M. L. R. 1994. Evaluation of chromosome numberstability in two sugarcane varieties. Brazilian Journal of Genetics 17: 237-242.

Snow, N. \& MacDougal, J. M. 1993. New chromosome reports in Passiflora (Passifloraceae). Systematic Botany 18: 261-273.

Storey, W. B. 1950. Chromosome numbers of some species of Passiflora occurring in Hawaii. Pacific Science 4: 37-42.

Tlaskal, J. 1980. Combined cycloheximide and 8hydroxyquinoline pretreatment for study of plant chromosomes. Stain Technology 54: 313-319.

Vanderplank, J. 1996. Passion flowers. 2 ed. The MIT, Cambridge. 